University of Louisville

ThinkIR: The University of Louisville's Institutional Repository

Electronic Theses and Dissertations

1945

\title{
Abstracts of source materials on the conservation of our natural resources.
}

Eunice Wheeler Duncan

University of Louisville

Follow this and additional works at: https://ir.library.louisville.edu/etd

Part of the Ecology and Evolutionary Biology Commons

\section{Recommended Citation}

Duncan, Eunice Wheeler, "Abstracts of source materials on the conservation of our natural resources." (1945). Electronic Theses and Dissertations. Paper 2047.

https://doi.org/10.18297/etd/2047

This Master's Thesis is brought to you for free and open access by ThinkIR: The University of Louisville's Institutional Repository. It has been accepted for inclusion in Electronic Theses and Dissertations by an authorized administrator of ThinkIR: The University of Louisville's Institutional Repository. This title appears here courtesy of the author, who has retained all other copyrights. For more information, please contact thinkir@louisville.edu. 


\section{UHE UNWvessir LIBRARIES}

This PDF document is a scanned copy of a paper manuscript housed in the University of Louisville (UofL) Libraries. The quality of this reproduction is greatly dependent upon the condition of the original paper copy. Indistinct print and poor quality illustrations are a direct reflection of the quality of materials that are available for scanning. The UofL Libraries greatly appreciates any better copies that can be made available for replacement scans. 
ane

Tite

jirector

Arrovez by: comittee

Surice meeier Durcan

Abstracts of cource atenials

on the conservation of our

atumal resources

1. A. jevies

Harvey B. Lovell

Austin Middleton

J. J. Oppenheimer Director

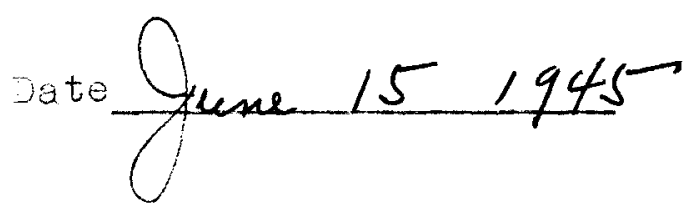




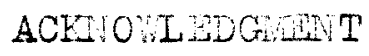

I wish to express ry deep apreciation to Dr. F. A. Davies for his guidance throughout the riting of this paper.

Junice Wheeler Duncan 


\section{WALA OE COHLTE}

I. Introduction................ I

11. Soil Conservation...............Page 5

111. Forest Conservation............. Fage 42

IV. hater Conservation...............eage 77

V. Milalife conservation.............

II. Mineral Conservation............. 140

nl. Tuman Conservation............... Fase 149

VIll. Wiscellaneous................Page 154 
I

IITRODTCTIOH

Conservation is a vest subject with many remifications, but it is a very concrete one. Though few of us realize it, conservation of our natural resources -both humen and material--touches ali of us. In the lack or gbundance of our food, in the price we pay for our clothes, in the availebility of our utilities, in the Iuxury or poverty of our homes, in our personal and communty health--in all these and many more ways, : are affected. Our naturel resources are important not only to the conservator and the exploiter, but to evory nan and woman in Arerica, and to the chiluren who will inherit the land.

Until the tine of wheodore noosevelt there vere prectically no conservation practices and very little material wes pubished on the subject in arerica. As Eresident, and ith the assistance of viford inchot, Theodore noosevelt called a meeting of all state and territorial zovernors for the purpose of working out some plan for conserving our country's naturel resources. This thite louse Conference of Covernors took place in 1908. Though much erthusiasm was aroused, tangible and far-reaching results vere $\hat{i} \in$. 3. the early 1...' is the Cederal Goverme nt began 
to study land-use and water problens in the United states. Conservation programs and projects followed rather rapidy. In 1933 the Tennessee Valley duthority was created, the Civilian Conservation Corps was established and the boil Brosion Service (now called the soil Conservation Service) vas organized. The Tennessee Valley futhority was the first national experinent in regional resource deviopment ana conservation. The Civilian Conservation corps eneaged in extensive national park reforestation and other conservation rork. The objective of the soil conservation service is to propagate the use of soil-conservation practices in agriculture. In 1954 the lational Resources Board (since 1029 called the National Resurces Flanning Bogrd) was created and made the first national survey of land-use conaitions in the United states. otier importent governmental aencies, appropriations, acts, and projects have followed since that date. Slowly the states began to plan conservetion proprans. Now rorty-five states have conservation departments, and all states and outlyine territorial possessions have some type plan and agencies to mork on their particular conservation problems. Many interstate compacts have been formed to care for projects which overlap state boundaries. other agencies and orgenizations have furthered 
the cause of conservation. Amone these are the american Forestry Association, the Izaak falton League of Arerica, the Carden olub of America, the rational Associstion of Aubuon Gocieties, the ild flower Fresenvation society, the American fildife Institute, the "ildife Federation and nany othors. Nany civic clubs and women'a ongenizations throughout the country are also interested in conservation.

All these agencies--the paderal covernment, state covernments, clubs, organizations, anà indiviauals have published an extensive amount of rich study material within tre last decade. Wuch of the naterial has been in the form of bulletins, phamplets, reports, studies, and investigations. Because of the newness and conpiexities of the subject a miter usually confines his work to one fiela in conservation.

rost of the material is on an adult level. It is only recently that educstors have begun to integrate conservation in the curriculur. There is still much controversy as to how conservation should be treated-whether as a separate subject or as an integrated part of the subjects already established in the curriculun. Some other problens in the educational field are those of teacher training, organization of material and the scarcity of reading meterial at elenentary and junior high school level. 
This study has been made uith the objective of conpiling all the reading material possible on conservation. This material has been summarized in such a manner as to include the inportant data on conservetion and it's place, level, and possible ase in curricular prosers. Books, bulletins, phamplets, reports, magaine articles and other types of material have been abstracted. All phases of conservation have been considered--soil, forests, water, winerale, wilipe, and human resources.

lo the best of my knowledge this is the most recent copilation of conservation naterial. To me it has already been of invaluable aia in oreenizing my own source naterials in the curriculun. I trust that it ney serve other teachers and interested persons in a like manner. 
SOII RESOURCES

A Bulletin on Conservation of Natural Resources, State Department of Education, Division of Public Instruction, Denver, Colorado. Undated. $136 \mathrm{p}$. 11lus.

This bulletin gives a clear picture of the history of land use in Colorado from the time of the cliff dwellers through the buffalo people, the explorers, the hunters and traprers who made no excessive demands upon the land, through the cattlemen and farmers who made a business based on the richness of the earth. The stock raisers injured and depleted the grass; then the farmers plowed it up. The resulting erosion by winds and rains has: created many problems. Each successive wave of settlement in Colorado was either a result of a boom period sonewhere else or in soneway connected with a pattern of life in which buying and selling had become a dominant factor.

A survey of Colorado's land resources is presented. The rivers, land formetions, climate, soils and native vestation and wild life are discussed. The correlation between the erratic and limited rainfall, wide variation in growing seasons, irrigation problems and agriculture are shown. The behavior of soil and water and man's influence are clearly defined.

Solutions to Colorado's problems are being aided through agencies such as the state College of Agriculture, State Ingineer's Office, Yater Conservation Board, Soll Prosion Districts, United States Forest Service, United States Grazing Service, United States Soil Conservation 
Service and others. A description of how a soil conservation District works is given.

Realizing that education is an important factor in approaching the solution to any problem, this bulletin has been published for the use of teachers. The material is excellent basic or source information necessary in an undestanding of land problems and the efrects of nisuse of land resources.

\section{A Tentative, Bugrestive Special Unit on Tasington istory,} Washington Department of Fublic Instruction, Olymia, September 1941. $26 \mathrm{p}$.

This unit, to be used in American history classes, on a junior high school level, integrates conservation of the soil and water under the topic "farm problems." Attempts to solve these conservation problems include farners' cooperatives, and projects of the Federal Government. Another appropriate place to study conservation problems would be in relation to the luber and fish iraustries in ashington. Wost of this unit is concernea with the political history and developnent of this state, yet conservation has been outlined in one section, and other opportunities are usable.

This unit gives a fairly good example of how conservation can be integrated with history.

Adrift on the Land, Taylor, Faul S. Public Afiairs Comittee, Sew Tork. 1940. 62 p. illus: Fhamplet io. 42.

svery year irok one to two milion men, women and chilaren move about the country seeking farm jobs. Nost of these 
follow the crops from one section to another, finally returning to their homes.

Wheat caused the greatest trek of farm labor from 1900 to about 1950. Cotton too caused migration, particularly, in the southest. Ifechanization in the form of combines, Ginning machines and pickers has caused a decline in these migrations. Berry crops which require a large number of skilled hand pickers have long been a cause of seasonal migration. Usually the distance covered by these migrants is not great. Sugar beet workers move only twice a year. On the Test coast roving field hands follow the harvests of fruits and vegetables. California and Arizona agriculture have been torn by freouent strikes and disputes. These conflicts aiffer from ordinary farm labor di sputes because of (1) industrialized agriculture, (2) desire of employers for complete control of ases as aistinct from other costs, (3) perishability of crops, (4) lack of status of mobile workers in agriculture, (5) interstate mieration. The problems relating to migratory 1 abor in California should not be considered as local or isoleted. In a sense, it may be that the situation in that state provides a "pre-viem" of whet will occur in varying degrees and in modified forms on a national scale.

The farm problem is becoming a problem of the relation of people to the land on which they work, and not a problem of price alone. This phamplet is a vivid description of our migratory agricultural labor and its problems; no attempt is made to solve these problems. It aids in the understanding of the situation. Frogressive citizens should read it with keen interest. 
Agriculture, (fon-vocational Course of Study for crades ine and Ten), Iowa Department of Fublic Instruction, Des roines. 1940. $153 \mathrm{p}$

Seven units on ariculture stress the problems relating to Iowa. Wuch use is nade of community environment. The units deal with sociel and economic phases of agriculture as it influences farm and city dwellers. The economic fiactors include ownership, tenarcy, credit, labor, prices, end aericultural surpluses. Jodern practices for efficient production of livestock and crops are talen un. Gome thouent is

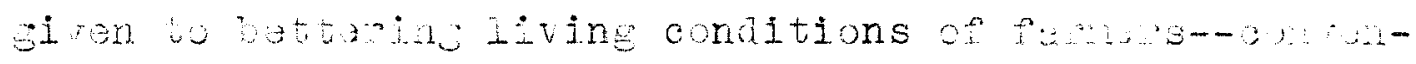
I: 10es, housing, equipment, etc. The unit on conservation of farm lana is concerned rith rotation of crops, use of fertlizers, contour plowing, crops thet return certain el mments to the land, and help received through working ith county agonts.

The units are worked out as problems acconpanied by questions to be used in preparation for discussion. 'These questions are thought-provoking. The neakness of the units lies in the lack of creative and activity work--no suggestions for excursions, experiments, visual aicis, etc. are given. Since these units are of most use in rural community schools, oportunity for such activity should be provided. References, most of which are free, are adequate and up-todate.

For the use of teachers, the units are bases for undarstanding agriculture and its problems, but suplementary aditions are needed.

Conservationist in Iexico, Leopola, Aldo; American Forests. 
March 1987. po. 118-120 illus.

cur southwestern mountains are now bady gutted by erosion, whereas the sierra Madre rane across the line still retains the virein stability of its soils and ell the natural beauty that goes with that enviable condition. It is ironical that Chihuahua, with a history and a terrain so strikingly similar to Southern New liexico and Arizona should present so lovely a picture of ecological health, whereas our own states are so bady damaged. However, this contrast holds good only for the mountains. The lov country on both sides of the boundary has been equally abused and spoiled. The Sierras escaped because of the mutual fear and hetred between the rexicans and Apaches; they were never settled, never srazed, hence never eroded. The Chinuahua Sierras have been grazed only neer the Hormon colonies, but these colonies are microscopic when compared with the bulk of the mountain resion.

Very recently the Mexicen Resettlement Administration hes scattered landless voters over many a non-irrigable mountain valley. Inevitable ruin will follow, but as yet these resettlements are very small when conpared to the mountain area. The sierras present an example of abunant ame pooulation; a normal complement of predators is present. Wany loose-mesonry dans are found in the sierras-built by prehistoric Indians. These little dams were built to create Iittle fielas or food patches.

The tourist-promotion policy of the Rexican government of rosd-builaing plus setting of the mountain valleys will increase crazing; the end result vill be bad unless hexico 
aoes a better job oi srazing regulation than the United States has done.

Whis article aims to explain why the sierra kadre range is an example of unspoiled mountain landscape, and to pilosophize on the irony of it. Interestingly vitten, it is for adult reading.

Conservation of Lends and ater, A Tesching Unit, Santa Cruz School, Abuquerque, Nev rexico, Curriculum Iabretory, university of New Mexico. May 1938. 31 p. mimeo.

This unit uses the environment of the eroup as subject matter. Iivine in the Santa Cruz Valley, their families furmers, the children's interests are closely reluted to lend use. They had witnessed rloods; they had seen cattle aie from lack of feed; they had seen parts of their father's fields washed anay; they were naturally interested in why water, which is so destructive, was necessary, where it carne from and how it could be controlled. Their activities (maps, excursions, experiments, sand table building, weather charts, stories and songs) were rich and varied. The knowledges and attitudes gained were ones that they could use in their daily lives. The unit must have been a very neaningiul experience to these chilaren.

No teacher could or would care to carry out exactly this same unit, but it gives definite help in how to carry out such a unit in any community. This unit, used in a second erade, gives good ideas for studying your onn conmunity. The activities can be adapted to the indiviaual situation. The bibliorraphy would be helpful to any study of conservation of land and water. 
Deserts on the March, Sears, Paul B. University of Oklahoma Press, Norman. 1935. 231 p.

Nature has a certain botanical or biological balance, which the abuse and ignorant use by man sometimes disrupts. Men destroy soil through unwise use, ana the soil becones a desert. The effects of destroying the forests, over grazing, plowing up great areas of grasslands, overcropping and cultivation and the resulting deserts of sand and just, floods, stamplands, erosion, droughts, and pests (insects, rodents, disease) are discussed in detail. The socialeconomic implications for people in all regions--eroded, flooded, and dust scarred--are discussed. The way out of such a wasteful and unproductive state is a great task; there is no one soverien remedy, but a conbination of methods must be employed--methods which may be skillfully adjusted to the particular situetion. Longtine planning, and in some instances, governinent control is necessary. The situation is presented in nontechnical language, always simple, and often dramatic and witty. This book deserves a host of readers and is highly recommended for scientist and layman, educator and statesman, farmer and city dmeller, for it is a timely and solemn warning against greed and expediency, lest the history of our continent become a chronicle of deserts on the march.

Farmers ithout Land, Vance, Rupert B. Public Iffairs Comnittee, New York City. 1967. No. 12. 51 p.

There has always existed in America a strong belief in the values of term ownership. Yet since 1880 there has been an increasing rate of tenancy in the united states. The de- 
pression has not lessened the problem of insecurity on the land. Left to itself, tenancy seens bound to increase until it affects more than half our farms. The most able attemot to rationalize the system is found in the agricultural ladder theory aeveloped by w. J. Spiliman.

Stable ownership and security of tenure are definitely rel ted to good practices in growing of crops, in the control of erosion, and in the care of buildings and property. As it is hopeless to throw the responsibility for conserving the land on farm tenants, it is also too much to hope thet they ail support a healthy commity life. on church and on school, farm tenancy lays a heavy hand.

In the great Cotton Belt, farm tenancy is but one phase of a complex situation. The link between tenancy and cotton production is close. Race enters the picture as another important element. In a recent study made by the w.P.A. it was found that the typical plantation was occupiea by the landord and fourteen aditional families: three mage hands, eight croppers, two shgre tenants, one renter. The task of the lendord requires skill and energy. Tet many plantation landomers were not full-time famers--31\% spent more than $1 / 4$ of their tine at other occupations. Low incone, poor housing, poor diets, inadequate medical and health services, few educational opportunities-- these are the tenant's lot. Whe President's fenancy Comittee in 19.00 shoved the need for a National program to work out this complete situation. This phamplet deals with all phases of the tenancy problem, and sote of those affected on the landomer. ritten on a senior high level, it discusses one of the big 
problems related to our agricultural program.

Fields in Finter, Cornell Rural School Leaflet, New Tork State College of Agriculture, Cornell University, Ithaca. Vol 43 , No. 3. January 1940. 32 p. illus.

Snow banks are important to wildife--as warm homes for some enimals, and as loss of food for other animals. whe run-off of snow ana ice in relation to plant prowth is aiscussed. Flants are imortant as shelter and pood for game. Fence rows and rockpiles in winter help form snow drifts, thus proviaing shelter for many animals. Need patches and road cuts serve a purpose--that of sheltering wilalife. Animals cannot find protection in heated homes, but the snow makes warm shelter for them. on cold days it is warmer under the snow than on top of it. Grouse, squirrels, and other animals seek protection und $r$ the snow. Tracks one may observe in the snow are described.

The discussion stresses the problems of open fields in minter, and wildife. Wildife is considered as having definite money value and much economic use is discussed. The activities are rather limited, but wi th such material, that is to be expected. The cartoons present ideas necessary for understanding the management of open spaces in winter for wildife. The are clever and upper elementary and junior high students ill appreciste them. Wuch of the material can be read by fifth and sixth grades.

Garlening for Food and Fun, (Conservation Week in liew Jersey Schools, 1941), New Jersey State Conservation Committee, Trenton. $15 \mathrm{p}$. illus. 
Gardening is an interesting experience. It is nost Ijicly to be an educetive experience when it is cerried out under the guidance of a teacher who can utilize the garden as a necessary labratory for teaching science. It provides firsthand contact ith natural things. It teaches the dependence of man end other aningl life on plant lite. The school earden site need not be large, but every earden should be planned in detail. Soil must be considered, as well as tools, care, and vacation plan of care. Wxhibits, canning and preserving are excellent activities. Animel frienas (biras, toads, snakes, earthworns, etc.) as well as enemies are considered.

This leaflet is excellent, for teacher use, where focilities are such that schools can have gardens, either vegetable or flower. The activities are nany and varied; chilaren get great satisfaction from them; many phases of nature study enter the picture. The bibliography is excelient.

Holes in the Ground, Cornell Fural School Leaflet, New York State College of Agriculture, Cornell University, Ithaca. Vol 55, ro. 2. Novernber 1941. 31 p. illus.

soil is in different layers. The turf layer is a loose layer at the top where the soil and plant parts are mixed. The next is the topsoil--valuable ror rowing plants. Beneath the topsoil is the subsoil, witch slowly becoines topsoil. In a forest the looseleaf-covering of the soil is called aff or forest litter. Duff is full of holes unless the legves are firmly pecked. Many aninels burrow through it. Mice, molas, woodchucks, grasshoppers, ants 
and worms make holes in the soil. These holes let in air and vater ond help to form topsoil. A valuable digger must aif many holes; it must bring soil from beneath to the surface; it nust not destroy the plants we wish to grow; the earthworm meets all these requirements.

Plants make holes in the eround when they sprout. Shallow rooted plants as well as aeep rooted ones hold the Eround particles from ashing. Legumes such as alfalfa, peas, beans, clover, etc. take nitrogen from the air and use it to meke plant tooà that is excellent. Small holes, which cen be seen with a hanà lens, are very important. These are made by nematodes and protozoa. Air and water are very important in the soil. Irosion is less severe if plants, earthworns, and other snimals heve provided enough holes, for less water is lost. Farmers may check erosion by contour plowing, rotation of crops, planting cover crops and not overgrazing or burning over the land.

This leaflet explains the make-up of soil, and factors influencing makin topsoil; how farmers can make vise use of their land. Farts could be used by classes above the fourth grade. The illustrations and diagrans are excellent.

\section{Iand Use and Soil Conservation, Informational Waterial} Available to the Public), United states Department of Agriculture, Soil Conservation Service, Washington. 1940. 7 p.

Listed are: (1) Publications on (a) The Soil Conservation Service, (b) General Farm Fractices, (c) Primery Regional Interest (Northeastern, Southeastern, Ohio Valley, Western Gulf, Upper Kississippi Valley, etc.l. Given are title, date, pages, price and where to order. (2) Naps of erosion 
and lend surveys, Aveilable to fermes, agrioulturs work-

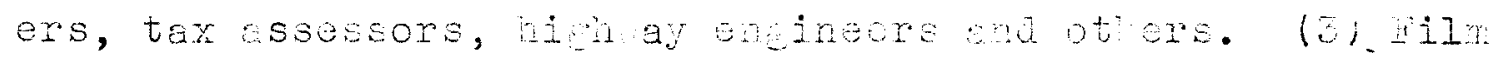
strips-title, price and where to oraer loan be wanted, norowed or purchesed). (4) Jacarine--soil conservation - $10 \%$ a cony or "1.00 a year. (5) tovieg--16 me sound-aveileble

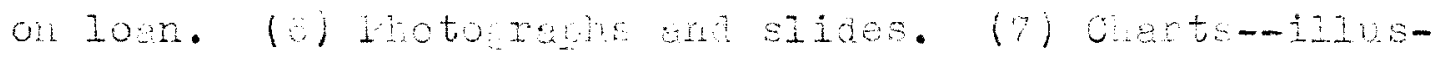

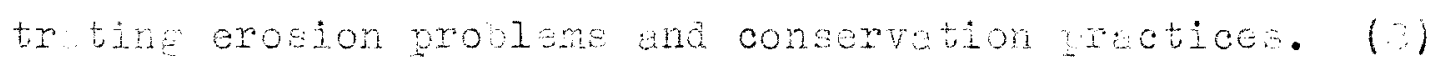

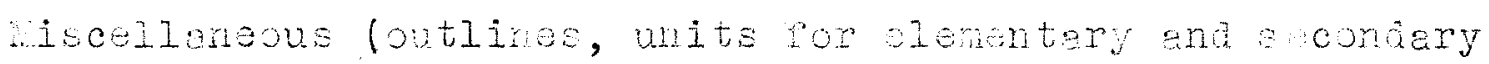
conools).

Uvery person interesed in conservetion should have

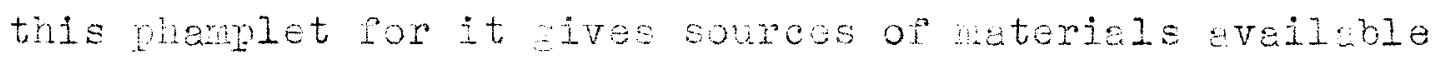
throun the soil conservetion bervice.

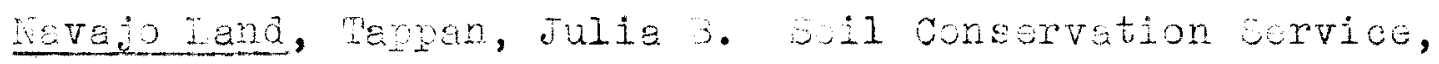
Division of Lacetion, Luquerque, lien texico. 1969. $11 \mathrm{p} \cdot \mathrm{nineo}$

This dialogue beteen on old nen lomenting the ate of land, and a youne agn telling in now it on be restored, would be of interest to fourti, eifth, or sixth greae children. It tells hat has caused the land to be rerrer leter, Hibs, over rapirej. It sloo tells of ave to brine it beck to health oy rosting the land, plentine to gress, lixitine grazing, ams, etc.

ritten in the style of the poom "iavatha, cinldren mould like it.

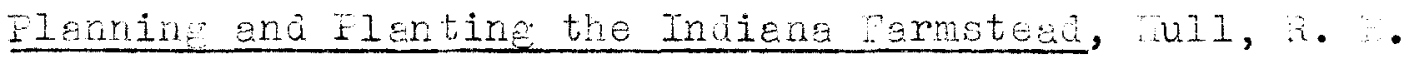
Fuwae university, Departocnt of erojoulturel artension, Lafayette. Bulletin 178. ray 103l. 05 p. illus.

The Iniana farm sanily has nany advantages in favor of 
a fine development of the farmstead. Space, surroutiding country, good soil, and native trees and shrubs all play a large part in planning a pleasant living place. Proper development of the farmstead requires time ano planning. The location of the dwelling, area around the house, the barnyard, alks and drives should be considered in any such planning. Suggestions $a s$ to where to place trees, shrubs, and vines, and the best kinds to use are given.

Fractically all farm families ore interested in improvement of the farmstead, both from the standpoint of increasine the pleasures of country living and thet of enhancing the real estate value of the farm. This bulletin would be very helpful to farmers in Indiana and surrounding areas, and to city dwellers because it eives native trees, shrubs, vines, and flowers which may be hed tor the labor of collecting and planting them.

Fublic Land Acquisition, Fart 1 Rural Lands; National Resources Planning Board, Land Committee; Government Printing Oftice, lashington. June 1840. $24 \mathrm{p}$.

The central aim of the national land policy is to enable man to derive from the land the maximum benefit end satisfaction consistent with the permanent maintenance of that resource. Accompanying these beneits there heve been a number of undersireble effects, such as a great wastage or soil and tirber, and the development of excessive tenancy and rural sluns. Land acuisition has today become one instrument, and a basic one, among many for the effective conservation development and wise use of the nation's resources. In keeping ith the American iueal of private ownership, public 
policy limits land acquisition to the scale necessary for acconplishing dêtnitely planned lana-use prograns. Objectives of such a jrogram are the preservation and development of resources (soil, forests, coal), preservation and rehabilitation of humen resources, reduction of expenditures for public services and relief, provision of sites for public buildings, preservation of scenic, historical, and scientific sites. Fublic benerits should be considered not only in terrs of airect money returns, but also in terms of comunity values (not always precisely determinate), in terms of huran values and their contributions, in terns of savings in public funds, and in regional or national terms. Folicies guiding this program are Inds now in private ownership. (managed on a conservation basis), which are not profitable, Ianas which constitute a serious hazard to surrounaing areas, lands that are operated (privately) profitably only through rapid depletion of productivity, and lands necessary for certain projects. Iand-use procrams involving lend acquisition are National Farks, conservation of forests and protection of watersheds, conservation of mildife, and purchases for Injians. Land ac uisition frequently results in some population movement. The aministrative asency has some responsibility for aiane the people who must more to become favorably reestablished. Factors affecting the character and extent of this responsibility are the rate at which the movement nust be accomplished and the degree of assistence required.

This report clearly states the objectives of land acquisition by evernmental agencies, the sucial and economic 
aspects involved, and the uses to which the acuired lands are put. The report is intended for the National resources Flanning Eoard for inclusion in its public works programs and projects, but for the interested reader it eives a clear picture of what sovernmental acencies vian to do ith acquired lands.

Public Lana Accuisition, Part 2 : Urban Lands, National Resources Flanning Board, Iand Comittee; Government Frinting oftice, Gashington. Pebruary 1941. $56 \mathrm{p}$.

Whe basic melajustment benind most urban land probiens today lies in the irrationality of urban patterns. It had been assumed that urban erowth would continue indefinitely, and that expansion and booming of land values would, in time, introduce order and correct errors of the past. Around the core of most Anerican cities today, there is an area of declining housing and marginal business, and area losing population and value, an area obsolescine both as to locetion and function. This is called a blichted area. At the other end of the urban raius cities have been plasued periodically with epidenics of wilacat speculation and premeture subdivisions. lieh municipal overhesi and tax delinguency are other indicators of "subrarginality" of urban land. Types of control now in use in zoning, control of subdivisions and plats, building and plumbing codes, subsidies and inducenents, taxes, and public ownership (one of the most promising mothods). The principal objectives served by public land acguisition are sites for public buildings and enterprises, and for lana-use control. Land is accuired by purchase, condemntion, tax reversion, mortage foreciosure, ift, exchange, lone-term lease, 
and reclanation. Fiscal, economic, and administrative requirements are many and complex. Land plannin and acquisition will be called upon to play a larger role in the city in the future.

lhis report on urban lanas is a conprehensive treatnent of the problems of urben land acquisition. It is concerned with the round-work for the formulation of useful and flexible tools for urben land planning. It emphasizes the need for coordinating units within the Federal Government with city agencies concerned wi th effective redevelopnent of our cities. It is especially planned for use by cities in adjusting their existing problems and needs.

Rich Iand, Poor Land, Chase, Stuart; thittlesey House, New York. 1926. 352 p. illus.

The North American continent before the coming of the white man was rich in growing thines, incredioly beautiful, and perheps one of the most bountifully endowed of all the continents. Forests, grasses, and wildife were at the maximum of their vitality; deserts were at a minimum. In soo years we find this continent vastly changed. The old forests ana grasslanas heve almost conpletely disappeared; deserts have broadened; continental soil is visibly and rapidly declining; forest cover has been stripped, burned and steadily shrinks; rain and snow rush to rivers; floods and aroughts goow worse; wildife is rapialy declining; minerals have been depleted. If such devastation continues at the sane rate in the ruture there can be only one end. Te must decide whether we can keep an advanced technology and yet come to terms with nature. An equilibrium must be 
detemined and it must be planned. America has reached its relatively high standsrd of living on its resource capital. The various resource areas and what has happaned are under the captions (1) croplends, (2) grasslands, (3) forest-lands, (4) watersheds, (5) wildife, and (6) minerals. To meet the problems we must plan. The TVA is the first comprehensive procram of planning with nature ever attempted in the United states. Te need more regional plannine. Theodore Roosevelt started the conservation movenent. F. D. Roosevelt gave new impetus as evidenced by activities of the C.C.C., Soil Conservation Service, etc. America has reached maturity in business. Fublic works and services can use the surplus labor. But we must convince the people of the need and rightness of this.

This survey of America's natural resources rakes facts and figures vital and drematic. It is as interesting and readable as a novel. In spite of the discouraging story it tells, it is definitely one that all shoula know. Iriten for the laynan, it should be rejuired reading for all colleges, clubs and adult organizations to acauaint them with conservation and whet is needed.

Save the Soll, Cornell Rural School Leaflet, New York State College of Aericulture, Cornell University, Ithaca. Vol. 29 , 10. 4. March 1936. 32 p. illus.

The physical nature of soil, the slope of the land, the cuentity of rain and wen it falls, the distribution of vater through the soil, wind, tempersture, soil cover, and uses made of the soil all enter into problems of conservition. pine particles of soil are more easily ashod avay than 
are larger particles. Slope and cultivation up and down hill cause great soil loss. In a humia climete, such as New York's, Ereatest soil loss is through washing by water. About four months of the yoar in New York the ground is frozen, and little soil is lost. The speed with which vater moves determines the damese done. Flants do much to hold soil. They resist the action of wind, water, and help hold the water which falls. This is true of forests and grasslands. Flants along roadsije benke prevent ashing; this is gooc economy because of the expense of keeping roeds. Nuch steep land which has been cleared should be returned to forests, not only for lumber, but for control of erosion and to regulate stregm flow. Burdened by taxes and other expenses, famers are forced to obtain frow the soil all the immediate returns they can. However, fertility cannot be meintained if soils are exhausted by unwise use and by erosion.

This leaflet is primarily for teacher use, but ports could be used by fupils above the fourth grade. The material helps one understand the unaerlying principles of conservation, and sone of the Federal and state programs for conserving soil. Experiments for measuring run-oif in various kinas of soil, use of a rair guage, and measuring land slope are given.

Saving our Soil, Stewart, haxwell s.; Fublic Affairs Comittee, Inc.; ew Tork City. Lo. 14. 1957. $1 \mathrm{p}$.

Three centuries ago, North America was a virgin continent. Its wealth seemed inexhaustible. Poday, many of these riches are sreatly reducea. The depletion of the soil, and to a lesser extent, the destructiveness of floods, are indirect 
results of man's activities. Frosion is caused by ater and mind.

ie cannot replace the tons of fertile top soil which have been washed into the ocean. Mor can wholy stop the natural process of erosion. It is within our pover to rejuce these losses to moderate proportions. Ihe soil Consorvation Service is conductine 174 demonstration projects in 40 states to ive famers aid in conservation practices. Pe National Resources Board has surveyed the problem and hade susgestions with regard to the broad policies which the country should adopt. The immediate responsibility lies in the hands of milions of individual farmers. The suggestions to these farmers include a planned farm, grass crops, rotation of crops, contour tillage and terracing, strip croppin, and winter cover for all fields. Reforestation on a large scale is primarily for the state end nationel Eovernnent rather than the individual.

control of erosion is an important means of preventing floods. Check-dans, ponds, reservoirs, sumps and marshes, upstream control by dams and levees are neans of conserving our water resources.

A national program of control for erosion and floods is needed. Some objectives have already been pertially carried out, but we have not yet begun to meet the challenge of erosion.

Mis report aiscusses, in sinple and interesting form, the various causes of erosion, methods of control anu what has been done up to 1957. It is excelient meterial and perts can be used as a textbook by sone sixth graders, and junior 
hieh school students.

Soll and IIdifife Conservation, Le Compte, t. Lee, Conservation Depertment, Gane Division, Baltimore Varyland. April 5 , 1938. $5 \mathrm{p}$

cononic as vell as sosthetic factors are concerned in the conservation of our illife. Soll exosion has aestroyed thousands of acres of land. Te plentine of legunes and Erasses on slopes as well as botton land areas helps to prevent erosion. Wany woody plants are valuble in checking erosion. Mnd, these plants--krasses, legumes, trees, and shrubs provide food for vilalife. The more biras a farmer attracts to his property, the less aificulty he has in Eroung crops, as the majority of biras are beneficial to the farm interest in destroyine obnoxious veeds, seeds and insects. Cited are the foods eaten by bobmite, robin, meadow lark, king bird, purple martin, and others which are beneficial to the former.

This adaress, given over the radio, endeavors to show the fermer some of the benefits he receives when he aids wililife by leaving fence-rows in crowth, and plants food end manages his modlots so that willife can exist. It is convincing, as far as it goes, but fils to consider some of the problems of the farmer (veed control, hunters, etc.).

Soll Conservetion, Bennett, Wueh il.; McGraw-iil Book Cmpany, New York. 1959. 958 p. illus.

Surveys made in 1964 showed thet 50 million acres of cropland in the United states vere virtually useless; another 150 milizon acres of arable land has declined far enough to 
nake farming unprofitable. The combination of dashing rains and vest acreages ir croplands mikes the United states susceptible to erosion. Hrosion inpoverishes not only the land but those who Iive on the land, and areas dependent upon the welfare of the Pamer. later erosion is conditioned by factors of slope, soil type, land use, and amount and intensity of rainfall. "ind orosion is an acute problem in areas of 10w reinfell. A dense cover of vegetation is the most powerful practical meapon known for reducing erosion and run-off. In planning suitable soil conserving practices, all phases of the general problem must be analyzed from the climatic view-point. Mass movement and insect population are important indirect causes of erosion. Methods for increasing infiltration are cultivation, vegetative cover, ading oreanic matter, contouring, terracing, and strip croppins. The basic principles of close growing vegetetion effective in checking soil and ater losses are (I) reduces direct imract of rain on soil surface, (2) speed of run-of is checked, (3) organic matter increase improves water-holding capacity. Grasses and leguninous plants sujtable for erosional control are listed. Porests and their mangement have a definite place in soil and water conservation. GuIly control, hiehwy erosion, stream banks, and related topics are fully aiscussed. Mildifie managment and soil conservation are closely related; the benefits are reciprocal. IrobIens peculiar to verious areas and efforts to control and reduce erosion ere described. Frosion problems in foreign countries are being met in various ays.

Throughout this very detailed account one is impressed 
by the many fielas into mich lana problems reach. The exosion procese, the physical, economic, social, and hunon belfare aspects of the problem, the techniques, plans, and programs for soil and wer conservation, and the results obtained are of vital importance, we wit the soil conservetion cervice is aescribed in actail.

This volume conteins a wealth of autientic meterial end should be indispensable to arricultural colleges and experimental stations. For intellisent farmers it contains graphe, charts ard dravings, and gives specific measurements and instructions for construction and use of certain techniques. For aIl adults it gives a concise picture of wat the erosion problem is, and ays in which it can be reduced and controlled.

Soil Conservation, United etates Departwent of sericulture, Boil Conservation Service, as ineton.

rris magazine is issued nonthly. It supplies vorkers and cooperators of the Department of hericultwie eneaged in soil conservetion activities informition oi especial help to them in the performance of their duties. It contains much of interest to farmers and conservation broups outside the Department. Phe artioles are interestingly witten and are usually non-technical.

The nagaine is issued free to workers within the Depertment; subscription price is 1.00 a year, or $10 \not$ a copy. Boil Conservation and National Deiense, Bernett, I. H. United States Depertment of Arriculture, soil Conservation service, ashineton. 1940. 20 p. mireo.

This adaress given before the Forest Freserve sssocia- 
tion of llew York stresses the importance of the derense of the productive soil against the forces of exploitation and waste. In times of war many are of the opinion that conservation is a desirable but not perticularly pressing kind of ork. Var is aged on meny fronts--akricultural included. We have an abundance of land but not enough high-quality, erosion-resistant land to waste any of it. Erosion is carryine off three billion tons of soil each year. The products of erosion (bottom lands covered with sand, stream channels and harbors clozged, reservoirs filled, highway and rail maintenance, flood destruction) are costine a tremendous sum. Somehow these things must be brought in a purposeful vay to all Americans. The soil conservation Service has been lending direct aid to farmers and ranchers since 19:3. Frojects near Temple, Texas are described. There is great need for prograssive education in the field of soll conservation and ise land use. Through the schools, forums, literature, rabio, newspapers, and magazines, this great problem can be brought before the public.

The correlation between soil conservation and national security is generally overlooked. It is fully as important as military and industrial matters. Statistics in this address bring out the immensity and importance of conservation.

This could be used by high school or college stuaents for the problem is clesrly stated.

Soil Conservation Districts in Kentucky, Stete Soil Conservation Committee, Frankfort. Bulletin No. 1. March 1948. 45 p. illus. 
Conservetive estimates indicate that nomally Kentuciry's aniual loss in plant foods removed by erosion is at least $34,000,000.00$. Tis is in addition to the loss oi the topsoil itself. Wany of the soil conservation problens of this state are of a nature which require cooperative action. By Decenber 1942, eighteen soil Conservation districts, containing over $3,000,000$ acres of land, had been or anized in Kentucky. The progress in each district is reported--acreage terraceà, arained improved pesturage land, contour cuitivation established, and trees planted on land not suited for other use. The operation of the districts is aescribed. The fundanental practices wich districts re assisting famers to apply on their ferms include (1) selecting land that is adapted to the use to which it is to be put; (2) supplying the soil amendments that yielo crop increases; (c) establishing and improving: neadows and pastures; (4) controlling erosion and leaching losses; (5) improving drainage facilities; (6) manecing farm moodland; (7) developing farm reservoirs; (8) protecting and encourasing the ovelopement of wildife resources.

This bulletin describes the propram and accomplishments of the soil Conservation service in Kentucky. Farmers not organized should be interested in this report.

Soil Conservation For the reek-end Driver, Consumer's Guide, To1. 7. No. 14. April 15, 1941. pp. 11-14.

This article gives, briefly, conservation practices we can recognize as we pass through almost any countryside lstrip cropping, terreces, forest litter, contour plentine, damsl. on a fourth rabe lovel, this might be read and practiced 
by any farily out for a Sunday riae. If chilaren and their parents are anare of the situation they ofn readily recosnize soil wastage round about them.

Soil Conservation in the Junior Migh school, Strong, Helen Secondary Education, Vol. 10. To. 1. Februery 1941. pp. 29 $-50$

veryone knows that food comes from the soil, but few if any city people consider the ferrs and ranches that contribute to its production. City dwellers heve slight avareness of the immediate or remote common interest in top-soil. aven the farmer ho is losing many tons of top-soil each year from his land may not realize his loss. The fact that declining fertility was due not to something gone from the soil but to lack of top-soil itself was not recognized until recent years. Farm boys en girls can be taught in terms of their onn comrunity. For the city boys and girls the aproach likewise is in terms of something they know and in which they are interested. This kind of teaching calls for community study by the teacher first, and then by the pupil and teacher. This is an excellent article for any teacher to read. It gives an insint to the problem--both in rural and urban comunities.

Soil, Its Use and Conservation, Graves, Geo. ". Science Tuise for Ilementary Schools, Vol. 4. No. 2. Septenber 1.37. $54 \mathrm{p}$.

Soll i not merely "airt, "but is a composition of rock particies, air, water, and organic matur called humus. Soils are forned from rock, decomposition of plants and animela, 
weathering, living organisms, and chemical action. Soils are clossified by either origin or texture. "ithout soil, plant life would be impossible.

Van's use of soil has wasted or improperly utilized the natural and interdependent resources of the soil, forests, Erasslands, and water. Kature's balance was upset and the soil exposed to the action of wind, melting snow, rain; and flowing water changes an erosive process which was nornal under a vegetative cover, to one which is abnornal and destructive. The kinds of ater erosion and wind erosion are described. Methods of control may involve whole matersheds embracing thousands of acres, or a portion of a single farm. The methods discussed are (I) check dams, (2) gully planting, (3) terracing, (4) changes in methods of tillage, (5) changes in land use. The agency concerned wi th control is the Soil Conservation Service. California has several demonstration areas. A list of plants for erosion control in Calffornia is ziven.

The unit on soil conservation carried out by a seventh and eighth prade is adaptable to other grades. The possible approaches and content are excellent. The activities are varied and well integrated with science, social studies and Enclish. The bibliography for teachers is adequate, but limited for the pupils.

This bulletin for teachers assembles the material in a form suitable for teachine in the elementary rades. This should be most helpful in the teaching of soils and their relation to erosion and conservation. 
of Agriculture, Land-grant Colleges, TVA; Nashington. Undated. $59 \mathrm{p}$. illus.

This bulletin is a description of what is happening in the Tennessee Valley, and of how arricultural forces in the land-erant colleges and universities of the seven valley states, the United States Department of Agriculture, and the IVA are encouraging conservation of soil and the restoration of its fertility.

In the Tennessee Valley dems are being constructed to collect water auring heavy rainfall periods. By such collections the dams will help prevent floods and by letting it out gradually in dry periods it will aid navigation. Turbines generate electricity wich aids the farmer at scores of tasks. But no matter how hard engineers work at building dams, the big problem of providing natural water storage on private land remins. Of all the farm land in the Tennessee Valley, cereful estimates show more than a million acres have been destroyed for future use. Plowed unplanted Iand suffers nost from erosion; open-tilled corn lands next; alfalfa and grass planted areas suffer least from both soil or water loss. Cover is injeed the secret to land conservation. Replanting open land to forest, planting land to permenent pastures, terracing, winter cover and rotation are effective methods of control.

The usefulness of TVA' a concrete dams is being protected by cover crops in the fields to prevent silting. Good farming is just as essential to the full development of the Tennessee Valley as wilson, Norris, or other big dams. This attractive booklet contains information about the 
Tennessee Valley and how it is being restored. The photographs are excelient. The economic and social aspects of flooded, eroded areas are stressed, and how scientific research and planning may ring a return of wealth and happlness to the people there. For adults, this material is excellent.

Soils and Security, Bennett, H. H. United stated Department of Agriculture, Soll Conservation Service, Tashington. 1941. 25 p. illus.

Soils have been on the move since the beginning of tine, but no faster than the normal rate of soil creation until populetion pressures forced the cultivation of steep slopes or unstable soils.

In North Africa, China, and western Europe every effort was made to hold erosion in check. In recent years prograns for land improvement and conservation ha ve been put in to effect. In the United states a mighty civilization was built in a very short time but at an unprecedented cost in basic natural resources.

A Survey made in 1954 shomed that in the United States $14 \%$ of the land is essentially ruined for further cultivation and another $55 \%$ is already seriously affected. The causes given are (1) seeningly unlimited supply of land, (z) character of our climate and conformation of surface, (3) large amount of land under cultivation. The effects are (I) we face a serious lena shortage, (2) declining standara of living for milions of fermers, (b) forming more costly, (4) flood problem is ageravated, and (5)resarvoirs, navieable streams, irrigation jitches, etc. are being lilied up. 
The Soil Conservation Service has been successful in working with farmers to check or stop erosion. Specific treatment is varied to meet particular conditions.

This is a forcefuly mitten phamplet on the effect of erosion in relation to our economic national security. It culd be used by high school students in the study of the fur reaching results and cost of soil erosion.

Soils and Soll Conservation, (A Manusl of Conservation for Missouri Teachers) No. 2, Wissouri Conservation Commission, Jefierson City. 1940. $1 \mathrm{l}$.

The subject matter of the unit includes excellent material on soil--its composition, kinas, agencies that form and transport soil, soil vater, factors wich damage soil, land use practices responsible pr erosion, results of erosion and ways of controlling erosion. Ways of improving soil are siven. Conservation of soil in relation to ater, forests, wildife and mineral resources are oriefly discussed.

Fupil activities include testirg mineral content, comparison of texture, effects of cultivation on absorption of ater, evaporstion, etc.

The unit probably could be used most successfully in a secondary ruxal school. It would have little meaning and no appeal to a city group unless ample provision was made for much field rork. The bibliography listed is for tegcher use and is primarily one of aricultural material.

Soils, Jinerais, and Nutrition, Worman, Jonathon, reprint rom Ohio Schools, Vol. so. No. 2, state Departmenti of Education, Conservation Labratory, Columbus. February 1942. pp. 58-59 
In virgin soil there are sone score of́minerals. Those that sre found ven in the minutest trace play a vital part in tie nutrition of plants, animals, and human beings. A deficiency of vital minerals has resulted because of overrefining of foodstuffs or the depletion of soil through bad farning practices. All should neke it a auty to help the farmer put sound conservetion prectices into effect. The Onio State Department of Education and the Division of Conservation and Natural fesources have esteblished a course of conservation in the public schools. Teachers of onio have opportunity to take a six weeks summer course in conservation (all phases).

This article, by a physician, tells of the body's need for uninerals, and how these heve been depleted by improper ferming practices.

For parents and toachers, the article touches on one of the Iundanentals necessary to the health of our children ans upils.

Soil, Water, and Man, Deusine, Murl; (Basic social Education Series), Row, Feterson \& Company, New York City. 1941. $47 \mathrm{p}$. illus.

In oramatic story iorm floods and dust storms are described. The abuses of our Iana by fur traders, pioneers, f rmers, and Iumbermen have Ieft miles of cutover land, scarred and bullied. With no natural cover, the lands had no protection against floods. The hydrologic cycle is simply erplained in words and diagrams. Flanning to prevent floods includes the builaing of dams, reservoirs, levees, treeplanting and intellieent agriculture. The large herds of 
cattle and sheep, and plowine of grasslands.explain the story of the aust bowl. To prevent erosion the soil Conservation service is working with famers to encourage contour ferming, terracing, strip-cropping, gully control, and other practices.

This is an elementary presentation of what is happening to our soils as a result or ina and water erosion. It is simply witten, ana the material is very interesting to chilaren. It is closely releted to United States geography end to science work. The pictures are excellent and beautifully colored. This material is usable with a fifth grade.

Tre Land, published by Friends of the Land, washington. ilius. This magezine, published quarterly, is concerned with the conservation of soil, rain, and man. The material is interesting and informative. Frimarily for the farmer, the practical agronomist, or conservetionist interested in soil and water, it has many items of interest for the average reader, also.

Wembership dues to Friends of the Land (receive The Land, The Land Letter, and other services) is 5.00 per year.

The Land Letter, published by Friends of the Land, Vashington, illus.

This magazine is a supplement to "The Land" (a quarterly magazine) and contains timely articles and news-notes of activities in connection with conservation of the soil and water. Frominent conservationists contribute authentic and interesting material. of special interest to farmers, others also vill enjoy it.

The Land Ve Defend, Dennett, H. H. United States Department 
of Agriculture, Soil Conservation Service, ashington. 1840; $14 \mathrm{p}$

This address, given before the N. A.A. at Milwaukee, sives a picture of what is happening and what has happenea to our lend. Few people realize what soll erosion has cost, is costing the netion--840 million dollars a year. The cost, in terms of highway meintenance alone is 180 million dollars annually.

The dust storms of the $1950^{\prime} \mathrm{s}$, the costs of erosion, the results in terms of clogeed strean channels, etc. must somehow be brought before the attention of all Americens. It is high time to introduce into our schools courses which deal with the soil as a resource basic to continuing national welfere--as a resource that must be preserved.

In 1935 the Soil Conservation Service was established to see whet could be done to control erosion. The service works ith the fermer to develop a practical coordinated plan for applying the best known methods of rainfall conservation and erosion control to his different kinds of land. A description of the way the program works in 600 farms near Temple, Texas is given. Nearly every kina of erosion encountered can either be remedied or effectively controlled.

There is need for continued and comprehensive research. This is a challenge to educators; there is a need for progressive education in the field of soil conservation and wise land use.

This is a phemplet which should be read by all in the educetional field. It points out the great need of bringing to the American public, this immense and vital subject. Ed- 
ucation is one vay of approaching the problem.

Thirst on The Iand, Vogt, William; National Association of Audubon Societies, New York City; Circular 21 . Undated. 31 p. illus.

The marshes and swamps of the United States are a source of national wealth of the first magnitude. re have destroyed vater resources, and are continuing to destroy them by arainage projects. These narsh and swamp areas are important in the maintenance of water levels; narsh arainage causes shrinkage in the soil; loss of water increases the expense of agriculture and thus to every purchaser of food; in many drained areas wildife and vegetation is destroyed.

Practicelly all the draining of salt marshes has been for the avowed purpose of mosquito control. Change in vegetation, wiping out plant and animal life result, yet other methods (besides arainase) are feasible. Inlend, many acres heve been argined for malaria control. That sone drainage is not only justifisble, but necessary, is conceded. However, much euch work is needless and jestructive, and does not accomplish the gol anticipeted.

The remedy for such destruction lies in (1) careful evalustion of all swamp and marsh areas (all aspects of their relationship to man, incluing fur, ish, oyster beas and Hater supply); (2) methods modified to reduce destruction; (3) program of basic research for mosguito control; (4) trained ecologist to recommend urojected areinace operations; (5) active educetional pro ram in connection ith projects.

This phamplet aescribes the traste of one of our resources and how this waste nay be curtailed. It should pocus public 
attention on drainage policies and should prove a factor in developing public opinion against continuance of such policies.

To Hold This Soil, Lord, Russell, United States Department of Aericulture, Fub. No. S21. Washington. August 1958. 122 p. illus.

This phemplet outlines the problem as a wole, exhibits working combinations of control in different parts of the country, and emphasizes principles. Accelerated erosion can be controlled. The practical and immediate way to do it is to combine the cheapest and most appropriate measures into rearranged managenent plans, farm by farm. The same devices of control are used nearly everywhere but with endess variations. Te must change our ways of la na use.

This phamplet telis the history of land use and the resulting conditions in all aress of the country. The quotations telling whet different sections of our country were once like are most interesting and indicete the great need for some action. The nork being done by the Soil Conservation service and its aenencies arouses hope. The discussion of the causes of erosion (semingly unlimited land, pressure brought about by the great need for more food in world iar 1 , unvilingness to recognize first symptoms, etc.) helps the reader to understand the immensity of the problem.

This would be an excellent source book for use in seconary schools concerned ith the study of conservation problems (why our country faces such a sitution, practices wich brought it about, what is being accomplished, and methocs of attackl. The bibliography listed is lete material 
by outstanding witers.

What is soil rosion, Sharpe, O. F. Stenart; United States Department of Agriculture, Soil Conservation Service, Nashington. (Misc. Lub. Ho. 880 ) 1958. 85 p. illus.

Soil erosion is a special type of the eneral erosion which has sculptured the lands. Then land is cleared of its natural cover of vegetation, whon soils e bared by overerazing or fire, exposure to airect attacks of wina and rain iron wich the soil has been protected for thousands of years, induces erosion of an entirely afferent orcer. This process is designated as "accelerated erosion," "man induced erosion," or "soil erosion."

Erosion by rainfall and running water is negligible where the vegetative cover is intact. Little vegetel litter, overgrazing and fire result in sheet erosion, guliies, etc.

Mass novements of the soil and cround moisture heve direct connection. This should be understood before irrigation or other increase of soil noisture is made. slurp, earthlous, caving, soil creep, slides and mudrlons are fully ciscussea.

Lrosion by ind is important only in ereas where there is insufficient vogetation to bind the soil. Sand dunes, drifting togsoil, etc. are discussed rith ays of combating given.

Ever since cultivation began in this country, soil erosion hes steadily sapped the vitality of the land. Lands must be built up--the soil conserved. To accomplish this we must work hand in hand with neture and use strategy based on knowledge of the netural processes. 
This bulletin discusing both na tural and accelerated erosion clarifies our understanding of the erosion processes and aids in our analysis of the problems of soil erosion control and land use.

iritten on a high school level, this would be an excellent handbook for the study of the kinds of erosion, factors causing erosion and aids in controlling erosion. The photopraphs are very helpful.

Youth and the Soil, United states Department of Agriculture, Soll Conservation Service, Region Seven, Lincoln, Nebraska. June 1940. $65 \mathrm{p}$. illus.

The problem of rural reconstruction in the United States is essentially a problem of econonics and planned land use. All agencies--business, propessions, labor, education--must tace an interest in it. certainly education ill be less affective winout the cooperative assivtance of other agencies. Insofer as the teacher-training institution can urain its teachers more effectively in the rural areas that it serves, it should do so. State Teachors college at Mayvilie, North Dakota has been working on a proram Por its prospective teachers whereby they are better itted to help in rural reconstruction. The program of conservation educetion necesserily began with soil, for that is the source of the major part of the mealth of the area.

The units are worked out for grades one to eight. In each unit the activities are generally field trids or experiments whereby the chilaren actually see or experience the conditions of the community. The subject matter content is well organized. Teferences are not defined as whether for 
teacher or pupll, and if intended for children, they are entirely too difficult.

Also included is a complete plan covering the entire subject of soil conservation. The teacher nay gat a full outline of the whole subject and adapt it to elementary, hieh school, or college level. This plen shoula be most helpful.

The visual aids for teaching are excellent. Filn strips available on loan from the soil Conservation Service, $16 \mathrm{~mm}$. sound and silent movies, photographs, slizes, conservation Charts (free from United States Department of Agriculture) and government pulications are listed. 
FOREST RESOURCES

America's Forests, American Forest Products Industries, Inc., 1319 Eighteenth st., Nashington, D. C. 194144 p. illus.

This booklet gives the history of America from a different viewpoint. It tells how forests have influenced America's colonization and development. Beginning with the coming of Lief Eric about 982 , it desoribes the early settlements of Plymouth and Jamestown and the forest products which were so valuable to England. Sawmills were built and working; the forest was the beginning of American manufacturing enterprise. The North Amerioan colonists were excited and amazed by the wealth of the forests. Native to this country were over 1100 species of trees; England has only 29; France 34 . The forest provided man with shelter, fuel, weapons, tools, food, clothing--and still does.

The first need of the developing country was lumber, and the supply seemed endless. Times have changed. Now we know that we must work to product an ever-replenished tree crop. Permanent forest industries are essential to national welfare. Improved forest practices are belng encouraged among forest owners. The usefulness of the forest crop is ever increasing--(plywoods, veneers, cellulose fibers, paper products, mood plastics, solvents, dyes, etc.l.

Fractically all the booklet is written on a fifth or sixth grade level. It is interestingly told and would 
appeal to a group making a study of trees, wood products or the history of North America. It concerns history with which every child is familiar, but from a different approach. I believe it would be of great interest to almost any group as a supplementary reader.

Arbor Day, United States Department of Agriculture, Washington, Farmer's Bulletin No. 1492. September 1940. 32 p. 1llus.

Arbor Day is purely American in origin, and grew out of conditions peculiar to the Great Plains, a country practically treeless but supporting a flourishing agriculture with a soil and climate well able to nourish tree growth. It was first observed in Nebraska in 1872 by J. Sterling Marton, then a member of the state Bogrd of Agriculture, later U. S. Secretary of Agriculture. Tree planting was no new thing in Nebraska, but the adoption of the Arbor Day plan meant organization of the work and the state became known as the Tree Planter's State. Kansas and Tennessee followed Nebraska's lead and by 1885 the plan had spread through many states as an educational festival. It is now used throughout the U. S. and many foreign countries. The observance of Arbor Day has broadened in scope with increasing interest in the wise use of all our natural resources. Instead of being Ilmited to one day's program, the Day often ushers in a whole week devoted to conservation of all resources. The time of observance varies (a table of time and provisions of state law is given). The celebration of Arbor Day is the assumption of an all yearround responsibility, since subsequent care must be assigned 
to individuals or organizations. It leads to greater appreciation of the beauty and civic values of trees and shrubs.

Certainly, sny group planning to celebrate Arbor Day should recognize something of its background and purpose. This handbook is designed for teacher or laymen to fill that need. No suggestive ceremony or outline for observance is given, but the leader of any group participating in such a plan could use this as a basic material to pian a program. In schools also, it would be helpful or as a content of subject matter in a study of trees.

"As the twig is bent," An Adventure in Conservation Teaching, State Conservation Department, Milwaukee, Hisconsin, November 1940. 24 p. illus.

This bulletin is composed of children's own accounts of their study of trees. The class (grades 1, 2) was studying their cammunity. They were greatly interested in the fire department and talked much of fire prevention. They talked about preventing forest fires, too. The question arose as to why it was important to prevent forest fires. To answer the question the children began to study trees. They learned about rangers, fire towers; they wrote stories, poems, and songs about trees; they carried out experiments; they visited a newspaper and a lumberyard to learn the uses of trees; they visited a nursery, a park and a conservatory to learn how trees grow. This account tells of the children's learning in their own community, and the resulting desirable attitudes toward conservation. It is excellent to show what can be 
done with young pupils. It should be very suggestive for the teacher of lower grades.

Behind the Eagle Stand the Forests, Timber Ingineering Company, 1319 Eighteenth St., lashington, D. C. 1941 28 p. illus.

This is a pictorial presentation of the uses of wood in war time.

1) Army--barracks, laundries, portable bridges, hospitals, recreation centers, hangars, airplanes, packing boxes, etc.

2) Navy--barracks, mess halls, classrooms, furniture, keel timbers, trawlers, mine layers, patrol boats, spar timbers, etc.

3) Defense Housing--prefabricated houses, home for workers, one family and multiple units.

4) All industry--churches, theaters, piers, garages, oil derricks, fire look-outs, powder magazines, factories, etc.

The magazine shows the uses of wood. The pictures are small and the value of the publication is questionable.

Books and other Publications Felating to Forests and Conservation, United States Department of. Agriculture, Forest Service, Washington. Undated. 4 p. mimeo.

This is a list of informational books, bulletins, phamplets, and magazines on forests and the conservation of forests. The publications are of a date later than 1935 and should furnish good source material for teachers, students, and laymen interested in forestry. 
Gareers in Forestry, United States Deportment of Ariculture, sashington. Nisc. Fub. No. 249. January 1938. 15 p. me importance of yroper training now and in the future cor a career in the fiela of forestry canot be overestimated. As the numioer of foresters stadily increases and competition becones more keen, thorough education ill become more and more necessary. College is but a part of the preparation needed. It must be supplenented by irst-nand experience in forest or conservation work. Foresters are now employed by the Federal covernient, by bre states, by muncipalities, by lumber companies, wood-usine industries, by educationsl institutions and organizations conducting research in forestry. Industry, honesty, sounaness of character and a liking for the sort of life inich he mast 1 esd and the $10 \mathrm{alth}$ and constitution to stand it are the nost innortant personal regusites of the successful forester.

In this bulletin are described the various fields open to the forester, the character of the work and the trainine necessary. This coula best be used in connection ith vocetionel guidance in high schools or colleges.

arniforest Pacts, Cornell hural school Leaflet, Hew York Stete College of Agriculture, Cornell University, Ithaca. Vol. Fe, Ho. Z. November 1959. $22 \mathrm{p}$. illus. In 19es, nev Zor had 177,028 sums; of this 4,022,490 acres were in woodunds. hem of the oners knem enough about corestery to obtain the hishst returns from these wojlans. A farm ith e flourishing forest is rore than a one-crop business. New Work ierm voojland, nisely 
managed, may have a definite relationship to the productiveness of other croplands. They may yield direct revenue from cordwood, maple sugar, samlogs, posts, hunting privileges, Christmas trees, and plants for ornamental landscaping. The forest floor, properly managed, encourages litter and humus, prevents soil erosion and water loss, and helps growth of new trees. To survive, trees must compete with other living things --caterpillars, ants, borers, beetles, rusts, and most destructive of all--fire. The multiple uses possible for forests--fur-bearing animals, flesh of animals (rabbits, squirrels, etc.), birds, fish, recreation facilities,--all are discussed.

The activities given in this leaflet are varied and worthile--the facts presented may be used by filth and sixth grade children. The bulletin gives the economic values, as well as social and aesthetic. Inch use is made of the community.

Forest Conservation in the Social studies and sciences, United States Department of Agriculture, Forest Service, Tashington. 1940. $137 \mathrm{p}$.

This is a series of units on forest conservation for use in high schools. Unit 1 - Man Conserving the Torest--deals with the misuse of forest lands, services rendered man by forests, and the changes needed in forest management. Unit 2 - is a historical study of the conservation movement from colonial days through 1937. Unit 3 - The Forest, a Guardian of Land and Water --emphasizes forests as they influence water behavior, 
soil, and wind erosion. Unit 4 - Fire, the Red Enemy of Forests--deals with the destructions caused by fire, how fires start, how controlled, and the work of fire fighters. Unit 5 - is on How Diseases and Insects Destroy the Forest. Discussed are the fungi, rusts and blights, insects as attackers, and their control. Unit 6 - is concerned with Managing Forests for vildife Crops. It deals with wildlife capacity, winter range, predation competition, preserves, refuges, etc.

Hith each unit is a list of possible approaches, activities, discussion questions, tests of evaluation and an excellent bibliography. The activities are varied and purposeful. The social and economic aspects are stressed in all units. For use in either biological or social study courses, they should be very suggestive to high school or college teachers and course of study coramittees.

Forest Trees and Forest Facts of Tennessee, watkins, $R$. Ji., Bailey, J. L., Caldwell, J. C., Department of Conservation, State of Tennessee, Nashville. Bulletin No. 6. 1941. 2-79 pp.

Many things are wrong with the management of Tennessee's forests. They could have been managed so they would have continued to produce supply of timber. Other values of forests are water conservation, wildlife recreation, and preventing waste lands. These have suffered and ways of restoring them are given.

A imple key and description of trees found in Tennessee is given. 
This bulletin gives a very good discussion of the tree, it parts, and how it grows, as well as the conditions necessary for forest growth.

Parts of it could be used by elementary schools (firth and sixth grades) and would be most effective in the teaching of the values of forests.

Forest Trees of Arkansas, Buchholz, J. T. and Nattoon, W. R. College of kgriculture, University of Arkansas, Fayetteville. Extension Circular 180. November 1924. $84 \mathrm{p}$. illus.

The increasing interest in outdoor life, and the widened outlook resulting from the spread of education encourages the rational treatment of our trees and forests. This handbook was prepared in response to a demand for information regarding the common forest trees. Altogether, 82 trees are described, with a brief mention of 33 other varieties or species native to the state.

As a handbook on how to know the common forest trees of Arkansas, this publication is very helpful. To be used for a basis of comparison of trees found in other states, it mould also be helpful.

Forest Trees of Kentucky, Kentucky State Forest Service, Frankfort. Bulletin No. 6. 1931. 76 p. illus.

Five-sixths of Kentucky's original timber stand is gone; the remaining one-sixth is largely in scattered or culled stands, remaining from former lumbering operations. The lumber industry still ranks fourth 
from the top among the soil crops in our state. There is a great aeal of land in the rougher parts of Kentucky that will yield little or nothing in any other crops than forest trees. Yet this land is being allowed to become unproductive through neglect. The forest land of the state is losing its capacity to reproduce valuable timber because of forest fires, and wasteful methods of cutting. Kentucky can come into her own as a forest state only by stopping the annual waste by forest fires, and cutting practices. The bulletin describes seventy species of native trees. It is intended to give a brief and usable guide to the trees of Kentucky so that Kentucky may know something of their state's forest resources.

Forestry, United States Government Printing office, Superintendent of Documents, Tashington. Frice Iist 43-z3rd Edition. May 1939. $20 \mathrm{p}$.

The publications included in this list are those concerned with forestry--tree planting, lumber and timber, ranges, wood preservation. Much of the meterial might be used with fifth or sixth grades and higher levels. The prices are nominal.

Forestry of $4-\mathrm{H}$ Clubs, Mattoon, H. R., and Shinn, E. H., United States Department of Agriculture, Nashington. Misc. Pub. No. 395. January 1941. 50 p. illus. This publication suggests forestry projects which may be carried out by $4-\mathrm{H}$ Clubs or other rural groups, or by urban nature study groups. The projects emphasize getting acquainted with forest trees and learning their value to 
their onners and the community. Some of the rojects deal vith phases of managing farm home woollots, farm forestry with respect to local forest trees and their uses, protecting and improving woodlands, planting trees, farm timber products, measuring and marketing timber, etc. The projects give sources of material and illustrative material, guides to stuày and practical activities to be carried out.

As a guide for a director of $4-\mathrm{H}$ club activities this material is excellent. It could well be used by leaders of boy's camps, nature study groups, and others interested in farm forestry. Tre bibliography would be useful to any group studying trees, their uses and management. The Key to Common Trees would be valuable to those who have had no special training in botany.

Grandeur of the Mighty Tree, Mmergency Conservation Committee, New York City. Pub. No. 62. February 1937. $4 \mathrm{p}$ ilius.

Washington is permitting its few remaining tracts of virgin forests to be destroyed. This irreplacable asset is being wiped off the earth forever, for a few paltry dollars. Greed is at the bottom of our problem of saving our woods. These forests serve not only as wonderful living museums instructing the public about our out-of-doors at its best, but as nature's cathedrals where the overstressed and weary can find calm peace, and beauty.

This leaflet is a plea, to the public, to save the primeval forests of our country, in this case Mt. Olympus 
lational Fark in ashinton. The problen is porefully set forth, end if the leoplet received vide enough circulation, it may heve accomplished its purpose.

ardy shrubs, Helizen, C. ., Michisen state colloge, Aericultural speriment tetion, Jast Iansine. Special Bulletin No. 1.44. Lay 1060. 7. p. illus.

Wardy ornarental shrubs are most dosireble in besutifying surromaings. They possess body as well as bloom and ney create shelter as veil as shede. They are usorul in softening and harmonizine the harsh line effects of the house, beautify corners and boundaries of the lewn, screen objects or scenes wich are not ettractive nor in unity uith the eneral besuty of the erounds. succes in rowine shrube is nessured largely by the hardiness and adaptobility to the conditions of soil and exposure. The clinstic conditions of ichicen are so variable that many ornanental shrubs are surficiently nordy for planting in some sections cna not in others. A map indicetes the herdiness of sarubs, and the eections of the state were sirubs of varying hardiness will pol. Descriptions of the shrubs include foliae, flovers, soil neded, and harainess.

For homeomers interested in plenting of shrubs around ichican homes, this phamplet is an excellent euide. Identification rey to the gruits of the Irees of Ivew Jersey, scovell, I. I. Now Jersey tate col ece of Arrioulture and Aricuitural experinent station, zuteers University, rew runswick. June 1967. $16 \mathrm{p}$. mimeo. 
This key gives a description of the various kinds of flowers and fruits found on trees. The key itself is very simple and easily understood. No scientific terms are used. This makes it usable vith upper elementary pupils and non-trained adults in the identification of trees, not only in New Jersey but in most reglons where deciduous trees are found.

Indiana Forestry Frogram Creates Future Timber, Aids Recraation, Indiana Department of Conservation, Division of Forestry, Indianapolis. Undated. 4 p. illus.

Indiang's state forestry program consists of (1) demonstration the possibilities and value of timber production on otherwise uncultiveted lands; (2) promotins the growing of trees by protection from forest fire and classification of mooded tracts; (3) furnishing seedlings for reforestation. In the state Forests and came Preserves shelter houses and drinking fountains provide facilities for persons who visit them. Artificial lakes provide fishing and recreation. Markers add to the educational use of forests.

This phamplet tells briefly of projects under ay in conservation of forest lands in Indiana, and might be of interest to those concerned with conservation practices.

Indiana State Parks, Indiana Department of Conservtion, Division of State Parks, Lands, and faters, Indianapolis. Unciated. 26 p. 111 us.

Described in this folder are the 16 state parks and 
menorials found in Indiana. Their location, history, recreational facilities, and the nature study interests are given.

For vacation seekers, and nature study groups, this folder describes hat Indiana has to offer. Teachers could use parts in connection with social studies for several places of historical note are given. The folder is on a reading level of fifth or sixth graders.

Kentucky's Forest Conditions Through the Camera, Kentucky State Forest Service, Frankfort. Bulletin $9.195254 \mathrm{p}$. illus.

The pictures tell the story of the use and abuse of Kentucky's forests. They show the harvesting of lumber, forest damage, erosion, and corrective work of the Forest Service. The abuse and neglect can be remedied by education, fireprevention, and tree planting.

This bulletin is issued with the hope that it will aid citizens of the state to better understand forest conditions from an economic as well as aesthetic standpoint.

The pictures are excellent and could be used to advantage by schools in certain teaching.

Iist of Publications of the Conservation Department, New York State, Albany, N. Y. 1937 2 p. mimeo.

This list includes generel information, bulletins on forestry and pest control, recreation facilities of state parks, biological surveys of various water sheds, stream pollution, and reports on water power projects. 
Some of these publications would be useful to teachers, but since no annotations are given, each teacher would have to decide for herself. Much of the material is free or noninal in price.

\section{Little Folks Forest Friends, Tennessee Department of} Conservation, Nashville. Educ. Pub. No. 4. Undated. 12 p. illus.

This colorine book for use in first or second grade contains black and white drawings of forest animals, and ays of putting out fires (water, dirt). Under each picture is a sentence describing the picture.

Children would enjoy coloring the pictures, but would need authentic colored ones to go by. As supplemental work, it is very good.

Living and Forest Lands, United States Department of Agriculture, Washington. Misc. Fub. No. 388. 1940 $48 \mathrm{p}$. Illus.

Because of the many contributions of the forest to the welfare of both individuals and nations, forest conservation is of intense interest. Frimitive man was dominated by the forest. The forest provided him with protection, food and shelter with little effort on his part. The forest kept him from wandering, from contact with others, and hence retarded his progress. When man progressed to the point where the forest no longer dominated him, increasing use of forest resources became necessary for his further progress. Soll, water, temperature, altitude and slope, prevailing winds and 
ocean currents all have their influence on the forest which in turn affects our daily lives. Our uses of mood for food, fuel, clothing, domestic uses, lllumination, communication and transportation, are examples of our great need for forests. Forests determine the locations of many industries because of raw materials and through their influence upon stream flow. The a emand for lumber has decreased, but new uses such as pulp, rayon, cellulose, plastics have increased. Forests create commerce domestically and with foreign nations; they provide gainful employment to an average of 650,000 workers regularly; they play an ever increasingly important role in leisure activities. Forests should be considered as a renewable resource, and should be treated as crops. Reforestation nay be natural, or artificial. Federal and state governments advise and help private owners as well as care for public forests. The benefits received justify this aid. This bulletin is a guide to the social and economic aspects of forests and forestry. The principles of conservation are the bases for the report. The maps, tables, charts, etc., and the activities listed are helpful. The bibliography is good.

For use at junior or senior high level, the bulletin could well be used in a study of conservation, or in reIation to geography or economics.

More Trees and Shrubs for Nebraska, Nebraska Game, Forestation and Parks Commission, Lincoln. Conservation Eulletin No. 1. Undated. 4 p. 11lus.

Nebraska was well blessed with shrubs which furnished 
edible fruit for the food of wildife in the early days. As a result of burning fence rows, putting more land under cultivation, and increased grazing of livestock the amount of wild fruits has been reduced to a marked degree. Such shrubs as Buffalo Berry, June Berry, Choke Berry, and others, should be increased and may be ade to serve a three-fold purpose, that of furnishing a protective cover and food for wildlife, supplying food for the family, and helping to control soil erosion. Methods of propagating from seed are given.

Nebraska became known as the "Tree Planters" State" because many of its early settlers established many windbreaks, shelter belts, and woodlot plantings for their protection and for the benefit of future generations. While trees are being planted in Nebraska mainly for wind protection, they also act as barriers against soil erosion and evaporation of moisture. The best suited trees for Nebraska are listed, along with directions for planting a tree.

Written on a level which may be used by fifth or sixth grade, this article could be used to advantage, especially in Nebraska schools, in a study of erosion, conservation of water, or wildife. Farmers, too, should benefit from it.

New Forest Frontiers, United States Department of Agriculture, Forest Service, Washington. Kisc. Fub. No. 414. April 1941. 76 p. illus.

The great American paradox--serious want in the land of plenty--agriculture problems, unemployment, low standards 
of living. These problems seem more acute because there are no new lands to move to. Fortunately some of our natural resources are renewable and can be nanaged for perpetual production. Forests are one of the most important renewable resources. They can be used for several major purposes at the same time so that their value and services are multiplied. Manufacture of useful products from forest materials provides employment for millions. The effort to rebuild, to capitalize on forest conservation as one means to rural and national rehabilitation must be directed on both privete and public lands. Some problems facing this management are (1) wide variation in objectives between classes of ownership, (2) inadequate technical knowledge, (5) hazards of fire, insects, disease, (4) underdevelopment of new uses and markets for wood, (5) need for replanting idle acres, and numerous others. The American people are heavily dependent on forests for myriad products and services, for employment, and income, and for national defense. There is thus a public interest and responsibility for all land forestry regardless of ownership.

This bulletin presents the outlook of American forest problems--their social and economic aspects, and a possible solution through research and public cooperation. The pictures, maps, and graphs tell the story vividly. These could be used with fitth or sixth grade classes. The social and economic phases are such that junior high sbhool students will profit. To be 
used in civics, economics, or any other phase of modern problems, this material is mell mitten.

Our Forests, United States Department of Agriculture, Forest Service, Washington. Misc. Pub. 162. July 1940. 38 p. illus.

A forest is considered as a community of plants and animals living in close association and in varying degrees of interdependence. The law of forests is the survival of the fittest. Given is a discussion of how a tree lives and grows. The forest recions of the United States are the northern, hardwood, southern, Rocky Mountains, and Pacific Coast. The kinds of trees growing in each region are discussed. The uses of forests are many--wood, paper, rayon, cellophane, plastics, rosin and turpentine, food, protection of water sheds and regulation of water supply, protection from winds, pleasure and recreation. Enemies of forests are fire, insects, diseases, grazing animals that trample roots and young growth.

In 1905 the Forest Service was established to manage forests and carry on research. The work of forest supervisors and rangers is described. Forty-three states have established forestry departments patterned after that of the Federal Government.

The amount of deforested land in the United States has been increasing yearly. It is hoped that wasteful exploitation is near an end, but one of the greatest present-day problems is fire. Extensive systems of fire suppression and control have been developed. The Federal 
and state governments cooperating under the clark-lfoNary Act are yearly reforesting portions of denuded forest lands.

on a junior and senior high school level, this publication is excellent supplemental material to give the values of forests, and the steps being taken to restore and conserve them.

Proceedings of the Second Fark Naturalist's Conference, United States National Park Service, wash1ngton. November 1940. 507 p. mimeo.

Papers were presented at the Conference on the work of naturalists in National Parks. These papers and following discussions were centered on the interpretative functions of the naturalist--how to instill in the visitor a love of nature by actual contact with its manifestations, emphasizing its beauty and orderliness, its inspirational and educational values and thus engendering an appreclation of and interest in its conservation. The naturalist has the responsibility to guide, to reveal and to explain. The work of the Park naturalists includes that of junior nature programs such as field trips, informal discussions, museum study, observation, etc., carried on at sequoia and Rocky Mountain National Parks. For adults, programs include guided camera trips at crater lake, game stalks at Yellowstone, water cruises at Acadia, winter sports (sking) at $\pi t$. Ranier, museuns, exhibits, lectures, and guided trips at other Parks. Numerous other papers deal with research, libraries, collecting, publications and cooperation within the National Park Service. 
The proceedings are interesting and a great variety of material is presented and discussed. The interpretative function and techniques for carrying out this work is the theme of the publication. The educational impIlcations are stressed. It is of interest to educators and people concerned with the services provided by our National Parks. If individual papers were issued for publication the general public would benefit from some of them.

Products of American Forests, Hall, J. A. and Mosley, T. J., United States Department of Agriculture, Forest Products Labratory, Washington. August 1939. 48 p. illus. The forest is a storehouse of wealth in the form of wood and other tree products of great variety. Forests have great usefulness in keeping the land productive and habitable. They absorb rainfall and check excessive runoff; they mitigrate destructive and drying winds; they provide habitat for birds, game and fur-bearing animals; they add beauty and interest to the home-owner and recreation seeker. Under the proper system of harvesting, the forest can render these essential services while yielding its regular contribution of products. These products are (I) wood for construction, plywood, veneer, furniture, railyay ties, etc.; and as fuel; (2) wood products--pulp for paper, rayon, plastics, etc.; (3) turpentine and rosin; (4) maple sugar; (5) tannins; (6) dyestuffs; (7) nuts (pecans, walnuts, chestnuts, etc.); (8) pharmaceuticals (herbs); (9) volatile olls (oil of cedar leaf used in insecticides and linirnents; oil of 
hemlock and spruce needles used as perfume in greases, and in liniments); (10) fruits (haws, cherries, plums, etc.); (11) miscellaneous uses (pine needles as padaing in upholstry; willow, hickory, basswood for chair bottoms and handicraft work; tallow from boyberry, etc.).

This is a very complete account of the services rendered man by forests and their products. The processes by which wood is converted into plywood, rayon, plastics, paper, etc. are described in detail. A knowledge of wood composition and chemistry would be necessary for understanding these. The bulletin could best be used by high school students to learn the wide variety of forest products.

Proposed John Wuir--Kings Canyon National Perk, Emergency Conservation Committee, New York City. January 1839. Fub. No. 74. 20 p. ilius.

The proposed bill to come before congress renews the long effort to make Kings River Canyon a national park, and proposes to bring Redwood Mountain and Redwood Canyon into the National Park System. Redwood Mountain is rated as the largest stand of giant sequoias in existence. The owners do not want the trees cut, but the area is menaced by sale for defaulted taxes. Kings Canyon already belongs to the people, and can be included in a national park without purchase. The problem is to keep it a wilderness. Big electric utilities believed they could develop an abundance of cheap electricity on Kings River, and opposed a national park. Experience taught power companies that rivers with a low summer flow were expensive, so their 
entries were dropped. A few farmers graze cattle in the meadows, so are opposed to a national park. Sportsmen object to turning this high country into a game sanctuary. Summer home owners object to the project. The regional office of the Forest service opposes this project too. It is interesting to note the forces at work in the promulgation of conservation projects. This article gives a general view of the problem of this proposed national park, and the various factors involving such procedure. This article would be of interest to conservationists, and the public in general.

Redwoods--Ever-Iivine Memorials, Grant, J. D. Save-the Redwoods Ieague, University of California, Berkley. 1929. 7 p. illus. After World $\operatorname{lar} 1$, the idea of appropriateness of trees as memorials to soldiers who had given their lives became popular in all countries which had engaged in the war. One such memorial was dedicated in 1921 to the memory of Cal.R. C. Bolling. It is a block of Redwood forest on the Eel River in California. Other memorials have been acquired under a plen inaugurated by the savethe-Redwood League. It is the plan of this League to develop the nemorial grove iaea as a means, not only of sentiment and respect, but of preserving an increasing number of beauty spots among the Northern Redwoods.

Trees as nemorials have much to recommend them, and surely there are fev men who would not be happy in thinking that their memory was to be kept green by a tree. The double purposes of preserving our foreste, particularly 
the Redwood which must soon disappear at the hands of lurbermen, and of sentiment are carried out in such a plan.

The publication is of interest to show what groups are doing to preserve our forests.

Redwoods of the Fast, Chaney, Ralph, it. Save-the-Redwoods League, University of Calirornia, Berkeley. Undated. 7 p. illus.

Possil evidences show that the reawood, now confined to a restricted area on the California-oregon const, mas once prevalent in the Northern Hemisphere. Due to changing conditions of the earth--the building of nountain ranges, the rise of the continents to a hicher level above the sea, and alteretions in its climete the causes of which are incoripletely understood--the range of the redwood has gradually been limited until the coast series is found only in California ana Southern Oregon, while the Sierra species is confined to scattered groves in the Sierra Nevada.

This bulletin would be of interest to junior and senior high students in an understanding of the changes which have taken place on the earth, and the resulting influences on the life of this earth.

Reforesting, Fettis, C. R., New York Department of Conservation, Albany. Bulletin 2. 1956. 30 p. illus.

Iree planting pays. It pays the farmer, the landomer, the community, the sportsman, the municipality, the state and the nation. These benefits are in various 
ways--lumber products, recreation areas, cover for gane, protects $l$ ands from erosion and flood. We are so accustomed to rely on nature to provide timber and forest products, it is hard to realize that trees must be planted. The Conservation Department has developed tree nurseries to supply small trees at a nominal cost. Directions for selection of trees based upon soll factors and uses to be made of the trees are given. The uses of pine, spruce, balsam, and cedar ana conditions necessary for successful growth are given. Likenise, planting, care, yield, etc. is given.

This bulletin should be of use to any farmer, landowner, or other persons who are contemplating planting of seedlings.

Sanctuary and Nature Trail Survey, The Garden Club of America, Conservation Committee, New York City. 1959. $31 \mathrm{p}$.

This survey was started with two objectives in view: to find out how many actual Sanctuaries and Nature Trails there were in the states where the Garoen Club of America exists and how much of the work of establishing them had been done by Club members; and to learn whether Club members were conscious of potential sanctuary areas in their neighborhoods.

The Survey found sanctuaries and nature trails where the Club had contributed funds in 28 states, of which 12 were established by Garden Clubs, 6 owned by Garden Clubs, 9 wholly supported by Garden Clubs, 8 partially supported by Garden Clubs. A total of $1: 7$ Sanctuaries and Nature 
Trails were visited, 5 of wich nove projects of the carden clubs. For eaci anctuary or Nature Trail s brief description of size, operation, mainterance, and conservation proeress is iven.

Tis survey stresses the importance of proper protective measures for canctuaries.

Fotential barctueries were found to be numerous, ana these reports vere filed for future use.

This Surver would be of primery interest to rarien Club mbers, but it is heartening to know the civic organizations are arare of the needs of such conservation practices, and are participating wherever and werever possible.

Seving the Redmoods, Save-the-gedwoods Ieaeue, University of California, Eerkeley

Tie Save-tho-kedvoods League issues froin tine to t tre a bulietin of 7 to le pases, illustrated, in which ere told the accomplishents to aete, and the future plens of the League. Some of the pajor accomplishrents over a period of 10 bears have been (I) raisire fungs to contribute toward the purchese of kedrood areas (in cooperation with state fundsi, (2) conauctins surveys, (5) estabiishrient of amorial groves, (4) helpine in removal of fi re hazaras, (5) advisine fith stete Comission of larks in resard to builaing ighays through feanood Forests.

Such pubications eive ideas as to the vays in which interested roups can eid ard suppenent evernment projects for preserving sorie of our natural resurces. 
Suggestions for Integrating Forestry in the Modern

Curriculum, United States Department of Agriculture, Forest Service, Hashington. 1940. $3 \mathrm{p}$.

This outline suggests the ays in which forestry may be integrated in the curriculum. On the elementary level, emphasis is placed on the home, school, and comunity as it is influenced by forests and trees. on junior high school level the emphasis is on adaptation of the individual to his environment and stresses forest improvement. At the senior high level emphasis is on understanding and improving group reletionships and trends in modern society. Stressed is the influence of forests on living conditions, employment, control of ownership, problems of reforesting, conserving and utilization of forest resources.

For teachers wishing to teach forestry conservation with units and courses commonly taught, this outline gives many ideas on subject matter. No suggestions as to approach, or activities are given, but as content material it should be helpful.

Taming Our Forests, Suere, Martha 3 . United States Department of Agriculture, Washington. August 1939. 87: p. 111us.

Although one third of our land is forest land we are not getting as much wood from it as we are using. Te are importing wood from other countries. Trees cannot serve us if most of their effort is spent in a struggle with each other for light, water, and soil. Wild forests cover nearly 10,000,000 acres and give us pleasure and information. But 
we cannot aepend on them to give us what we need in lumber. only from the forests which we can tane can ve expect a continuous supply that will help us to build a secure and increasing prosperity. It takes a trained forester to break in a wild forest to the service of man. He must realize that forests are for the service of human beines; he nust know that trees vill supply special demands; he must know about soil, water, seedlings, and numerous other aspects. Some wild forests and cut-over lands can be reforested. cther lands must be replanted. The rork done by the Torest service is described. Varvesting, too, is an important part of the work. Inemies to be combatted are fire, disease, and insects. Detailed descriptions of protecting forests are given.

This bulletin telis how man henales the porest to keep it productive. In order to meet the needs of the nation, our forests need to be managed by trained experts. This bulletin (on junior or senior high level) would be most useful for a general stuag of forestry or in relation to geography, science or vocational guidence.

The Conservation of prees and Eorests (Conservation ieek in the Schools of New Jersey. 1938) New Jersey State Conservation Cormittee, Prenton. $15 \mathrm{p}$. illus. About $43 \%$ of the total area of Nev Jersey is forest land. In North Jersey, the trees are mostly deciduous. South Jersey's woods are mostly coniferous. The perts of trees and interestine life story is told. Uses of trees as source of lumber, to prevent erosion, to insure regularity of stream flo, as home for vildife, and as 
recreational and aesthetic values, are aiscussed. Enemies of trees are insects, fungi, and fire. Ifforts to reforest New Jersey made on the part of the Department of Conservation, the work of the CCC, state nurseries and other aspects of reforestation are taken up.

moch use is made of rield stuay in knowing and appreciating trees. The naterial is general in scope, but each teacher may select the portion best suited to her needs. The bibliography is excellent.

The Iiving ilderness, published by the ilderness Bociety, fashinton, D. C. 15 p. illus.

The Living rilderness is a publication devoted to wilalife end wilderness areas--their preservation and timely convents on the subject. The wilderness is considered a valueble netural resource, and should be protected from the influences of civilization, as highays and other developments which clash with the primeval environment. The articles are interesting and non-technical: for adult readers.

The rational Fark System, United states Departient of Interior, Vational Park service, washington. January 1938. 12

.ith motor travel constantly increasing, the National lark service hes expanded to neet the desires and needs of the thousands of visitors each year. Conservation in the parks was aided by the ccc. Laugtion of the visitors is an interestine and important phase of park developnent. Trailsie museums, information by raneers and perk-naturalists 
and other educational facilities have been developed. Recreational and living accomodations have al so been developed.

Fach of the national forests, battleffeld sites, cemeteries, memorials, etc. are described as to what to see and do in these public-owned and administered areas.

As a source of information for tourists, for chilaren in their school work, and general knowledge, this publication is interesting and accurate. The Olympic Forests for a National Park, Brant, Irving Emergency Conservation Committee, New York City. Pub. No. 68. January 1938. 20. p. 11lus.

On the olympic Peninsula of the state of ashington, the people of the United States own the largest great forest wilderness still standing in their country. These forests and, in summer, the mountain meadows and tundras, are the nome of the Roosevelt Elk. Threetimes attempts have been made to set aside the area for everlasting preservation. So far these have falled. Lumber interests and the United States Forest Service have led the opposition. The President favors an adequate park and that parts might be selectively "logged." This logging is opposed because it would involve a change in netional park policy which is of vital importance; furthermore the forests are so dense and the mature trees so enormous, the felling of one tree damages dozens of others. The opposition of the Porest service is based on hostility toward the Park service, and a gradual developinent of a comercial attitude towerd the national forests.

This publication is issued to inform the public of 
the situation, and urge them to express themselves on the subject to the President and the secretary of the Interior.

It is interesting to note the varying interests at work for and against conservation programs.

The Story Told by a Fallen Redwood, Fritz, Fmanuel Save-the-Redwoojs League, University of California, Berkeley. Undated. 7 p. illus.

on Merch 13, 1933, this giant redwood fell, in Humbolt Redwoods State Fark, Calif. Its 1200 years is a story unique in the annals of science. Facts about this fallen tree--average diameter $12.1 \mathrm{ft}$; height $310-320$ ft.; age at stump section 1204 years; gross volume 95,000 board feet; probable weight 500 tons.

Historical facts- 728 A.D. the stump started; 1066 Norman Conquest; 1215 Migna Charta; 1492 Discovery of America; 1778 Declaration of Independence; 1861 Cival Tar; 1914 World War 1; 1932 the outer and last gtowth ring formed.

The life story told by the cross section shows rapld growth, slow growth, many fire scars. The root system indicated many floods and subsequent building up or raising of ground level.

This very interesting leaflet serves to interpret the signlitance of the Redwoods and to increase ap reciation of these remarkable trees. It might well be used with upper grade elementary pubils to stimulate interest and appreciation. The diagrams are clearly 
understood.

The Tasks Ahead of the Save-the-Redroods League, Merriam, J. C. Save-the-Redwoods League, University of California, Berkeley. 1984. 7 p. illus.

The League, organized to preserve the oldest trees in the world, is concerned with five major items--(1) complete scientilic study of the redwood, (2) need for intensive examination of the eoonomic side of the redwood program, (3) recreational values of reawood recions, (4) educational program covering scientific value, economic application and appreciation of aesthetic values, (5) aesthetic and inspirational values.

The League has been instrumental in preserving as State Farks, over 80,000 acres of the native redwood fringe of forest along the Pacific Coast. It has supported all efforts of the National Forest Service to secure areas as would make possible continuing scientific and economic study of all phases of the redwood forest.

This League is one of the groups interested in conservation of our natural resources, particularly the redwood trees. The program it has set up, its objectives, and accomplishments give an idea as to what needs to be done, and what can be done. Of interest to similar groups, the bulletin might be helpful.

The Woody Plants of Kentucky, Garman, H. Kentucky Agricultural Experinent Station of the State University, Lexington. Bulletin No. 169. January 1913. 62 p. illus. The woody plants of Kentucky are a very miscellaneous 
assemblage of species which appear to have been brought together by a diversity of influences. Probably the mountains in the eastern part of the state furnished most of them having constituted a sort of reservoir which overflowed as the land to the westward became habitable. The intermediate position of the state results in the presence of a surprising variety of species. Side by side in the mountains one finds northern white pine and southern magnolias. Added to these is a host of individuals respresenting most of the trees and shrubs of the eastern United States. Conditions inIluencing the alstribution and assembling of our trees were moisture, temperature, and means of dispersal rather than soil influences. However, the chestnut is the one tree that shows in a marked way the influence of soil on its distribution. A description and distribution by counties for the various plant families is given.

This bulletin is a result of years of collecting and observation, and is nearly complete. It might be useful in a study of Kentucky Forests on a high school level.

The work of the United States Forest Service, United States Department of Agriculture, 溻ashington. Misc. Pub. No. 290. January 1938. 40 p. 111us.

During the 15 years beginning with 1890, the trend toward public forestry moved swiftly, culminating in 1905 with the creation of the United States Forest Service in the Department of Agriculture. Forestry, as applied by the Forest Service is concerned with the perpetuation and development of forests that they may continue their many 
beneits to mankina. The National Forests are for the most part located in the mountainous regions of the country. Preservation of tree growth is of ereat importance in preventin or retardine soil erosion and in conserving the ater for use of mankina. The policy under wich the national iorests are acministered by the porest service is wise use. Before any progran of timber ales in any national forest, forest officers nake a c reful survey and prepare a plen of menasement. Lange administration involves the protection, development and mangement of the forage resource. illaIice is considered by the Forest gervice as a resource to be managed for permanent protection and use. Terious improvements in the forests include fire lookout stations, reneer stations, telephone lines, roads, trails, briages and other work. The Eorest vervice haintains nurseries Lor reforesting vast areas aevastated by ire on heavy 10Geing. Iire is an ever-present anger in the national forests. The Porest cervice lays trenendous stress upon forest fire prevention. In its control mork against tree

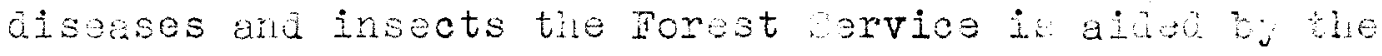
Division of Forest Fathology and other egencies. of basic importance is forest and range research carried on by regional forest and range experiment stations. The Forest Service also cooperates ith jtate and privete Porest-Iana owners towara better management of merican forests as a whole. The Forest service pleces at the service of the public its fund of information ebout iorestry, photographs, slides, neps, filmatrips and novies. The many aspects of the Forest Service are presented 
in this bulletin. on a junior hish school level, it might be used in a study of forestry or in vocational guidance.

Useful Trees of the United States, Department of Agriculture, Forest Service, Washington. Unaated. 52 p. ilius. This series of leaflets describes the history, habitat, wood, foliage, flowers, seeds and commercial value of important trees of Americen forests. A distribution map for each species is given. The species covered are Alpine fir, Baldcypress, Eastern hemlock, Longleaf pine, Northern white pine, Red gum, Sugar maple, Sugar pine, western wite pine, White oak, and yellow poplar.

This series could be used on a sizth grade or junior high school level in a study of forests, uses of wood, or in connection with geography.

What Forests Give, Bruere, Martha B. United States Department of Agriculture, Forest Service, Washington. Januery 1940. 79 p. illus.

A forest is a community of plants and animels, of wich trees are the most important members. In the days of the pioneer the forest furnished wood for heating and cooking and builaing; squirrels, turkeys, deer, maple syrup for food; and fox or molf for skins.. Toalay, although we have only $630,000,000$ acres of porest lands left, we want from forests things of which our greatgrandfathers never areamed. Ve use forest products for Dlynood, pulp, tanning leather; we get sugar from the maple; use rosin and turpentine and other uses. Forests 
hold the soil in place, and help hold back the wind thus influencing erosion. Forests can help prevent floods by absorbing rains, melting ice and snow. Trees act as windbreaks and soil holders, especially in the Prairie-Plains area. Forests are labratories for experiment stations, museums, and out-of-door classrooms for scientific study. Besides goods, services, and knowledges, our forests Eive us great recreational facilities. What more forests can give us in the future depends on ourselves--the care and use we make of them.

This publication is intended to show us the great source of wealth we have in this natural resource--our forests--and it does just that. Interestingly and simply witten, it describes the methous of making plywood, "pulping," and of "stilling" oleoresin into naval stores. Farts could be read by sixth graders, ana all could be read by junior high school students. It would be of value to groups studying conservation of trees, or in relation to geography and science.

That is a Nature Sanctuary? Agersborg, H. $\mathrm{H}$. K. American Forests. August 1927. pp $98-400 ; 415$. illus.

A Nature sanctuary is a place set aside and allowed to remain unspoiled by man. All the people may indirectly benefit from a Nature Sanctuary.

Only in a Nature Sanctuary will it be possible to perpetuate the native flora of the region indefinitely. Such an area is a self sustaining entity of unusually hich economic value. In our Nationgl Forests, where grazing is allowed, it is of eminent importance. Low- 
ever, where grazing by domestic cattle is allowed, actual or real Nature Sanctuaries are impractical if not impossible; in most states of the Union, only quasi-Nature Sanctuaries are possible. As a permanent habitetion for indigenous resident fauna, the Nature Sanctuary must be large enough to support a certain number of animals throughout the entire year. Unfenced, large sanctuaries, with a friendly buffer terrain, may be selfmanaged provided the proper food chains exist between herbivore and carnivore. In a natural state a Nature Sanctuary has a surplus of food and cover plants. To maintain it as such, the control must be either natural or artificial, or both. Artifically controlled, it is no longer a real Nature. Sanctuary.

Most of us are under the inpression that the National Farks and Forests are real Nature Sanctuaries. Such is not the case, and this article explains why they are not.

For the adult reader, this is interesting and informative material. 
An Outline of the vater Tacilities Frogram, Unitea states Department of Agriculture, Boil Conservation Service, Tashington. 1940. 22 p. illus.

Briefly given is the Govermment's program for building, supervising, demonstrating and direct lending for water facilities. The program provides facilities for storage or utilization of water for farm gardens, crops, hay lands, ranges, pastures, stock and other agricultural purposes in the form of ponds, reservoirs, wells, dains, pumps, springs, etc. It applies (in arid and semiarid areas of Western States) to farmers and ranchers who agree to (1) furnish acceptable amounts of labor and material, and (2) practice sound management which will provide soil and water conservation. Installation may be handled by the Department of Agriculture or fermers with the assistance of the Department. Top expenditure for any single project is $50,000.00$; the average is about $72,000.00$. Repayment of the loan is at three percent interest; no loan for more than twenty years. Tenants may use one of three plans outlined.

This phamplet would be of interest to farmers within the area to benefit--namely Arizona, California, Colorado, Idaho, Kansas, Hontana, Nebraska, New Mexico, North Dakota, Oklahoma, Oregon, South Dakota, Iexas, Jtah, washington and vyoming.

Conservation of rater, (Conservation theek in Schools of New Jersey, 1936); New Jersey state Conservation Committee, Trenton. $15 \mathrm{p}$. illus. 
The theme for observance in the schools during Conservation Heek, 1936, was water. The importance of water as airect composition of all living thines, and dependence of all living things upon water is stressed. Froblems in conservation of water in New Jersey are related to its dense population. Hater supplies to cities and towns, problems of sanitation, pollution, and health are discussed. "illdife and water--food supply, drainage, etc. are dealt with. The influence of water on erosion and control measures such as cover crops, contour plowing, crop rotation, and so on are described. The work of the forest in relation to retarding erosion, run-off, and floods is included in this study.

This material, for teacher use, is designed to cover one week's work. However, there would be only a bare beginning in such a time span, and I think it could be carried on for several weeks. Maps, excursions, experiments, etc. are included in the activities. The work is very general, yet each teacher could localize it to her own needs. The bibliography is helpful.

Tollution--Too Bad to be True, Englis, Blye; American Forests. September 1937. pp. 442-443;452; 463 illus.

Fublic Enemy No. $I$ is not an individual but a network of polluted rivers that menaces the nation. Because of its effect on our health, our recreation and our inances, no other national hazard is more intimately interwoven with daily living. Industrial plants and cities dump tons of raw sewage into rivers; oil from ships ruins beaches. Vildife (fishes, shell fish, water plants, etc.) is lestroyed and the health of our people is ereatly endangered. The remedy is 
proper sewage treatment and treatment plants installed by cities and by industries. The Federal Governnent alone should be responsible, for when one state in a river basin refuses to cooperate it nullifies the entire watershed program. This article is concerned with the effects of pollution on human health and recreation. The influence of monied interests defeats the program of sanitation; the public should be aroused and should act.

This article expresses very clearly some of the effects of pollution. Surely every interested citizen shoula read and heed it.

Regional Flanning lart 5--Red River of the North, National Resources Plgnning Committee, Washington. August 1937. 80 p. illus.

The Red River of the North drains the states of Minn., N. Dak., anj. S. Dak. The problem of this area is ater-floods, droughts, subsurface level, and pollution. The three states, with Federal assistance, have had surveys made and have a substantial start in actual construction. An interstate compact creating an agency to administer the plans has been established. The major water problem is the conservation of run-off in lakes and reservoirs and its release to stream channels at a rate which will provide a dependable supply at the time needed. The physical characteristics and climatology are described. Trends in precipitation are definitely downward. Rural population has reached at least a temporary maximum. The area is industralized to a limited extent. There are fine wildife and recreational opportunities. The area has no irrigation; 
rainfall is light in the northern and western portion; conservation of precipitation is important. Urban requirements are of minor importance. Hydroelectric power development does not enter as an item of major importance. The principal water requirements for the basin are: (1) storage in natural lakes and reservoirs; regulated release of sumface water to produce stream flow necessary for water supply and dilution of waste; (2) development of certain low-water stream channels; (3) correction of flood-flow conditions; (4) restoration and stabilization of water areas for recreation and wildife; (5) rehabilitation of drainage works of certain fertile lands, and lands uneconomically drained; (6) construction of small dams on normally dry streams; (7) study of warrantability of additional hydroelectric power production. Various storage projects, channel improvements, sewage treatment, etc. are listed and described. This study is a plan of attack on interstate problems with Federal assistance. The water problem is one of importance to this area, and involves much plannins. The material is for Congressional information, but contains much for students interested in geology, agriculture, and engineering projects.

egional Planning--Part 6--The Upper Rio Grande Basin, National Resources Cormittee, Tashington. February 1938. 566 p. illus.

This investigation is concerned with the water problems of the Rio Grande arainage area which lies above Fort uitman, Texas. Valley lands of the Upper Basin are devoted to agriculture almost entirely. Because of scant 
precipitation irrigation is required. The prime purpose of the joint investigation was to determine the basic facts needed in arriving at an accord among the states of Colorado, Niew Mexico and Texas on an equitable allocation and use of the Rio Grande in the future development of the upper basin. 'the provision of storage capacity sufficient to regulate stream flow for adequate irrigation was the major problem. The use of water for irrigation constitutes practically its entire use. Froposed developments include reservoirs in Colorado and New Mexico. Two noteworthy sources of additional water are (1) importation from another drainage basin (San Juan) and (2) salvage of present wastes within the basin (consumption by native vegetation). Topography, geology, distribution, and rock texture significantly affect the water supply. Consumptive uses of water studies were made, and areas in agricultural crops and water-consuming native vegetation were mapped and tabulated. The San Luis Valley, the Midale Valley and the Lower Valley are described as to types of farms, climate, irrigation methods and other factors. By technical, detailed analyses it was found that as the Rio Grande flows southward its water becomes progressively more saline, a condition that affects the soil and plant growth. Studies were made as to the possibilities of importing and storing water from other basins in New Mexico and Colorado. This report is a factual base upon which a plan for the future development of the water resources of the upper Rio Grande Basin may be constructed. The physical, lezal, economic, and social conditions and relationships involved are numerous since this river is international as well as 
interstate in character. Wuch of the report is highly technical, and its use by the average reader is limited. As a guide for the preparation of water plans in other interstate drainage basins in the United States, it is excellent. Haps and technical drawings supplement the material.

Stream Improvement, "assachusetts Department of Conservation, Division of Eisheries and Game, Boston. April 1935. 5 p. mimeo. illus.

Many streams in Massachusetts have good conditions during the high water of spring, but no shelter to harbor trout in the low water of summer. On such streams, improvement dams must be limited in number because of the shallow flowage they would create over the bordering flat ground. Improvement most suited to this type of stream is to make holes, creating them by a method that will place them well below the stream bed which would give them a high value as refuges in a period of low water from drouth. The safest shelter hole can be made by using dynamite to blow a hole in the bed of the stream, under a bank where a tree or interlacing will hold the bank, or under a shelving boulder or leage.

Diagrams and drawings show stone, log or plank deflectors or barriers which protect such holes from drift or sediment.

This phamplet would be of use where conditions were such as those described in rassachusetts.

Ten Billion Little Dams, United States Department of Agriculture, Soll Conservation Service, tashington. 1939. 17 
p. illus.

Wise land use is an adaptation of nature's conservation and flood-control methods to the conditions of advanced cultivation. The principles are to make water walk or creep, to store a greater part in the soil; to do this by making the soil and its crops provide, as impedinents to run-off, millions of natural dams. Some of these reinforcements are: (1) Grass--anchors soil against erosion. (2) Trees--stay the Illow of running water and hold soil in place. (3) Strip--cropping. (4) Furrows--around the slope. (5) Terraces--cropland dams across the face of cultivated fields. (6) Dams--a natural aepression turned to form a pond or reservoir for building up both surface and underEround water supplies.

The work of conserving soil and moisture forms the heart of the Boil Conservation Service propram.

This booklet, witten on fifth or sixth grade level, could ce used in a study of the ways in which farmers may use every drop of mater.

Mhe Future is Ours, Franklin, Jay; Lodern Age Books, Inc. New York. 1939. $208 \mathrm{p}$.

This book demonstrates the importance of the IVA for the future of America. Going back to our reckless and ignorant abuse of the natural resources of the Great ississippi Talley (cutting of forests on water sheds, grazing of cattle and sheep, plowing up great areas of prairie grass and sod), and the resulting floods, dust storms, and droughts, $r$. ranklin shows how these affect the whole nation, and not only the immediate section where such devastation occurs. 
The great waste and loss to humen welfare, health, and happiness is stressed.

Historically, Fennessee has been the strategic key to the United States, and the Tennessee Valley was the logical place to make a start at the national control of the Ississippi Valley. This river drained part of seven states; the ralley through which it flows has heavy rainfall; the heavy forest growth on hillsides has been cleared away; the land has been over cropped; the region holds a treasure of limestone and phosphates; the people were dwindling in physical and intellectual vitality. This project is a challenge to America.

The operations of TVA--problems of ownership, leadership and airection, ulitities companies, political upheavels, and other corplexities-make an exciting story. The efiect of the WA on the residents of the Valley will be something for all of us to watch.

This survey of federal power activities as represented by the TVA is presented wi th keen logic and great economic and social understanding. It should be read by all adults concerned with their country's future weliare.

Cater, Its Conservation and Use, Morse, Stanley . Science Guide for Elewentary Schools. Tol. 3, No. 8. Werch 1937. $38 \mathrm{p}$

The rain emphasis in this bulletin has been placed on the use and handing of water for consumption by homans. Sources of nater, finas, and metho for curifying by (I) aeration, (2) sedinentation, (3) filtration, (4) chenical treatment, and (5) boiling are described. 
Certain sections of California have an oversupply of vater and others, especially the Ban Joaquin Valley and southern areas, have insufficient water. Therefore, provisions must be made to store the excess rainfall of the winter and to transport it to the parts of the state where there is a deficienc. California makes use of wells in the santa Clara Talley, reservoirs for storing water used in San Francisco, both ground and surface water in Los Angeles, and the Colorado River hueduct supplies water to a group of thirteen towns.

Aside from human needs and irrigation, other uses of water discussed are (1) as a solvent, (2) in chemical changes, (3) as a source of hydrogen and oxygen gases, as a moderator of climate, (b) changes in state (solia, liquid, eas) in relation to he ating and cooling plants (furnaces, steam, refrigeration), (6) convection currents (also in connection ith heating and ventilating).

This is an excellent bulletin for teachers to illustrate and supplement material used in the classroom. Each teacher can select the material she can use and adapt it to any grade level. Water as a demonstration medium has been stressed and the experiments require little apporatus. They can be carried out regardless of the teacher's scientific training. This should be a most helpful guide to any teacher concerned with water conservation and uses.

Naterways in Fall, Cornell Rural school Leaflet, New York State College of Agriculture, Cornell University, Ithaca. Vol. 32, No. 2. November 1938. 32 p. illus.

This leaflet describes how to make an aquarium, and how 
to care for it. Life-history charts are given for the more common water plants and water animals and fish.

If the school were equipped with microscopes, these water animals would furnish a most interesting study. The directions and care of the aquarium are excelient.

Waterways in Spring, Cornell Rural School Leaflet, New York State College of Agriculture, Cornell University, Ithaca. Vol. 33, No. 4. Warch 1940. 32 p. illus.

Practices of drainine everywhere that water collected in pools contributed definitely to hardships irom drought experienced in recent years. Fonds, wisely managed, serve es reservoirs to maintain an underground water supply, or drinking water for stock; or breeding grounds for bait minows, waterfowl, fur bearers or aquatic plants, Springs and streams are important on a farm. The sides shoula be checked by growth of shrubs and vegetation; riffles and pools on streams make for better fishing; poliution and enemy fish should be watched. Bogs and marshes can be profitable--as cranberry bogs, production of peat moss, shelter for wilalife, fur bearers. Guiet waters yield income through lease of fishing rights, fish useful as bait, food, sport (rental of boets). Another important source of income is the water mammal--mink, otter, muskrat, beaver, and others. Establishment of breeding areas, food, and protection against natural and unnatural enemies ill increase the number of waterbiras. Hunting privileges would then be a source of income. Profit derived from fross, salamanders, or snakes would be negligible.

This leaflet describes what may be done to improve wet 
places on the farm. It would have some value for schools, but the general plan is to help farmers and 1 andowners improve their farms--the ponds, springs, streams, etc. The graphs used would be difficult to use below junior high school level. 
A Gallant Fish Passes, East, Ben. American Forests. July 1937. pp. 334-355; 367-568. illus.

The richigan grayling is gone forever from the earth, or so nearly so that all hope of preserving him nay as well be abandoned. Once he vas abunant. Michigan did not watch hin pass without a struggle. As far back as 1378 the efforts of the state included it in its fish propagation propam. In 1902, 1924, 1925,1931 and 1956 efforts were made to obtain breeding stock, but in 1935 no fish at all were obtained.

What caused the rapid disappearance and final extinction of this isolated member of the grayling family, no one can say with certainty. Various theories have been advanced and it seems probable that several of them have a major bearing. Most commonly accepted is the contention that the cutting of Iichigan's vast pine forests resulted in changed conditions under which this delicate game fish could no longer exist. Another belief frequently advanced is that the driving of millions of feet of logs down the rivers destroyed the spawning beds of the grayling; cedar logs may have fouled the beds of the grayling with acids. Finally, riing anglers hold the opinion that the rapid spread of the eastern brook trout was fatal to the grayling. This article brings to mind the passing of the passenger pigeon, the heath hen; and the great auk. It is solemn warning of whet may hapen to other species 
if we do not act in regard to our wildlife conservation. All adults, interested in the future of our conservation program, should read with keen and alarmed note.

A Grand Tour of the Major Refuges, Where the Vildiings of the Air Find Sanctuary, Zahniser, Howard; American Forests. June 1937. pp. 287-292 111us.

we Americans in the past have had strange ways with our wild birds. Depriving them of their natural habitat and depleting their numbers for sport, we have been either heedless of conseguences, or else blindly trustful in some presumed Fower. Fortunately, the Federal Government has at last come to the rescue and is providing the birds with thousands of acres in every section of the country. It is not only acquiring areas but developing them for use of the birds and other wild1ife. The United States Department of Agriculture now administers about three million acres for wild birds. This may not be enough for an altogether ade uate proeran of restoration, but is is a forward step toward that end. whese areas (sanctuaries or refuges) afford portection from the hunter's gun, the plow, the ax, and the ditch-digger. They provide safety where wild birds can feed, breed, rest and winter. An armohair tour of these refuges shows the varied conditions and their diverse inhabitants. Briefly, the 75 refuges are described.

mitten in an interesting manner, this article woula be of great interest to a bird study Eroup. 
A Guide to the Fishes of Tennessee and the Mid-South, Kuhne, Eugene R.; Tennessee Department of Conservation, Division of Game and Fish, Nashville. March 1939. 124 p. illus.

The demand for a booklet describing the more common fishes in the state and immediste region has come from high school students, sportsmen, conservation officers and from educators. This bulletin gives the sportsmen a tool whereby almost any fish taken in angling may be iaentified; high school and college stuäents may use it as a text in beginning ichthyology; the information is concise and accurate. The rey to the families is as simple as is possible. External churacters are used wherever possible. Absence of many technical terms makes the key easier to use. Each family and genus is described. The illustrations and references are excellent.

As a guide for high school students and fishermen, the publication is very good.

A School for Game Protectors, Luttringer, Leo A. Jr. American Forests. December 1936. pp. 562-503; 580 illus.

Fennsylvania has removed the last political barrier to the protection and preserv tion of its tilalife. By establishing a permanent training school for all field personnel engaged in the administration of its wildife program, the state has closed the avenue open to politicians. The selection of student classes is one of continuous elimination, so 
efficiently conducted that the expenditure of money, time and effort is comparatively small. The training is academic and practical. The requirements and type of training are describad.

This program seems very fair, and very efficiently carried out. It should have a distinct bearing upon future wildife conservation programs in other states Which have grappled with the political problem. Conservationists and administrators should read with interest.

Are They Vermin? Cornell Rural School Leaflet, New York State College of Agriculture, Cornell University, Ithaca. Vol. 31 No. 2. November 1937. 32 p. illus. Let a skunk parade before a nature lover, a trapper, a poultry raiser, a gardner, a sportsman and a farmer. Each judges the animal on an entirely different basis. That is true of the skunk is equally true of the great number of birds and mamals which, for sone reason or for none at all, are considered vermin.

This leaflet presents the factst hat have been gathered about these creatures. The biras of prey, hawks and owls, are the topics under discussion. Charts give the description, range, ehavior, reaction to heat, light and moisture, man's interest for verious species of owls, hawks, blue jay, crow, Pox, mink, squirrels, rats, raccoon, bob cat and others usually considered vermin.

The discussion of havks and owls is very comple te 
and interesting. The material could be used by upper elementary and junior high students. The value of the chart is questionable since it would necessarily need to be re-worked in a form to present to children of any age or level.

Biennial Report of the Bureau of Scientific Research and Statistics, State of Louisiana, Department of Conservetion, New Orleans. 1936. 102 p. illus.

This report covers the biennium 1934-19.5. This Bureau has been called upon to answer inguiries from many of the leading conservation agencies throughout the country as well as various federal agencies. These reports included poisonous snakes, inguiries relating to fishes and pollution studies. In 1935 reports were received of disastrous oyster mortality in certain coastal areas adjacent to relatively recent oil developments. Field surveys and experiments were conducted. Evidence presented in the report showed that the discharge of oil into the sea produces profound changes in the nornal environment of the oyster. Such pollution may cause irreparable injury and desth of the oyster. From the point of view of conservation, natural oyster resources of the sea must be protected from this anger.

A very complete and interesting report on the black widow spider--its distribution, aescription, egg cocoon, habitat, behavior, bite, symptoms, medical treatment and control measures-are given.

In a report on shrimp, suggestions for realloceting 
the rishing intensity from the sm ll shrimp to the large specimens may be possible to increase the catch and value of Louisiana shrimp.

The statistical sumary of that state's natural resources is in the form of bar graphs and is easily understood.

This report tells of the activities of the Bureau. To those in certain business enterprises in Louisiana these reports would be of interest. Parts, especially the reports on the black widow spider and shrimp could well be used in schools by fifth or sixth grades. The statistics lend themselves to graphic presentation.

Diennial Report of the Game and Fish Comission, (for October 1933-September 1935) Mississippi Conservation Departinent, Jackson. $77 \mathrm{p}$. illus.

This report covers the progress and plans of the Comission for the preservation and increase, wherever possible, of the state's wildife reaources. These activities include (I) game surveys, distribution of certain fishes and other aquatic forms; (2) fish rescue trom stranded pools and shallow lakes, cempaign of education advocating more self-sustaining farm ponds for game fish; (3) cooperation with public relations (National Resources Board, THRA. Surveys and reclamation); (4) supplied collections of reptiles and amphibians to united States Museum; (5) propagation and scientific collections made for study; (6) press releases on open seasons and bag limits, issued monthly "Conservation News," issued other informetional data; (7) submitted projects for 
T.P. Alands to be fenced, recreational centers, rearing pens, hatcheries, etc.); (8) contacted fur trappers; (9) prepared three.reel movie of game and other wildife, exhibits at State Fairs, Museum unit arranged for schools; (10) restocking of game biras, animals, established one Gane farin.

This is a rather jetailed report of the plans carried out and those in propress in the game and fish commission of ussissippi. It gives a good insight to the workings of that body. Frovided ith more funds, the commission expects to expand their program. It misht prove helpful to like agencies.

Biennial Report of the Game and Fish Commission, loctober 1935-Septenber 1937) Mississippi Conservation Department, Jiskson. $25 \mathrm{p}$.

The activities of this Commission included (1) educational talks, lectures, movies for schools and civic organizations; exhibits at fairs; monthly publication "Game and Ish" issued; (2) extensive restocking of game and biras, fish rescue; (3) game refuges established; (4) publicity through newspapers and radio; (b) survey of feuna and flore of Hississippl started; (6) issued licenses for hunting and fishing and trapping; bought Prom trappers or hunters, all female raccoons to be released at end of trapping season.

of interest to the State Legislature, citizens of Mississippi, and other conservationists of wildifie, this report gives the progress, plans, and policies of the State Game and Fish Commission. 
Birds and Office, Superintendent of Documents, Tashington. Frice List 39 - 34th edition. JuIy 1959. $9 \mathrm{p}$.

This Iist of publications, releting to the above subjects, includes all the government moterial on those subjects. The prices are nominal--all 1.00 or less. The topics covered are voried. Nearly all the material is on an adult level, yet teachers could find some which they might use with their classes and as reference material.

Biras of Tennessee, (in Verse end Story) Craig, dohn L. Educetional Service, Depertment of Conservetion, Nashville. Uriated. pp. $3-75$ illus.

This booklet is a reader and work book containing facts about nesting habits, naming of birds, definitions of migrants and residents. There are also verses, stories, and descriptions of thirty rennessee birds. For each bird there is a space in wich to paste a bird picture. These sets of bird cards are made available by Church and Dight Co., makers of Arm and Farmer Soda.

The poems are cleverly written and should add to pupil interest. The accompanying stories are well written and contain many pertinent facts. The activity of pasting in the pictures will be appealing to chilared. The vocabulary is too dificult for lower elementery grades.

The booklet would be useful in the elementary grades (fifth or higher) as a supplementary reeder.

Colleges and Universities Offering Courses in Wildife 
Manggement, 1937-88, United States Department of Agriculture, wildife Research and fangement, washington. Leailet BS-98. October 1937. 8 p.mimeo.

In the Federal and state services and in the educational and research work of colleges and universities there is a limited demand for highly trained persons. The Iist of American educational institutions is segregated into sroups that offer (I) a full wildife curriculum leading to a degree; (2) a partial wildife course in connection with forestry; (5) a portial course in connection with agriculture; (4) elective wildife courses in connection with general zoology or biology. Institutions in the craduate field offer advanced students material organized from original sources, seminars and research problems.

This compilation of institutions assists students seeking informetion regarding graduate and undergraduete training in wildife management.

Conservation for that? Davies, F. A. The Kentucky Varbler. Vol. 17, No. 1. 1941. pp. 2, 3.

Interest in conservation and restoration of wildIife has increased in the past few years, but in all the magazines, newspapers, racio and other sources of material there appears to be no uniform aims and methods for a sound conservation prosam. The sportsmen are the interest group now forging ahead. Their aims are clear and they have financial backing; their interests are usually selfish end onesided.

Ornithologiets should and could assume a definite 
leadership. They shoula formulate a definite propam and work to ard its accomplishment. The proram should enter the schools as an integrated part of the suoject taught; clubs and business oreanizations chould be solicited for aid. The friendly spirit of the iarmer and stockmen should help to form a solid front for the protection of wildife, if educated in the correct ay.

Conservetion, restortion, and ise use os our mildIife can be accomplished by clarifying the aims and methods of auch a proram. The pIan needs organiration and education et work with it. This article elives en overview of the situstion and its possible solution.

Conservation Lams relating to lia ater Jowl, Biras ana Game, Warylona Game Jivision, Annapolis. Tol.z. 1987. $71 \mathrm{p}$

This compilation aefines ame, describes the various kinds of licenses needed in faryland, the uties of amewarkens and deputies, bac limits, seasons, penalties, etc. in reletion to upland end migratory ene biras ana $a m e$ animals, sone and insectivorous birds, wild vater fowl, boats, wck blinds, muskrat, raccoon, opossur, elk, and deer. Also included are the regulations pertaining to state sme refuges and hunting grounds.

This phamplet is published so thet hunters, trappers, ant the eneral public may know the laws of the state, end to enable them to cooperate in enforcine the conservation laws of the stete of Yaryland.

Cornell Rural School Leaflet, (Teacher's Murner) Tre Ner Tork State College of Agriculture, Comell University, 
Itiaca. Vol. 35, No. 1. September 1939. 64 p. illus.

This leaflet, for the teacher, gives the various orders and species of memmals (distribution, description, food, and uses or values/ commonly found in the United States and neighboring countries. The purpose of such material is to add interest to geography. The teacher could re-work the material for her children, or through the information given could collect materials on these memals as certain sections or areas were studied.

The second part of the leaflet aiscusses nature study as the foundation of sex education in the home and school. Sex education attempts to help young people interpret the various relation of the human sexes. The biological "facts of life" are fundamental, but the sex education is more than biology, because mental and social relations of the sexes play so great a part in the lives of educated people. Suggestions for developIng sez education through nature study are given.

This discussion may help parents and teachers answer some of the questions put to them by children. Great confusion is present in this problem. This is a good overview and one way of approashing the situation.

Doom of the Great Lakes Fisheries, Van Oosten, John Anerican Forests. March 1937. pp. 105-105; 144 illus.

The Great Lakes and their connecting waters are the chief commercial sources of our most highly prized freshwater species of fish. These species are facing extermination; yet little is being done to save them despite the strong national trend toward conservation. The Great 
Iakes account for all of our commercial proauction of such spocies as the widely advertized whitecien, loke trout, vall-eyed pike, yellori perch, blue pike, saneer, chubs, cisco, lake herring and suckers. Ls soon as one fishery is iped out, another one is threatened because the nets that had been employed in catching the exterminted species are aiverted to the capture oj other species. To renedy the situation, we nust reduce the present fishing intensity. The greatest single hendicap that confronts the adninstretors is devided control. The Great Lakes fisheries are not under the iurisajction of the Federal Government, but are administered by the eight states fronting the Great Lakes. Unless some firm action is taken, and taken soon, the productivity of the lakes that are stil supoortine a fairly large rishing industry will repeat the history of production of Lake intario.

This article foretells the depletion of fisheries in the Great Lakes, the seriousness of which is little realized by the public. Of interest to all adult ideanake citizens, especially those of the Great Lekes region, it informs the public of the situation.

Duck Fonds Versus jeserts, Darling, J. H. Rotarian Taeaine. October 1988. 3 p. illus.

Tat we have poured down the rathole much of that wich nature save us on this ragnificant continent is apparent at a casual glance. Our porests, of priceless value if we had them back today, have been hacked down and burned avay. Our rivers, wich onee teemed with ish 
and aquatic Iife, have become sewers to carry away the waste of our civilization. Our soils, richest in all the world, have been so abused thet millions of acres which once produced food and comfortable living for human beings, are now abandoned and becomin eroaing wastes, scars of heedless and prodigal existence of a few brief generations. Te have now come to the end of our frontiers.

on a trip covering the Mississippi Velley from the Culf to Canadian borders, a survey was made by the author, of the duck-recovery refuges. This was just a small segment of our national conservation problem; and the se projects were successful because conservationists got together and demanded 1t. Numerically, conservationists are thick, but not beneficial. Te have lots of conservationists, but little conservation, and our resources continue to disappear. And the strangest thing about conserv tionists is that they don't have to do the work themselves. A full corp of men is ready, but lack the means to accomplish their normal duties. Education is bady needed. We have the potential factors necessary if sportsmen and conservationists vill only organize and tell their story loudly enough.

Tritten in an interesting ana forceful style, this article is a rousing plea to conserve for the coming generations those ilalife resources of America intended to be a heritage for all. For the layman, it is interesting worthwhile reading.

Inter Eawk-Exit Mouse, Fough, Richard H. National Association of Audubon Societies, New York City. Circular No. 
24. Undated. $4 \mathrm{p}$.

In 1938 Reading, Fa. acquired a tract of about b,500 acres as a site for an impounding dam. In the next few years seedings of Red and Scotch Pine were planted. Toaay between the seedling pines, the former meadows have developed an ideal retreat for all sorts of small creatures. Various hawks and owls heve found the watershed a haven of refuge and bountiful source of their favorite food supply--the common meadow mouse. About this same time the city forester brought in a number of girdled pines. This damage, upwards of $40 \%$ loss, had been done by the meadow mice. It was not hard to convince the water bureau that more hawks and owls were needed. No more shooting of birds of prey was permitted.

This is typical of many sections of our country. Meadow mice girdle fruit trees as well, are a nuisance to agriculture, and eat the same weed seeds and grain that Eame birds aepend upon. The story of the meadow mouse and the vay its presence affects other living things is a typical example of the complex interrelationships that exist in the world of nature.

This bulletin does much to aid in the understanding of the complexities of neture, and the part that all animals (particularly birds of prey) play in relation to others. Such articles do much to dispell popular false notions of farmers, sportsmen, and the general public.

Essentials for More Bobwhite quall in Kentucky, Gilpin, James $K$. Kentucky Division of Game and Fish, Frankiort; 
Wildife Conservation Bulletin No. 1. Undated. 3 p.

Under normal conditions and barring unusual disturbances, about the same number of coveys will occupy the same range year after year. It is only by increasing the number of suitable areas that new coveys can be induced to establish themselves.

-Requirements for the existence of quail are (I) Cover --shelter, escape, feeding and nesting. (2) Food--insects, fruits and berries, weed seeds and greins, green leaves, buas. (3) water.

This folder will help the farmer and sportsmen to bring about better living conditions for our wilalife and give them the protection they need.

Finishing the Mammals, Adge, Rosalie; Emergency Conservation Committee, New York City. 1956. 24 p. illus. Pub. No. 59 .

Scientists state that the fur trade is definitely bringing to a close the Age of Mammals. Occupation by man of more and more of the environment avallable for mammals is contributing heavily to their extermination. Hunting, bounty payments, "control" campaigns, and "vermin" destruction are taking toll of these mammals. The United states kills more fur-bearing animals than any other country in the world. The cruelty and waste accompanying the use of the steel-trap is deplored. The gun and ammunition manufacturers and the trades that cater to "sport" have organized a campaign of propasanda against wild creatures. These campaigns describe hom certain animals prey upon others, yet scientific 
studies reveal that food habits are not of a predatory nature. The evils of bounties are described. The United States Biological Survey is soundly "rapped" for its use of steel-traps, and use of poisons.

This phamplet discusses the impending fate of mediumsized animals, those below the size of "big game," concerning the destruction of which the public is partially aware, and those above the size of mice and the like. It deals larely ith fur animals, including smell game, as oppressed by trappers, hunters, and game keepers. It should interest those in the fur trade, trappers, and those concerned with saving our fur-bearers.

Plorida Commission of Game and Fresh Tater Fish, Biennial Report) Tallahassee. December 1936. 62 p. illus.

Florial is preeninentiy an outdoor state. Its climate and inany netural resources plus other outdoor physical resources furnish the basis for much of the development and wealth which has made the Florida of today possible. The relation of these natural resources to Florida's future prosperity give a great importance to the Conservation of Natural Resources in this State. Florida's wildife resources have many values--aesthetic, recreational, and economic. Florlda's program for the conservation of wildife resources has been built along three Iines: protection, propagation, and education. The activities of the Commission included issuance of Iicenses, took game census, restocking of game (quail, wild turkeys and guineas), managed game preserves and refuges, fish hatcheries, soined lakes for rough fish; 
edited "Outaoor Florida," published a folaer on fishing, eave lectures before prospective teachers on conservation, assisted in exhibits, and cooperated with civic organizations and clubs.

This publication gives ar insight to floria's program of conservation. The prosram is based on sound principles, and, though handicapped by lack of funds, is working to promote conservation of milaife resources within the state. Phis is for adult reading.

Toods of Some Fredatory Fur-Eearing aninals of Hichisan, Dearborn, Ned; University of Iichigan, School of Forestry and Conservation, Ann Arbor. Bulletin No. 1. 1932. 52 p. illus.

The topography end flora of uichiean are suitable to acconoate a ereat aburance and variety of animal Iife. The fur resources of ichigan have declined, yet, in spite of these depletions, the state still ronks third among the states in fur production. one serious obstacle to any imrovement of the present situstion lies in the mide spread prejudice against many of our importent iurbearing animals because of their predatory habits. only two of the fur-bearers-muskrat and beaver, cen be called vegetarians; the other nine are largely or exclusively carnivorous. Fublic interest extablished the motive for assembling evidence to show the actual food hats of the aninals in question: opossur, raccoon, red fox, coyote, wiljcat, skurk, mink, weasel and badger. This investication lasted two years and studies of visceral contents an feces were made. "he results showed that chief food 
items of the animals were (I) opossum-fruit, flesh--mostly refuse; (2) raccoon--crawish, grain; (3) red fox--rabbits, mice, Pruit; (4) coyote--rabbits; (5) wila cat--rabbits; (6) mink (summer) crawfish, mice (tinter) muskrats, raboits, mice, fish; (7) weasel--mice; (8) skunk--insects, fruit, corn, mice; (9) badger--mice, rabbits, ground squirrels. Predatory animals in general are not especially dangerous to game birds.

As to the value of the annual fur crop, there can be no doubt. The evidence is submitted in the issue between those groups which would kill off predators, to protect game birds, and those groups which prefer to conserve the smaller predatory mammals for their service in destroying pests, their fur, and their recreational value. This bulletin substitutes facts for guesses and provides information essential for the wise management of one of Michigan's important resources.

4-H Club Guide in mildlife Conservation, South Dakota College and South Dakota Department of Game and Fish, Fierre. 195640 p.

In the 4-H program, conservation is considered in its broadest sense. Soll, trees, shrubs, home beautification, birds, maintaining water levels, wildflowers, insect control, rodent control and many other things are directly related to the general conservetion program. Activities carried on by 4-h Clubs may include a wildifie survey of the community and wat action is desirable in the carrying out of the propram, start a library of conservation books and bulletins, meet with local same varden, 
stage a public exhibit, tour, picnic, ect. to familiarize public with a need for conservation, keep newspapers informed, obtain and keep pictures of interesting activities, and have summaries mitten of all conservation work done. This is a guide $f$ or the Club as a whole. Individual activities might include planting of trees, leaving fence rows and strips of grain for feed, build feeding stations for birds, and so on.

This guide is especially designed for use in rural areas and the opportunities are varied and plentiful for a vildife conservation program. The program as outlined may cover several years work, and much good could be accomplished by such a program. Surely all 4-H Club leaders should possess this publication.

Gambling With the Ducks, Mmergency Conservation Committee, New York City. Fub. No. 82. February 1941. $4 \mathrm{p}$. The only safety for the waterfowl is to insure a sufficient breeding-stock. The Fish and wildife Service is under constant pressure for relaxation of all regulations. The sale of duck stamps has doubled in the last five years. The regulations now in force are too lax for safety. Four measures advocated are (I) no shooting anywhere after December 15th; (2) hunters of migratory birds linited to one geographical zone; (3) no more step-by-step surrender to pressure; (4) no open season on the wood duck. This bulletin informs the public of relaxing regulations when weather conditions favor waterfowl, and the decreasing of waterfowl. 
Game, Fish, Fark Laws and hegulations of Lebraska, Game, Forestation and Parks Comission, Lincoln. $1957.50 \mathrm{p}$. This is a compilation of laws of Nebraska as related to (I) definition $O \vec{i}$ eame and fish, (Z) permits to hunt and Iish, (b) open seasors and bae linits, (4) reserves and sanctuaries, (5) penelties and enforcenents. For any hunter or iisherman who expects to participate in the state of Nebraska, this booklet is essential. Game Vangenent on the Tarm, United States Department of Agriculture, ashington. Tamers' Bulletin No. 1759. october 1950. 22 p. illus.

Game manaenent makes it posaible for the farmer or lendowner to increase the number of game birds and mamals on his property, and bo doing to proauce benefits and regize profits thet wil reward his efforts. Game birds are anong the netural aias of the crop crower as they concure cutworms, Erasshoppers, caterpiliars ana other destructive pests, as well as weed seeds. In aduition to these benefits from the mere presence of the biras, an annul eake crop can be hervested from their increase. If by lanning, a property owner can combine on his land gane production ith crop production, and at the sme time control erosion, he is only doing what any good farmer ought to do to get the best use from his acreae. The actual steps in putting a came nanagenent plan into efect nust besin. Ith a survey of the ferm--crop area; non-crop areas such as fence corners, steep slopes, eullies, etc; pernanent cover ana food patches and temporary cover and food; sesk gevice of county agent, state ame comission 
or other agents; if no wild stock exists on the property, consult state gane comnission as to methods of stocking; game management noed not be a complicated nor expensive practice. Cover may be any type of low, thick-growing bushes, or vines. Tood may be waste grain or a smell bit of crop left staning, berries of shrubs forming the shelter or rains planted purposely for the game.

The future of uplend game shooting is in the hands of three agencies: the landomers, the state game commissions, and sportsmen and their ability to develop and maintain a system that will bring pronounced benefits to all. The Iowa plan is a good example.

This bulletin describes how farmers can manage the ir farms so that game will be more plentiful, realize cash from hunting privileges, and at the same time, prevent erosion of ditches and gullies. It is an interesting bulletin, simply written, for farmers and sportsmen.

Game Refuees and Eropagation Areas Add to Indians's Wild

Iife Program, Department of Conservation, Division of Fish and Game, Indianapolis. Undated. 4 p. illus.

This leaflet describes Indiana's program of propagation to insure good hunting in Indiana, and game management practices in both private and public lands. This program includes planting of grain, trees, shrubs for natural food and cover in areas where it is needed. The program also includes establishment of marsh and lake areas for migratory waterfom. Hin the game preserves are wildife aisplays and recreational facilities.

The leaflet describes the multiple aims of conservation 
programs--saving wildlife, recreation, and educational aspects. Other states seeking a similar program could profit by the use of the leaflet.

Game Returns to the Land of William Penn, Luttringer, Leo. A. Jr. American Forests. September 1936. 403-407 p. illus.

Today, Fennsylvania is famous for its wildife, as well as for its laws and policies governing wildife management. Forty years ago, when few men talked or dreamed in terms of natural resource conservation, the state awakened to a tragic realization. Its once abundant wildlife was diminishing, in some regions disappearing. In 1895 a Board of Game Comnissioners was created to determine the State's policies of wildife management and restoration. In 1897--the passage of a law prohibiting use of hounds in deer hunting; 1905--black bears were given protection; in 1907 femele deer and young males were protected; 1916 -the hunting license was authorized and "bounty law" passed; subsequent years saw all the game laws codified. Various Bureaus were created for acquiring land, establishing refuges, enforcing game laws, etc.

This brief discussion of Fennsylvania's gallant and successful fight for wildife recovery is interesting and noteworthy. It shows what can be accomplished by men of vision and purpose. It should interest all adults who have the future of their state at heart.

Game to Spare, Shantz, H. L. American Forests. December 
1937. pp. 574-578; 598; 608 illus.

To maintain fovorable conations for perpetuating bie game in the National Forests, the United States Forest Service has made game management an integral part of forest management. It is just as necessary to regulate the number of game animals in the forests and on the ranges, as it is domestic stock on a farm, or ranch. Balancing the herds with the feed production is the plain philosophy of game management. The normal amount of hunting in easily accessible regions usually takes care of surplus game. In less accessible or strictly protected areas, those responsible for the welfare of the game, and for other uses of the $I$ and, occasionally find the areas overpopulated, particularly with deer, and in a few localities with elk.

Instances in Flathead National Fark, Selmay National Forest, and in Utah, are cited as evidences where winter food was insufficient and heris had to be thinned. Current fallacies are (1) wild game is fading, (2) restriction of shooting is the only important principle of game and management. More people need to study the problems of same in relation to for

This article does much to clear up ideas regarding big game and management. This problem is not fully comprehended by the general public. For the aversge reader, much information could be gained by reading it.

Good References on Conservation of Birds, Animals and Wildflowers, United States Office of Education, Government Frinting office. Washington 1938. $11 \mathrm{p}$. 
This anoteted bibliogrephy is classified under the topics (1) meteriel for children and (a) material for teachers. Grade levels are given. All material is available Irom the United States Government.

since material usable with chilaren is dificult to find this list shoula be of great aid in compiling naterial.

Governing ilalife Development, Cassachusetts state Dolicies) Fassachusetts Depertment of Coneervation, Boston. Pebruery 8,1057 . 7 p. mimeo.

The purpose of establishing wildife areas in state forests is to protect, cultivate, and increase useful vilalife as a valueble resource of the forest. Whis will provide a place here it can increase to the point where it will overflow to the adjacent lond to produce nomal broeding stock thereon and in turn enhance the surrounding territory by benefitine the famer and proviaing recreation for the nature lover and sportsman.

The choice of an area to be aeveloped shoula be selected on the basis of locetion, roeds, valied topograph, vater supply, for a and fauna. It should be nepped. Development shoula be alone lines of iorest Iire protection, winter cover planting, food strirs and patches, pemanent food and escape cover, swand improvement, strest improvenent, census bi-monthy, protectea agsinst trespassine. aintenance activities dili. vary; ecch area is a separate probien.

This plan is part of assachusett's propem for conservation of wilalife. It should be read with interest by 
conservationists in other states formulating similar plans.

Happy Hunting Grounds of Tennessee, Tennessee Department of Conservation, Nashville. Undated. 28 p. illus.

This attractive booklet describes the various hunting and fishing facilities of the state. A wide variety of fish--trout, bass, bream, etc., hunting for quail, turkey, duck, rabbit, fox, wild boar all are available in Tennessee. Norris Lake, Reelfoot Lake, Cherokee National Forest, Cumberland River and various other streams are pictured and described.

Issued primarily for sportsmen, this booklet is also interesting to the tourist. Its pictures tell the possibilities of the state in all types of out-door recreation.

Eornes, Cornell Rural School Leaflet, New York State College of Agriculture, Cornell University, Ithaca, New York. Vol. II, No. 3. January 1938. 32 p. Illus.

The types of homes--temporary to escape danger; ancestrel (rather unusual in nature); apartment houses-pine cone illow gail; and their constructions as caves (woodchucks, weasels, minks, etc.) stone (caddis. worm, mice, snakes, trout, etc.l masons (robins, beavers, muddeuber wasp, cicada), wood (squirrels, woodpeckers, raccoons, etc.), weavers (birds, stickleback), and various other materials are described.

Not much home life is evident among animals, however, a few examples are given: (ants, bees stickleback, spiders, etc.) and discussed in relation to building the home, sanitation, storing of food, care of the young and pro- 
tection. Descriptions and suggestions are given for building and placing homes for wildife (bird houses, cover for quail, frogs).

This leaflet is a very complete presentation of the various homes of wildife. The key for nests of birds would be rather difficult for young children to use. The leaflet could be used by fifth graders and older children. Since little children are naturally interested in homes, the material could be reworked to their level.

How to Raise Game for Profit, Rockel, W. M. Jr. The Peters Cartridge Company, Kings Mill, Ohio. 1932. 47 p. illus. There is an ever growing demand for game on the part of hunters to shoot, people who want beautiful game birds for pleasure, hotels and restaurants for food, sportsmen for hatching eggs and day old chicks for raising purposes. This demand cannot be met now, but wi th auch a potential market, and good profit, many are becoming interested in raising game. This booklet describes raising pens, setting and hatching, care of young chicks, shipping of eggs and jay old chicks. It also gives an idea of how a farmer can increase his income by (I) providing food and cover on his farm, and increasing the game on his farm and (2) selling or leasing his farm for hunting privileges to individuals or sportsmen's organizations.

This booklet puts the raising of game on a commercial basis. It should interest those who like that sort of thing, and farmers who would like to increase their income. From a conservation viewpoint, little or nothing is gained from such a publication. 
Identification Key to the Reptiles Native to New Jersey, Scovell, E. I. New Jersey State College of Agriculture and Agricultural Experiment Station, Rutgers University, New Brunswick, New Jersey. July 1937. 15 p. mimeo.

Safety first rules are given for the person who is in a region where poisonous snakes may live. The copperhead, rattlesnake, yater moccasin, and snapping turtle are exceedingly dangerous, and the wise person should take no chances. First aid treatment in case of snake-bite is given.

The key, designed for use of 4 -H Clubs, is very simple. Little attention is paid to scientific classifications and terminology. The membership of classes, family groups, etc. are rather scattered. Once the name of the specimen is known, it is relatively simple to consult books for information on classification.

Because of its simple terms, this key is usable by the average adult or upper elementary student.

Improving the Farm Environment for vilalife, United States Department of Agriculture, Washington. Farmer's Bulletin No. 1719. January 1954. 61 p. illus.

Farm practice can often be modified so as to benefit wild things and yet in no way interfere with agricultural objectives. Cover for wild life is of essential importance. Concealing cover should be thick enough to afford some degree of concealment, though it should not be so thick as to keep game from maneuvering easily. Shelter cover and nesting cover are likewise of importance. Uniform cover conditions tend to limit the number of species, or the 
number of individuals, whereas aiversified cover increases the number. In addition to being aiversified, cover should be distributed--but not too widely. Distribution is particularly important as regards its location in relation to food. F'arm wood lots are valuable in producing fuel, lumber, conserving moisture, checking erosion, and as game production areas, for they contain most types of game coverts. The greater the variety of trees, shrubs, and vines, the greater is the value of the wood lot as a home for wildife. orchards, roadsides, marsh and water areas, anả marginal lands may be planted and developed as covers for wildife. Food supply must be a year-long chain. Summer is usually a season of plenty; fall and winter feeding is necessary. Flanting of shrubs, nut trees, leaving strips of grain, shocks of corn, and other areas are ways of increasing the natural food supply. Wilalife shoula be protected by the farmer in his operation of machinery (harvesting and mowing machines); reduction of the number of owls and havks may be feasible; management is necessary to control infections and parasitic diseases. Fossible returns from game management (aside from esthetic) may be realized by rentals, leasing, or other exchange of services between sportsmen and farmers.

This bulletin discusses how the farmer may encourage desirable wild creatures upon his lands, game species in particular, and how returns can compensate hin for altering his premises and policies. Milalife management has been referred to primarily as a game production undertaking, with purposes more or less secific and even 
mercenary. For the farmer who desires game as a "cash crop" this bulletin should be helpful.

Indiana Lakes and Streams Stocked rith Fish from State Hatcheries, Department of Conservation, Division of Fish and Game, Indianapolis. Unäated. 4 p. illus.

Briefly, this leaflet tells of the state's program for propagating fish. Indiana has 16 state hatcheries. Pictures show various activities carried out in hatcheries and at lakes and streams. Displays and recreational opportunities at the hatcheries draw interested sportsmen and offer educational possibilities.

of interest to sportsmen with the area, and to neture study groups or schools, the leaflet offers suggestea visits for plessure and study.

Insects of Nebraska, Nebraska Game, Forestation and Parks Cormission, Lincoln. Conservation Bulletin No. 5. Undated. $4 \mathrm{p}$.

Insects furnish material for one of the most fascinating branches of nature study. Grasshoppers, chinch bugs, coding moths, and others must be destroyed, but ruthless destruction of millions of useful insects has been responsible for millions of dollars loss.

A table presents the harmful and beneficial insects. This bulletin would be of special interest to farm boys and girls for they have great opportunity to study these insects and have great interest in their action and work.

International Committee Ior Bird Freservation, (4th Bulletin) 
National Association of Audubon Societies, New York City. 1935. 62 p.

This Committee first met in 198\%, for the purpose of devising plans for advancing the cause of wild bird preservation throughout the world. Subsequent meetings saw the adition of delegates from more and more foreign countries. In 1935 it was composed of members from 26 countries. Representatives told what had been accompIished by their countries. In the United states the report was concerned with the decrease in waterfowl as a result of drainage and drought, and plans for establishing water areas for ducks. Considerable progress had been made in Belgium for protection of game birds; Canada had done a good deal of educational work by issuing ornithological text books, lectures, newspaper releases and phamplets; in Gentral Germany a program for repopulating forests with hole-nesting birds was under way; in France, the only efficacious way of preservation for birds and ame is the predominance of private properties; Italy had passed laws restricting hunting seasons; bird protection in the Netherlands was very active; Foland had given legal measures and had carried out an educational program within the schools; in the Union of South Africa much conflict of interests was in force, and little had been accomplished.

These reports seem that gains in bird protection is rather discouraging, yet we must realize how far mankind has had to travel before acquiring even the interest that is today manifested in bird preservation. The exchanging 
of ideas and experiences makes for a closer association between people who have the same objects in vien.

This report should interest ornithological groups of our country.

International comittee for Bira Freservation, Fearson, T. Gilbert; Interrationsl Comittee for Bira Ireservation, Lew Tork Gity. "ay 1088. 5 p.

This adaress was given at Touen, Trance, by the Arerican representative to the Comittee. Fev countries south of the United atates eive any particular attention to the protection of wildice, and a fe huve no laws on the subject whatever. In efforts to contact people in Latin imerican countries mho might be interested in giving inforgtion reeraine bira protection or who rould Iond cooperetion in betterin the situstion, it as found there were very rew scientipic or orenized spontsmen's roups. Wections of the International comittee hev. thue for oreanized in fivo countries of the estern vemisphere-nanely Canede, mentina, exico, united states ais ono other (not ventionedimich has not been active. In the united atates restoretion activities in connection ith noesuto control, pollution of vaters by oil, establishing an bird bresaine forms, increase of wildeon supply, and law onforcoment regsures are discussea briefly. This report briefly sumarizes the setivities of the United etates in cornection ith the Interrational comittes for Mird preservetion. It icht interest bird study groups. 
Fentucky Game and Fish Laws, Division of Game and Fish, Frankfort. 1942. $27 \mathrm{p}$.

This is a compilation of Kentucky's laws relating to (I) Game animals (open seasons, bag limits, permits, traps, license fees and penalties); (2) mild birds (seasons, limits, guns, dogs, penalties); (3) Fish (method and time of take, nets and seines, limit of size and number, fish ladaers, licenses, penalties); (4) Mussels (Iicense, restrictions);

(5) Conservation officers and their duties.

This leaflet would be of use to hunters, fishermen, and trappers, wi thin the state of Kentucky.

Laws of the State of Indiana, Department of Conservation, Division of Fish and Game, Indianapolis. 1957. 108 p.

This handbook is concerned with the protection of fiish, game, fur-bearing animals, and birds. It gives the laws stating the powers and duties of the game wardens, licenses, game protective regulations, fish, frog, and mussel regulations, and the duties of the directors of the Division of Department of Conservation.

of value to the hunter or fisherman, the booklet gives the regulations for the state of Indiana.

Man's Friend: The Crow, Mmergency Conservation Committee, New York City. September 1937. 10 p.

Scientific stomach analyses have shown that crows destroy many insect pests that plague the farmer. They destroy insects in every nonth; they have voracious appetites; they search the whole farm for food; they find and attack infestations before the farmer is a ware of the danger; and they 
do it all for a modest fee in grain, chiefly corn. The Biological Survey made two exhaustive studies. The verdicts of these investigations are that in suming up the benefits and losses from food habits of the bird, the good exceeds the bad, and that the crow is a friend rather than an enemy of the farmer. bvidences of misdemeanors of crows are puling of seed corn, devouring eegs and young and pilfering corn in the milk; these are balanced by the benefits received from the insects destroyed.

In 1935 "Field and stream" created quite a furor by issuing a form letter in which canadian authorities placed the blame for the duck shortage on crows rather than drainage and droughts. Major articles began to appear in all sporting magazines, and such propaganda achieved its purpose for crow hunts and contests were held throughout the country. The influence of ammunition manufacturers is also a factor.

In 1934 the Biological survey reported that crows were confined chiefly to agricultural areas, and though doing some damage, their chief food was insects. Thus, the Government refused to take a part in the crow control work. This publication shows that the crow is the friend of man. Lack of knowledge on the part of the farmer, sportsman, anò general public accounts for misplaced zeal. If the time, money and energy expanded in crow killing campaigns were spent on the findings of science and research, real conservation would be accomplished.

Maryland Conservationist, Meryland Conservation Department, Game Division, iltimore. illus. 
This magazine is published quarterly by the Game Division. It is concerned with various game problems and current happenings in that field--wildlife administration, feeding grounds for quail, pheasants, rearing of quail, fishing, and other aspects of interest to the hunter, fermer, and the general public.

This magazine gives the problems and solutions as worked out in relation to the wildife of Maryland. Certainly of interest to Maryland people, it sets a good example for other conservation publications.

Osquito Control Operations in Tide Marshes in Massachusetts and Their Ifect on Shorebirds and aterfowl, Bradbury, Larold h. The Journal of Wildife Kanagement. Vol. 2. No. 2. April 1938. pp. 49-52.

Sportsmen and bird lovers reported that there was an alarming decrease in the numbers of migratory fowl that visit assachusetts marshes juring their migrations. In hay and June, 1936, the Conservation Department chose the juxbury Marsh as the experimental area to conauct a fact-finding investigation. Frior to 1931, when mosquito control operations were completed, many difierent species of migratory fowl had been observed, and on several occasions flocks of American egrets tarried for at least a week. In the survey, the shallow water mud Ilats were found to be completely drained, with the bottom aried and cracked. No birds were observed. A plan was worked out with the rassachusetts Reclemation Board to recreate an environment favorable for shorebirds and waterfoml, and at the same time check mosquito conditions. 
From this report, it appears that a program of migratory wilalife restoration can be carried on ithout impairing nosquito control. This report should be valuable to other states having a similar problem.

Fropagation of Pheasants and Quail, Cottingham, H. P.; Indiana Department of Conservation, Division of Hish and Game; Indianapolis. 1954. 24 p. illus.

Given are detailed descriptions of laying pens, care of eggs, hatching, and rearing of both pheasants and quail. Measurements, materials, and diagrams give adequate instructions for building necessary equipment. The food to be used and a aiscussion of sanitation and diseases are included.

The purpose of this bulletin is to aid farmers and sportsmen in the propagation of pheasants and quail, the results of which will aid in keeping these game biras stocked in the woods and fields.

Quail Breeding Manual, More Game Birds in America (a Foundation), New York City. 1955. 55 p. illus.

This manual is a complete and detailed description of breeding quail in confinement--measurements and directions for building laying pens, brooder; care of quail during laying season, handling of eggs, hatching in incubators and with bantam hens, and the rearing of the quail are given. This information would be useful to the various quail farms, and any others interested in the rearing of quail.

Quail Management in Maryland, ilson, K. A. Conservation Department of Maryland, Game Division, Baltimore. February 16, 1938. $11 \mathrm{p}$. 
This report covers the manggement results and technical experiences of 27 month's work on 5,367 acres near Salisbury, maryland. The plan of mangeement carried on a study of food habits which showed that fall and winter quail foods of variety and hith nutritive value were scarce; the bulk of fall and winter food consisted of wax myrtle. Feed patches were planted to Lespedeza and pertridge peas. A census was taken. A Game Food Nursery experimented with various herbaceous Iegumes. A summary of results found: (1) that on the Eastern Shore of Maryland submarginal land is especially well adaptable to multiple use conditioning; drainage creates better forest growing conditions and likewise livable habitats for quail and other wildlife; cultivated land strips that grow food for quail also provide fire protection of the forest; (2) good drainage and substantial fall and winter food contributed to the increase of quail; (3) where optimum escape cover exists, predator control is unnecessary; (4) land cultivation increases food supply of predators; (5) plant transition from cultivated land to broomsedge in three years in acid soil; (6) other results are concerned with transition of plants.

since this report is rather techical its value to the average reader is doubtful. It might be us aful to the expert concerned with a similar study elsewhere.

Spiders and Their Kin, Cornell Rural school Leaflet, New York College of Agriculture, Cornell University, Ithaca, New York. Vol. 30, No. 2. November 1936. 32 p. illus. The best way to learn about spiders and their kin is to watch them. Some may be living naturally in the school 
room or house; others may be stuaied better in class if they are in a handy container. A description of such containers, easily made, is given.

This leaflet describes how spiders travel by web bridges, streamers, running, or jumping. Spiders capture their food by their various kinds of webs. Spiders have a courtship and mating period; the young and their care is described. The enemies of spiders are myriad--birds, wasps, etc. and how spiders protect themselves is interestingly told. The role spiders play in the general economy of living things is suggested. Iife-history charts in the leaflet tell briefly of the kin of spiders--characteristics, range, reproduction, habits, behavior, interest to man. This is a complete and accurate account of harmless spiders--how they live and their behavior. For lower elementary grades the teacher would ned to re-work this material but fifth and sixth graders could make use of it themselves.

"Sportsmen's" Heaven is Hell for Ducks, Brent, Irving, Imergency Conservation Committee, New York City. Pub. No. 71. June 1938. 12 p. illus.

Sportsmen are becoming more and more vocal in their efforts to bring back baiting and live-decoys. Their argument centers on a reported increase in the number of waterfowl in North America. Granted that a $25 \%$ increase has occurred in the last four years, that does not warrant any relaxation whatever in hunting regulations. Abolition of baiting and live-decoys has educated millions of Americans to the evils of these two methods. Cited are the in- 
fluential Illinois Sportsmen's Assoc. and organizations in region of Chesapeake Bay which have monopolies on waterfowl hunting. These have political influence and are constantly agitating for relaxed regulations. The attitude in Congress toward wildife is improving, year by year. In the main, it has become more conservation-minded. For the gdult, this makes interesting reading.

Tennessee wildlife, Caldwell, J. C., Bailey, J. L. Department of Conservation, State of Tennessee, Nashville. Bulletin No. 4. 1940. pp. 1 - 30

Tennessee has a comprehensive wildife program underwey based on cardinal principles of (I) research, (2) education, (3) law enforcement, (4) restocking.

A clear statement of the eims of the state for restoring Tennessee's vilalife is given. Given are the causes for the disappearance of willife, and value in recreation, economic, and physical wellbeing of the people.

It contains illustrations and descriptions of food, cover, protection and value of common eame fowl and fur bearing anims ls to be found in femessee at the present. The phamplet is presented in a simple readable, interesting manner. It gives a very good discussion of the causes of the disappearance of vildlife.

It can be used by the layman and would probably be of most velue when used in connection with education of the public in the "whys" of conservation.

The Biggest Game Freserve, Butler, Lorine L., American 
Forests. September 1938. pp. 402 - 407 illus.

In 1907 the Canadian Government set aside an area 4,200 square miles, and called it Jasper National Park. In this area of mountains and valleys, both biras and animals are protected. Many which were disappearing from the region have staged a remerkable comeback. The Rocky fountain goat, big-homed sheep, moose, deer, elk, grizzly bear, beaver, mountain marmots, squirrels, and Canadian jay are a few of the animals and birds. The stories of their antics around camps and the town of Jasper make interesting reading.

For the adult who has any interest whatever in wildlife, this article is vell written.

The Black idow Spider, United states Depertment of Agriculture, Bureau of Entomology and Plant uarantine, Division of Insects Affecting Man and Animals, vashington. E-345. April 19.5. 4 p. mimeo. illus.

The apparent great increase in the prevalence of the black widow spider (Latrodectus mactans, Fab.) has aroused great interest, and some alarm. This species is to be found in practically all parts of the country, although it is more prevalent in the Southern States. It seldom enters houses, but frequents out-sheds, moodpiles, toilets, manholes, and siniler pleces. It feeds normally on insects and other small creatures. Its appearance and size are described.

The bite usually causes a stinging sensation, followed by sharp pain and swellins. The pein proeresses, the body becomes rieid, breathing irregular, and muscular contractions. 
First-aid consists of opening the bite with razor blade to induce free bleeding; aply disinfectant. If severe pain is felt, a doctor should be called without aiting for further developments. A definitely technical procedure for doctors to follow is given.

Since any individual may by chance be bitten by the black midow spioer, he should have a knowledge of where they live, their habits, appearance, and a knowledge of the bite and treatment. The leaflet is simply witten and contains useful information for all.

The Conservation of Native Biras, Conservation week in Schools of New Jersey, 1959 ) New Jersey State Conservation Cormittee, Trenton. $15 \mathrm{p}$. $111 \mathrm{us.}$

New Jersey has about 250 species of native birds. Bira structure as reloted to food habits, (as ducks have webbed feed for swimming to obtain food), are described. Bird banaing and migration are discussed. The good done by birds in eating insects, rodents, pleasure from their Eongs, as food and sport for man are some of the reasons given for protecting birds. rays of attracting birds to homes, schools and communities are by special provisions of food, water and shelter.

Activities for studying birds are tield trips, building bird houses, planting seeds for food, and providing water and bird baths.

In this publication conservetion of biras through citizenship training is emphasized, and with chilaren, this is important. This material is very good for teacher use, and offers a varied and vorthwile study of biras. 
The Fishes of Nebraska, Nebraska Game, Forestation and Parks Comission, Iincoln. Conservation Bulletin No. 2. Undated. 4 p.illus.

Nebraske is not a state of large lakes or deep rivers, but it does have sandhill lakes, sand pits, rivers and ponds. Conservation of these lakes and streams and the fish in them is one of the great problems of today and a matuer vital to every boy and girl of the state.

State laws provide thet fish (except in the Missouri River) may be taken only with hook and line. "Bait casting", "fly fishing," and "pole fishing" are described. "Closed seasons" are defined and reasons given for such regulations. Fish to be found in Nebraska are trout, sunfish, black bass, catfish, perch, cropples, rock bass, and pickerel.

This leaflet would have great interest for ten year and older boys, whose natural interest in fishing would be heightened. On their reading level, it is interestingly presented.

The Native Mammals of New Jersey, (Conservation Week in Schools of New Jersey, 1940) New Jersey State Conservation Comittee, Trenton. 15 p. 11lus.

Hell known by name and familiar in varied ways are the mammals that live around us. Mammals have definite relationships to man upon which the need for conservation is based. Wach plays its jefinite part in maintaining the balance of nature. Some mammals are valuable as fur-bearers. Mammals have numerous external and internal structural characteristics. The uses of a few of the external characters and the 
adeptations of these structures are considered (bushy tail of fox which it uses as protection from winter cold, sharp teeth of rodents, etc.). The various types of homes and foods are discussed. Rabbits, mice, foxes and other animals may often seriously damage crops and property. ays of control are given. Care of marmals in the classroom for study is described.

This leaflet, for teacher use, gives some very good source material and suggestions for a stuay of mammals. The level is not given but each teacher might select her own approaches and activities. The bibliography is up-todate and adequate.

The Freservation of Native Plants, (Conservation Veek in Schools of New Jersey, 1937); New Jersey State Conservation Comittee, Trenton. $15 \mathrm{p}$. illus.

New Jersey has three broad geographical areas; the differences in elevetion, soil, climate, etc. produce a rich and veried flora. Hild flowers are fast disappearing because of industrial and commercial development, farming, lumbering, grazing, and fires; these are inevitable wherever man goes. Laws have falled to preserve the wild flowers. Bstablishment of Vild Flower sanctuaries and educating the the public seem to be the obvious vays of preserving these in the future. Agencies interested in native plants are the State Department of Conservation, State Museum, Garden Club of America, Mild Flower Preservation Society, and nunerous other civic groups.

Field study is the best way to know and appreciate wild flowers. Each teacher is urged to make field trips in a 
study of wild flowers.

This manual for teachers gives the basic principles of why wildflowers should be protected, destroying forces, and the flora of New Jersey. The material is adaptable to any grade level, and should be helpful. The bibliography is very good.

The Relation of Wialife Conservation to Agriculture, National rilalife Federation Bulletin Vol 4. No. 4. Tashington. April - May 1939. pp. 4-5

Tildife has a distinct economic value--in ammunition, fishing tackle, guides, clothine, etc., and this expenditure provides work for many people. the fermer is in large measure the producer of wildife. In an aericultural nation it is inevitable that wild things must be produced in conjunction with aericultural pursuits. Galle produced on the farn furnished the great bulk of the sport for hunters, and the manacement of those farms spells success or failure for the game that must look to the farmer for food and shelter. The Dept. of Aericulture, Biologicel Survey, the soil Conservation Service, and the Forest Service all are cooperating with the $\hat{I}$ rmers in advising them of practices which may be adopted under their program to provide greater benefits to wild life. Iikewise control of species of wildife which are injurious to aericulture is an important feature of the administration of wildife.

This article shows the pert famers can pley in preserving our wildife, and also benefit from it. of interest to farmers as well as others interested in ild- 
life conservation, it is interestingly written on senior high school level.

The Value of Predatory Mamnals, Hamilton, w. J. Ir. New York Zoological Society Bulletin Vol. 1. No. 2. MarchApril 1937. pp. 39-45 illus.

A belated effort is now being made to restore and conserve the wildife of our continent. Research on fundamental wilalife problems has been started and the results of these have dispelled many popular notions. But one persists--the mistaken premise that preatory species, "vermin," are not compatible with the natural increase of game species. Fredators are ruthlessly destroyed on the assumption that their decrease will witness a revival of same. Fev realize the interdependencies which exist within the oreanic worla. No animal or plant can live unto itself. This intricate interconnection, we comonly call the reb of Life.

This article is confined to four widespread predatory mammals--coyote, fox, skunk, and weasel. Stuaies show that the chief food of coyotes is small rodents and insects; of the fox--fruit, berries, smsll manmals; of the skunk-insects, fruits and small animels; of the weasel--rlesh (f1eld mouse) and a few insects. These studies do not reveal these animals to be a very serious menance, though they do kill game upon occasion. Studies of ducks, and grouse show that not all animals comonly suspected of being hostile actually are. Therefore, perhaps no animals shoula be classed as vermin.

We can credit racial sanitation to the predators by 
their culling of the weak and unfit. Every state is aware of the value of furred predators, and protect them while their fur is unime. Finally, among the assets of predatory animals: is their recreational value.

This article is one which helps dispell the widespread condemation of these valuable mammals. On adult level, it mekes interesting and worthwile reading.

The Taterfowl and Common Sense, Brant, Irving; Emergency Conservation Committee, New York. Pub. No. 64. 1937. $12 \mathrm{p}$.

Sportsmen say that arainage, arouth, botulism, alkali, oil pollution, crows, sea gulls,foxes, Mexicans, Indians, and muskrats are killing waterfowl. Never a word is said about the degaly barrage poured from millions of shotguns in the hands of millions of hunters. If waterfowl are not to aisappear fror the continent of North America, action must be taken along two lines: (1) a long-range program must be undertaken to furnish waterfowl with a protected habitat; (2) shooting must be stopped wille a breeding stock is built up. Soth of these necessary steps fall within the province of the United states Biological Survey. At the present time the Biological Survey has for waterfow protection, the personnel in its history. The survey oficials have taken a number of steps which show that they understand the plight of waterfowl and want to work effectively against extermination. Yet the steps they take are never quite adequate to the situation as it levelops from year to year. There is a puzling inconsistency between the Biological Survey's knowledge of the crisis on the one 
hand, and the ineffectiveness of its policies on the other. According to a Canadian chart $9 / 10$ of the waterfow are gone. The latest protective steps--shortening the season and abolition of baiting and live decoys, are progressive ones. But in order to preserve uaterfowl, the season must be closed.

In this phamplet significant facts about the existing waterfowl situation are given. Sportsmen are loud and powerful in their clamor for continued shooting. This is a plea for public-minded citizens to express themselves. For adult readers, conservationists and ornithologists, this is interesting reading.

The vild Turkey, Simmer, John T.; Field Nuseum of Natur al History, Chicago. Leaflet No. 6. 19:4. $15 \mathrm{p}$.

one of the first forms of wildlife to attract attention, in the early days of exploration and settlement in America, was the wild Turkey. Fowever, with the coming of the white man, the turkey began its retreat and gradually retired to the wildernes, a retreat which has gone on steadily and wi th varying rapiaity.

It has been assumed that the bird was a domesticated one, decended from the Hexican race. The source of the name is in doubt. Certain writers assumed that it came from Turkey, from whence the name. The most logical explanation is that certain of the bira's notes resemble the syllables, "turk-turk-turk."

Ihe plumage, hone, food and nesting habits are described.

Inemies of the rild lurkey are many--wolves, foxes, 
raccoons, opossums, hawks, eagles, Great Horned Owl and man. The Turkey has been used as an article of food and object of the chase. Many are the devices and methods of pursuit.

Few atternpts have been made to re-introduce the wild Turkey as a game bird into any of its former haunts. The disappearance of the species has been aue largely to the diminuation of suitable ranges and the unfavorable conditions still remain. Nith the passing of the wilderness the bird has retreated to less inhabited regions. Although not yet extinct, it must be classed with our vanishing game birds.

Simply written, this leaflet tells the story of what has happened to the rild Turkey. Conservationists should take note--what can be done?

Thirty-tirst Convention of the International Association of Game, Fish and Conservation Commissioners, International Association of Game, Fish and Conservation Commissioners. August 1937. 68 p.

In 1937 this group met in wexico City, where many papers were presented--migratory biras and international protection, vilalife problems on the boraer, American and Mexican National Forests, education in wildife conservation, and progress made in wildlife problems. These papers are not technical, but are of administrative nature and mean little to the average reader. For the research student, or legislative committee, they might be of help.

Three Seasons at Fawk Lountain Sanctuary, Broun, Naurice; Bnergency Conservation Committee, New York City. Pub. No. 
61. 1930. $9 \mathrm{p}$.

In 1954, Hawk Mountain Senctuary, in eastern Fennsylvonia, became the first sanctuary in the world for the birds of prey. It was acquired by the A.C.C. and covers over two square miles of the mountain with the strategic shooting sites. Gunters protested, but to no avail. Cameras and field glasses have supplemented the shot-guns.

In operation three seasons, the sanctuary has been visited by people from twenty states, Canada, and several foreign countries. Funters who formerly slaughtered thousands of these birds, many of them beneficial, now use the sanctuary as an observation post to study their characteristics.

Studies and census' show the trends of hawk migration-volume and flight-direction governed by the wind; heaviest misrations preceded by marked meteorological aisturb nces in the regions of the nor th; sequence of species is discussed and correlated with food habits.

This phamplet tells of the accomplishrent of one project of the committee, and the resulting data and recreational aspects.

Utilization of Rock Exposures for Den and Escave Cover by Raccoons, Giles, Le Roy ${ }$. The American Mill nd Naturalist. Vol. 27, 10. 1. January 1942. pp. 171-176

The raccoon is generally considered to be a treedenring aninal, and throughout most of its range this seems to be the natural condition. Studies associate a general decline of the raccoon population ith the destruction of hollow trees. In the absence of den trees raccons are known to re- 
sort to ground dens. In central Iowa drainage tiles are frequently found in use. In eastern lowa, Dubuque County, it was learned that raccoons were denning in linestone bluffs and apparently giving preference to this type of aen to the customary hollow tree. The investigation covered a nine monthperiod in 1938 and on occasionel visits in 1939 and 1940. The valley bottoms and flattened hilltops of the region are pastured or cultivated while the hillsides are mostly in timber. Consequently, as the bluffs are surrounded by trees and wods, the raccoons remain in contact with their habitual cover.

An abundance of available dens in this region is one of the most important factors influencing the annual production of a considerable number of raccoons. The maintenance of a high population reflects the adequacy of the environment, for raccoons are subject to an extremely heavy hunting pressure.

of interest to the hunter and conservetionist, this bulletin describes the adaptation of the raccoon to environment.

What is Heppening to Birds in Ean-America, Internetional Comittee Ior Bird Preservation, United States Section, New York City. $4 \mathrm{p}$. Illus.

In most of the islanas and countries south of the United states song birds nay be shot, netted, or snared, and nowhere are there laws limiting the number of game birds that may be killed in a day. Forty-five kinds of shore-birds receive no protection after they leave our borders. Gixty-seven species of our warblers spend six 
months in countries where little or no effort is made to protect them.

Some encouraging results are being seen in some countries where the Ean-American Section of the I. C. for B. F. is working to correct these conditions. Forty years ago the United States began pioneering in this fiela, furthermore, we can never hope to rebuild a natural level of supply of migratory waterfowl and shorebirds mithout the cooperation of these southern countries where so many of these birds spend six months of every year. This is an international problem.

This leaflet gives a group of facts not generally known, and recognizes the importance of encouraging and helping the southern countries for their own, and our interests.

What is Happening to Game in Florida? Partriage, Sarah. The Journal of the Florida Education issociation. November 1957. VoI KV. No. 2. pp. 3, 5, 6.

The wild turkey found in Florida is pitted against heavy odds--more hunters; modern weapons; good rogds, fire lanes, etc. make breeding grounds acessible. There is a steady diminishing of the bird.

The Florica deer is fast disappearing, and bills to punish law violators and limit and shorten the hunting season failea to pass.

The Florida bobwhite is disappearing and the state should give thought to shortening the hunting season and to rarms for protection and propagation.

This article gives an idea of trends in conservation 
matters in Florial, and the use of wildife resources in that state. It could be of use to conservation groups and others as material to influence legislative action in that state.

Where Game Laws are Needed, Fearson, 1. Gilbert, International Comittee for Bird Preservetion, New York City. Narch 15, 1937. $6 \mathrm{p}$.

This Committee engaged in a plan to secure informetion regerding bird protection or the $l a c k$ of it in inst Indies, Central and South America. The results of their findings were: (1) Puerto Rico--35 species of birds protected (useful to agriculture-no game wardens); (2) Dominican Republic - -illegal to hunt game birds and nammals for seven months of each year; prohibited to hunt quail for five years (193528); song biras protected at all tines; (3) Haiti--no laws; (4) Cuba--open season six months of year; (5) Barbados-no Iams; (6) Republic of Panama-no laws; (7) San Salvador-use of slings prohibited, hunting of game prohibited during periods of reproduction; (8) Nicaragua-no laws; (9) Honduras -no laws; (10) Ecquador-no adequate laws; sanctuary $f$ or wildife created on Galapagos Islends in 1935; (11) Feru-no lews; (I2) Chile--hunting permitted six months of the year; (1.) Colombia-no laws; (14) Bolivia-no laws. Because of the migratory birds which spend the winter months in these countries, for th American conservetionists heve a vital interest in these matters.

This information would be of interest to ornithological groups. 
Iila Animals of Nebraska, Nebraska Game, Forestation and Parks Commission; Lincoln. Conservation Bulletin ro. 3. Undated. 4 p. illus.

Vany wila animals that once were found in Nebraska in considerable numbers have disappeared entirely or are found very rarely. With certain destructive animgls such as the timber wolf this is a good thing. However, with such animals as the deer, badger, and skunk, their geing is a distinct loss.

Boys and girls can best learn about animals by seeing and studying their habits and.way of life. A table of rodents and other small animals and the nature of their habits is given.

This leerlet on fifth grade level is interesting and presented in good form. In a study of wild animals it should prove helpful.

ildlife and Cycles, ing, Leonard; $A$ erican Forests, October 19:7. pp. 496-498, 512 illus.

It hes been discovered that periods of scarcity and plenty in some species of game animals alternate with each other; such recurring periods are called cycles. E. T. Seton gathered evidence of cycles and called them "the ebb and flow" of animal lire. Aldo Leopold and Charles Blton recently gave vitalizing impetus to cycle thought. Geographic thinking shows the $t$ ame populations in widely separated areas may fluctuate synchronously, they may show different cycles in one part of the range from those in another, or they may be cyclic in one part and essentially stable elsewhere. The time intervals between similar 
nenifestations of e cycle are not strictly a efinite. They hove un averase length, although the ectual Ienth may shift about the average.

"any records of bira mi rations vave been made ard iend themselves yell to a study in cycle work. Iopuletion isuros are not easily ontained nor are thoy alvays scorate. The relationship between solar and torrestrial cycles sems weII established.

e hove so far regulated hunting seasons on tie assumtion thet the next year ill be like its predecesor. The losicel thing por us to do is to find out whot causes the upsing of the cycle onc to put it in oreration to raise the populion or smooth out the levs. Te should consider the cyoles in our manesenent and aduinistretion.

This article should be of interest to the ornitholosist, and conservation committees of legisletive neture.

\section{Wilolife and the Iand: A Stcry of Rezeneration, United}

atetes Government Frinting ofice, ashineton; 75 th concess, First session-Comittee Irint: Jenete. Januery 1837. 90 p. Thie is a report on the snecial counittee on conserva-

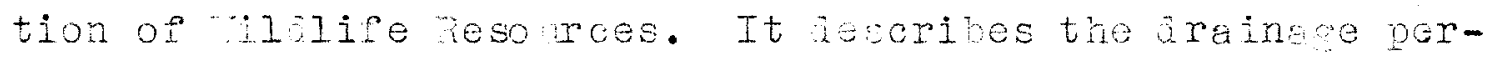
iol in the early $1900^{\prime}$ s folloved by the aroughts of the 1050 ' when tremendous aress of whet led boen importent nesting erounds in the north, rest aress alons tho ryways, and wintering resorts in the bouth wene rred up. reat dopletion of aterfoul resulted. In 194 enengency finis for waterowl restoration vere sporoprited. It as deciaed to acuire and restore as nearly as possible to their original state, perts of tho ereat ack-betchery region of 
the Northwest. The Upper Souris project in North Dakota in typical. The structural improvements were completed first, and then habitat improvement projects were undertaken. Vaps showing the dominant vegetation on various parts of the refuge were made. Planting of seedlings, nesting islands constructed, cover ana food were cared for, and al so provisions made for upland same. Other refuses throughout the country are described in detail. At the same time wildife is being regenerated, cover and protection is being provided to check soil erosion, streams are kept clean, silting is decreased, and the benefits are multiple.

This report gives a comprehensive and understandable picture of the problems of wildife restoration and manaéement. This report is rather long and not particularly interesting to the average reader: it is really issued to be of aid in supplying information for future legislative prograns to restore and perpetuste our wildife resources.

\section{ilalife Conservation, Gabrielson, Ira 1. The acmillan} Company, New York. 1941. 46 p. illus.

The various programs for the conservation of soil, water, forests, and wildife are closely interwoven. This interdependence of conservation programs is definitely outlined. Conservation of both soil and water is basic to wildife, and to the needs of the human race as well. Wildlife stands to gain in any rational conservation program. Water conservation will make possible an abunance of fishes, fur-bearing animels, and aquatic birds--all of winch are important to man. Forest conservation and wildile are closely related. For the past few years forestry practices based 
on the concepts of multiple-use and sustained yield have been emphatically to the advantage of ilalife. Grassland restoration should go hand in hand with a definite program for the restoration of uilaife.

Specific problems are varied and nany. Every area is derinitely limited in its cepacity to produce big game. Basic requirements are the same for resident and migratory birds and animais--sufficient and suitable cover and food. Fur animals are a potential source of revenue thet can be greatly increased if more knowledge is gained, and if a system of governmental control of trapping on public lands is established. Nongame birds and animals are considered valuable or abjectionable only as their habits affect man's interest. Rare and vanishing species are the result of geologic changes and ran's interference. Refuges have a definite place in conservation but much more research on management is needed.

Soil, water, forests and wildiffe are only parts of one inseparable program; ildife must have suitable environment, and any use made of any living resource must be linited to not more than the annual increase. Throughout this material great stress on the interlocking ramifications of conservation is made.

witten in simple terms, this material acquaints the layman with the basic principles of conservation, and should help in the restoration program through this knowledge. For the adult, this is easy, readable subject matter.

Vildife Crops, Anerican Vildife Institute, ashington. 
1936. $23 \mathrm{p}$. illus.

The American Hilalife Institute, in cooperation with the United States Bureau of Biological Survey, $\cong$ ame and fish departments, and the land rant colleges in nine states, initiated a research and demonstration proram in wich it is developing accurate facts and effective methods wich may be profitably applied by the interested rublic in incresing the annual crop of wilalife on the land itself.

All species of wilalife can be produced in the wild by improving their enviromment--by increasing the carrying capacity of their range. I'o improve range there must be exact knowledge of what each species needs--kinds and amounts of food and cover in each sesson, what enemies and competitors it will tolerate. To learn how to appraise and improve rance is the job of research.

Briefly, the program of research needed in relation to farm, forest, and range game, migratory game, fish, fur, rare game (grizziy bear, bighorn, caribou, peccary, etc.); non-game (condor, ivorybili parakeet, etc.); and milaflower is discussed.

The going program, consisting of the nine agricultural college units established, deals meinly wi th farm game.

This bulletin stresses the importance of research in wildife management. Wuch needs to be done, and progress is necessarily slow.

This bulletin should interest institutes and organizations able to sponsor research, and students who have the ability and desire to do research.

Hildife Report, (Iestern Shore Froject), Vaugh, H. A. 
United States Department of Agriculture, Nashington. February 1928. 6 p. illus.

In 1936 this project in Maryland was begun to develop wilalife in this area of nearly 7,600 miles, of which five percent was allotted to wildife. The conversion of old homestead, barnyard and sammill sites to permanent game food patches seened advisable, due to the rich soil found thereon. Lespedeza, red clover, prtridge peas, cowpeas, buckwheat and corn were planted in 19.7. Gane food trees and shrubs were planted on marginal lands. Ditches were cleaned. A nursery was constructed for propagation of native wild food producing shrubs, trees, vines and legumes. Since 1935 there has been a substantial increase in most species of wildife native to this section--bobwhite quail, rabbit, grey squirrel, mourning doves, woodcocks, raccoons, skunks; as yet no deer have been seen.

This area developed for increase of wilalife by providing food, cover, predator control, has showed increase in wildife. Developnent of other such areas should do much to increase and conserve wildife. This report should interest conservationists and legislators.

Wildife Review, United States Depertment of the Interior, Bureau of Biological Survey, Mashington; No. 20. February 1940. 54 p. mimeo.

Abstracts or books, magazine articles, leaflets, and government reports are given. All phases of wildiffe-control, diseases, food habits, life histories, management, etc.--are considered. This could be used by college students and research workers for sources of material. 
MTIERAL RESOURCES

The Storehouse of Civilization, Furnas, C. C.; Teachers College, Columbia University, New York. 1839. 551 p. illus. graphs.

uch of this book is a discussion of the utilization of natural resources, pointing out many of the problems that arise. The formation of mineral deposits (geological history), their aiscovery, recovery methods (mining, pumping, hand-picking, gravitational separations, flotation, chemical, etc.) and the usable ores and reserves are discussed. The reserves of metal mineral deposits of grades that are now considered workable are not now satisfactorily known. The records for iron and copper are fairly accurate. One great need of our mineral industries is for more scientific prospecting; improved techniques for handling lowerade ores would increase the size of the reserves enormously. Conservation of metals by use of scrap, more efficient utilization, substitutes, and combating corrosion would eliminate shortages for several generations. The supply of nonmetallic minerals (halogens) is fairly ample. however, efficient recovery methods, using new sources, and minimizing waste will prevent future concern. Our present fuel resources, particularly petroleum, are near depletion. Wuch coal is left in the ground because of faults of the ecomonic organization. Oil is left in the ground because we do not know how to get it out. Most of our power plants and heating rurnaces are inefficient. Oversized and inefficient engines use too much gas. Synthetic chemical industries are using more coal and oil as sources of materials. 
The scientist will devise new techniques (energy from the sun, new sources of raw material) to meet future needs if there is widespread public support and demand. And that calls up a task for education. A full discussion of social implications (to the individual and the group, mass production, working hours, leisure, etc.) is given. This volume describes the raw materials ith which man has to work and what he does with them. Suggestions are given as to how he can improve some of his processes. The sociological effect of many scientific and technological developments are pointed out.

This book will greatly enrich the background of the reader, and it will broaden his knowledge. It is not intended as a textbook, but the material could well be used in geology, sociology, economics, and geography courses at a college level.

United States Minerals and Us, Palmer, I. L. New York State College of Agriculture, Cornell Rural School Leaflet, Cornell University, Ithaca. Vol. 35. No. 4. March 1942. $32 \mathrm{p}$

In the present war, the outcome will greatly depend on whether he have enough war materials or can find substitutes. The leaflet describes the uses of minerals, their sources and New York's place in their production. (1) Jinerals and shelter (gypsum). New York ranks first of all the states in the production of gypsum. (2) Ninerals and containers (tin, aluminum, enamelware). (3) Minerals and protective coverings (lead paints, titanium, nylon, vinyon). (4) Minerals and machines of transportation (aluninum, 
beryllium, magnesium, helium, steel). (5) Minerals and tools (steel, cryolite, florspar, mamenese, nickel, chromium, tungsten, molybdenum, sirconium, rubber, quartz, copperi. (6) Minerals and fuel (coal, oil, gas, peat). New York has contributed largely to nation's fuel supply. (7) Minerals and explosives (mercury, glycerine, sirconium, antimony, sulphur, salt, nitrates). (8) Minerals and efficiency of machinery (greases, oils, graphite, emery). New York seconc in production of milstones; has important garnet resources. (9) Minerals and food (potassium, calcium, magnesium, iron, copper, phosphorus, chlorine, lodine). (10) Ininerals and control of enemies of plant foods (arsenic). New York school children can avoid waste of important minerals.

Witten for teachers, this leaflet may be of some use in a project dealing with sources of our essential war materials. 
IUUMAN RESOURCES

Doctor Preaches Conservation, Forman, Jonathan; reprinted from Ohio Conservation Bulletin, State Department of Education, Conservation Labratory, Columbus. Undated. 4 p. Excerpts from an address given before onio Congress of Parents and Teachers are given.

The quality of nutrition depends upon the quality of food and the guality of food depends primerily upon the soll on which is was raised.

The greatest single thing we can do for our country is to see that our people eat enough of the right kinds of food. The next greatest contribution is to join the movement for soil conservation. These two things vitally concern the health, welfare, and mental alertness of our pupils.

This address given before parents and teachers discusses the need for conserving our soils in order to maintain the health of our nation, and incidentally the vigor and continued existence of wildlife. How Man Satisfies Gis Need for Food, California State Department of Education, Curriculum Units for Elenentary Schools, Sacremento. Vol. .1, No. 4. September 1942. $176 \mathrm{p}$.

Today's education is related to current problems; conditions show that one-third of the nation is ill-fed; that a large part of araftees were rejected because of poor teeth; great numbers of Americans lack fruits and vegetables yet products of truck farms and orchards are wasted; that numbers of Americans do not have the means 
to purchase food necessary for a minimum healthful diet; and others do not know how to purchase wisely nor to prepare food scientifically.

This bulletin is presented in three parts: Part I treats man's quest for food from his early beginning to the present day--the influence of climate and soll, migrations and movements of people over the earth's surface, development of trade, commerce, cities and nations, scientific and mechenical inventions, relations of adequate food supplies to problems of war and peace, etc: Part 2 deals with basic considerations regarding nutrition--effect on the individual, signs of good health, functions of food in the body, selection and preparation of foods, sources of nutrients, etc.; Fart 3 is a composite account of activities carried out in this study--problems, activities, experiences in (I) study of t'arm and dairy life (primary level) (2) study of arriculture (intermediate level). Is source material for teachers the bulletin is excellent to enrich the background of understanding and to acquaint her with the problem. The units are suggestive and helpful. The bibliography tor teachers and pupils is full. Visual aids available to California teachers are listed.

utrition and Conservation, lennessee Valley Authority, Fealth and Safety Department, Chattanooga. Way 21, 1942. 5 p. mimeo.

Land and the theory and practice of nutrition are inseparable. Man's food is derived from the land, hence the conservation of the $l$ and is of vital significance. 
Yet the land is slippine away and with it go vital elements. The supply of some of these elements is inexhaustible, but some are not, and without them the inexhaustible elements are useless to us. All of the elements are important, but to the nutritionist the conservation of phosphorus, calcium and magnesium are of most coneern.

Qefore man began to exploit the soil neture maintained a cycle whereby the elements mere restored to the soil. fan broke that cycle.

Nature has made an uneven aistribution of the soil's minerals (examples in Tennessee are cited). Mineral deficiencies in the soil are reflected in deficiencies in the crops grown and in the cattle feeding on the crops, which ultimately has a direct bearing on man's nutritional problems. Research showing direct connection between soil deficiency and deficiency in the human organizm is still in 1ts early stages. However, it has begun "goiter belt" in the United states where there is an iodine deficiency in the soil in that area).

A nutritionist's responsibility extends far beyond the problem of aily food requirements.

on a high school level, this article could be used in nutrition or conservation courses to sho: the direct relationship between health and soil conservation.

Bich van, Foor Man, Goslin, R. A. and Goslin, O. F. Harper \& Bros., New York. 1965. 85 p. illus.

The country in wich we live is the richest country in the world, not only in terms of dollars and cents, but in all of those things that are necessary for the making 
of dollars and cents. Using 1929 as the basic year, the authors show how our economic system has broken down. "We heve an abundance of natural resources and the facilities for converting these into usable form. Yet as individuals, our people do not all have enough food, clothes, houses, or medical care. They do not have the income, or enough jobs to purchase these goods.

As a nation, we are rich--as individuals poor. All of us depend upon other people having money and the desire to buy what we have to sell. There are certain reasons why exchange of goods and services are impossible--fewer jobs, low wages, debt, limited supply, war, depression, etc.

In order to use our wealth advantageously we need to distribute goods as a service rather than for a profit. The government should be the agency to take charge of those fielas of activity which are essential in providing the necessities of life. Social omership is neaded in providing (1) an unvarying medium of exchange, (2) control of credit, (3) conserving natural resources, (4) ownership of power, (5) production of goods, (6) transportacion of of roods, and (7) distribution of goods.

This book is simply and non-technically witten. The Eraphic illustrations tell a clear, understandable story. scientifically, it is shown that government ownership of certain phases of our economic system would assure to all of our people enough food, shelter, etc. for the good things in life. Fowever, the American way is not in accord with social ownership, and the advisability of oreanization 
and functioning of such a system is questionable.

This publication could be used as a text in economics at a senior high school level. 


\section{MISCELLANEOUS}

\section{A Stuay in Conservation, Minneapolis Fublic Schools,} Minneapolis, Minnesota. 1940. $836 \mathrm{p}$.

This bulletin gives a Eeneral overview of the work done in conservetion in Minneapolis Public schools. Chiliren's experiences, reports, illustrative material, and teacher's accounts are given. The topics covered are soil erosion ana depletion, water conservation, forest preservation, minerel resources, and wildife protection.

As one reads the reports and experiences witten by chilaren from kindergarten through the sixth grade, one has the feeling that they have learned much in certain fielas of conservation. The accounts show how varied and extensive were their interests. Their excursions, collections, building, search for information through writing of letters, ano. other activities were rich and meaningluI. The interation of conservation and history, geography, English, mathemetics, and art is easily iaentified. Wuch uee was made of communty and state interest and inf ormetion.

Of value to teachers contemplating teaching of elmost any field of conservation on an elenentary school level, this bulletin gives excellent ideas and suggestions as to what can be done. With each topic is a very full and complete bibliography of books, magazines, phamplets, government materials, and encyclopedias which were used with success by teachers in carrying out this study.

A Tentative, Suggestive Special Unit on Washington History and Government, Vashington Department of Fublic Instruction, 
Olympia. September 1941. $7 \mathrm{p}$.

In this unit, on junior hish shool lovol, the outline consicers the problem of man adusting himself to the natural environment and adapting its resources to his needs--in the Stone Age, the Indians, in the river velleys of the ivile, Tigris and Euphrates, and in United States and Vashington state. Particular emphasis is on soil, plants and animals. To be used in a world history class, the content outIine is well oreanized, but no suggestive activities or proceaures are eiven; the biblioraphy is very meager.

Abstrects of Bulletins No. 581-595, Circulars No. 80-90, and Other Publications During 1940, Jackson, A. A.; Agricultural and Mechanical College of Mexas. July 1941. 51 p.

The abstracts given are those avallable from the Pexas Agricultural Experiment station and cover aninal production (aiseases, food, beef ana dairy cattle, poultry, sine, sheep, goats), epiculture, fertilizers and soil, field crops (cotton, corn, sorghum, grasses, small crain, legumes, pesture crops), horticultural crops lfruits, native plants, poisonous plants, vegetables/, and home econmics. Most of the articles are technical and of interest primarily to the specialist.

Aids to the Stuaent of Conservation, Visher, Stephen; John Wiley $a$ Sons, Inc. New York City. 1957. S2 p.

Mis publication is aesigned to be used in connection with the book, Our Naturel Resources and Their Conservation, by A. E. Parkins and J.R. Mhitaker. On each chapter is a set of questions. One group is review work on the chapter 
and the answers can readily be found in the text material. Another group consists of thought-provoking questions. These are excellent and aid greatly in applying facts to presentday situations. They could well be used as guides for discussion.

This is an aid usable by both student and instructor.

America's Capacity to Produce, Nourse, Edwin G. \& Associates, The Brookings Institute, Washington. 1964. pp. 1-157.

This is the first of four volumes in which the authors plan to establish the trend of capital expansion in the United States for the period 1900-1930, and to estimate the capacity of the industrial plants built and whether or not these plants are utilized to their full potentalities. This first volune is concerned with raw materials, fabrications, and services.

Under the heading raw naterials is included (I) agriculture--the conclusion being that considerable investments in the form of builaings, fences, wells, etc. have become unproductive, and that wile there is no demonstrable trend toward power utilization of the farmer's capital plant, its ratio of use in absolute terms is low; (a) mines--(a) coal --production has not reached capacity, (b) coke--much obsolete machinery, but efficient equipment working close to capacity, (c) petroleum--production, refining, and storage are not paralleled and have failed to utilize their full capacity, (d) copper and other nonferrous metals--copper--percentage of utilization about $80 \%$ of rated capacity, zinc--below capacity, aluminuin--output close to capacity. The output of the metals was expanded by the war and underment a post-war adjustment, 
and after 1923 the ratio of capacity to demand improved. Cement and other earth materials experienced rapid growth from 1989-1913 and culminated in a large excess of cepacity, a period of stationary developnent during the vorld Wer, and again a surplus of capacity mas apparent in 1929 . This study of our raw materiels is important in conservation because it indicates how much more rapidy our resources mey be utilized, and brings us to the fact that wise use planning, Hithout waste, is necessary and mill be increasingly important. Production in practically all phases increased to near capacity during forld War 1 , and now that our country is in the throes of world $19 \mathrm{r} 2$, we can be sure that even more resources are being used. This book mould be most useful for college students in a study of tochnologic or industrial economics.

Mmerice's Natural Nealth, Lieber, Richerd; Iarper a Bros. New York City. 1942. 840 p. illus.

This straight-forward account of Anerica's resources, their use and abuse, is presented by a man whose entire Iife has been spent in the field of conservation. America as a nation has been singularly fortunate. Natural wealth is the source of our prosperity and the basis of our national intitutions. Unfortunately, we have carried on a terrific weste in nearly every direction. Few recosnize the presence and influence of minercls thouch they are the lite-blood of our entire power age economy. Porests, lakes, streams, mountans, and fertile valleys are all integrated. The corplex and highly integrated problems of eneral land use are closely releted to private onership, prevalence of farm 
tenancy and share cropings. The problems of floods, droughts, erosion, reclamation of subnarginal lanas and irrigation are too laree and veried to be met by the individual or the state. Cur parks (national anō state) have been established to preserve exumples of natural wonders and wildernesses. Ereservation should take precedence over use, yet all perks should be self-supporting. The history of the conservation movenent is traced, and the work achieved by each event--o.c.c., Soil Conservetion Service, Sureau of Reclanation, Nationel Resources Flanning Board, etc. e as a nation he had a rather haphazarà appoach to conservation, yet vieved in its totality, there appears a seneral trend in the direction of needed national action.

Throughout the material the author shows the great need Por a unified approach to problems concerning the consorvation of our natural resources. For effective, intellicent, and comprehonsive action, all coneervation natters should belone in one epertment. The attitude of the public and the lewnek moula be strenethened, and existing disoranization in Federal Conservation would be freed of overlapping and conflicting jurisactions, bureaucratic jealousies, waste, and ineficiency in the present chaotic arranement.

ritten for the layman as well as college students, this account gives us much for thought. The piece-meal approaches and activities in conservation are clearly shown; a netional policy is grestiy and urently needed. Written in en interestine style, the book has much educational value for all adults. The appendix of chronology of events affecting conservation from 1020-1042 should be helpful to many students. 
Americen Democracy Anew, Odum, H. W., Meyer, H. D., Folden, B. S., Alexander, F. W. Henry Holt and Company, New York City, 1940. 600 p. illus.

This book is a study of the nation as a whole. uithin the frame-mork of the American picture, the problems studied are the physical and cultural backsround, the people, the institutions, and the testing rounds of the people (weleare, technology, planning, etc.). Then too, a picture is given of the south in its ricaness and variety, and its place in the total nation. Throughout the stuay emphesis is placed on the natural wealth and its affect on the nation. The existence, development, distribution and use of natural resources condition the nature and the quality of civilization and culture. In America, in recent years, the conservation, development, and use of natural resources have becone new themes for education and governinent, and for economic and cultural enrichment. There are in reality two great sources of societal wealth: the people and nature. The ereatest benefit and utilization of each depends upon the other. Changes in the American scene have been brought about by science, technology, and natural eorephic environment. The six najor rezions or the United states present difeerent views of life. The critical problen of technical ways of guaranteeing a genuine balance of velfare and wealth throughout the nation is one that we must meet. In the repional study of the south, the main point brought out is the superabunlance of netural and human wealth, and the lag in the neasure of its technological wealth, artificial wealth, and its institutional moajes of life and culture. 
The trend in this lag is definitely porward at the present.

This inventory of the American scene stresses over and over the basic importance of our resources to every aspect of Americen life. The problems of American democrecy are presented and interpreted in reletion to the historical backround, and to the realities of our resources and our regions.

At high school level, as a text for social stuaies, and as supplanentary thaterial for economics, geosraphy, or conservation courses, it contains much rich material. The questions for discussions, the problems set up and the bibliography are very good.

Anerican liature Association quarterly Bulletin, Anerican Neture Association, Nashington; Vol. 1, No. 1. April 1938. $50 \mathrm{p}$

Some of the fundamental conservation problems confronting the United States are (I) administrative--The Game and Fish Commission and the other agencies administering wildife resources are greatly involved in politics; revenue largely from sportsmen; (2) waterfowl--law protection not enough; (s) predators--no prosan should be undertaken without scientific knowledge; (4) refuges--no hunting or trapping allowed; (5) poison and traps--every possible precaution should be exercised; $(6)$ soil--gragt need for a more scientific and practical attituae; (7) National Parks and Forests--extension of road facilities, recreation, lumbering, etc. should be Iimited; (8) bollution--control by Federal Government; (9) roadside commerce--regulated by zoning; (10) Federal Bureau Reorganizetion--transfer of Grazing Division to the Departient 
of Agriculture, and merged with Grazing Division of United States Forest Service; Civil Service throughout bureaus.

This is the first number of the quarterly Bulletin and is devoted to a discussion of the ceneral problems of conservation and the attitude of the Association with respect to them. The proposals given ara sound and constructive. This magazine is interesting to any individual or group sincerely and unselfishly interested in the future of our natural resources.

American Rezionalism, Odum, I. W. Hoore, H. T.; Henry Holt \& Co. New York City. 1938. 641 p. illus. Regionalism is a term used in a variety of ways and with many meanings. One must interpret the meaning in relation to the relatively specific usage. As used in this volune, regionalism means the societal region combining a relatively large degree of homogeneity measured by a fairly large number of indices available for a relatively large number of purposes or clessifications. This definition implies a unifying function. It is a tool and a technique for various objectives for planning, for decentralization and aistribution, as these relate to population, wealth, and sovereignty. The natural regions of the United states are considered as six areas. The indices used are: clinate; mining and industrial regions on bases of coal, iron, petroleum and other minerals; in terms of characteristics of the soil (many subdivisions); regions of natural vegetation; river valleys, , and many others. In the I.V.A. may be found all the elemental factors of American regionalism. Cultural regions are con- 
cerned with other indices. Various historical and cultural aspects of regionalism are those of the geographer, the anthropologist, the ecologist, the political scientist, the economist, and the sociologist.

The six regions and flexible sub-regions presented in a general outline framework are: (1) The widale states ana Their "Fidale Vest" are the heart of the nation's bigness and complexity (an agricultural-industrial eroup); (2) The Northeast and Its New Ingland--people, financial resources, national manufacturing, centers of art, literature, and arana; (3) The Southeast and Its "Old South"--the most American" in range ana abundance of flora and fauna, land and forests, its tempo and pattern of ruthless exploitation of resources, both natural and human; this region is nearly al ays in the lowest quartile of the 48 states by all indices; (4) The Far Fest and Its California--great "unity in diversity"; (5) The Northwest and Its Great Plains--en inland rural region, manufacturing and industry conspicious by their absence; has the problem of mastery of physical environment (Iand and water); (6) The Southwest and Its Texas--"least American" of all the regions, youngest historically, its ultimate wealth unpredictable because of the many possible developments. These divisions illustrate the theoretical and historical aspects and practical implications of regionalism.

This volume is a picture of contemporary regionalism in the United states. It is an inventory which serves as a basis for planning in the ligit of realistic situations. The reions are vieweu $a s$ a wole and also as constituent parts 
of the national unity.

The maps and charts supplement the printed page. The bibliography is very complete and up-to-date. This raterial is well written but could be used only by advanced students of sociology, Eeography, or history since an extensive background is necessary for understanding and application.

Arkansas: Natural Resources, University of Arkansas, Hayettevilie. 1942. 451 p. illus.

The various state and nationel conservation asencies have done much to secure the oroper use and development of the natural resources of the state. Wvery citizen must assume a sense of responsibility for cerrying out the conservation code. This responsibility requires some knowledee of the problens and their suggested solutions. come of the important problems are (1) expsion--one-sixth of the cultivatea crop land has been severely damaged; (2) minerals --oil, natural gas, coal, buxite, zinc, and others are being exhausted at a ropid rate; (b) flood damage is increasing; (4) forest products are second in value of the state's resources, and less than six percent of the forest area is now in virgin or old erowth timber; (B) plant life--Arkansas has over 2,600 varieties and species of plants, and little tlought is being given to their protection except in recreational areas; (0) wild animal life--there have been tremendous decreases in the wilu animel population, and in some instances, the loss of the species. Bach of these problens is oiscussed in atail and suggestions as to how to work out conservetion programs for each resource are iven through protection, elinination of waste through extractirg, replenishing, economical use, 
ario substitution, or reclemation.

In 1039 the Arkansas Lejislature enacted a law requiring the teaching of nature study and conservation in 11 public schools. In order to make available facts and suggestions on the state's resources, this bulletin was written. It is excellent source material and very complete. The biblioeraphy is very sood. Incluad in the appenaixes are conservation laws and statistical date for the state. The bulletir stresses distribution, conservation, and wise use. Erimarily for the use of those preparing courses of study, it contains autroritative ireormation for all persons interested in promoting public velfare in Arkansas by means of the proper care and use of the state's natural resources.

California's Naturel Wealth, (A Conservation Guide for Seconary Sohoolel. Bulletin of the California state Depertment of Education. Vol. 9, No. 4. (Decenber 1940 ). Sacramento. 124 p. illus.

To meke adequate and comprehersive plans for the use, development, and enjoyment of its natural resources, an understanding of Californis's geosraphy is needed. The land forms, rivers, lakes, etc. are discussed. In planning to prevent waste, conservation must (1) be integrated, ( 2 ) include stuay of land use, (3) correlate lana use with water development, and (4) be in cooperation with all groups and aeencies.

of all resources, water stands first in the estimation of most CaIifornie people. The rainfall distribution, undereround waters, floods and flood control, and run-off are discussed. 
With the repia settlement and increasing demand for more food, more land has been cultivated and protective vegetation lacely removed. Agencies actively interested in public education in the field of conservation and applicstion of conservation measures are the Acricultural Extension Service of the University of California and the Boil Conservation service.

The flore of the state includes forest, desert, frassland, chaparral, sogebush and woolend plants. The primry objectives of conservation should be to prevent deterioration and hasten the natural process of restoration. Froblems of forest management are discussed. The recreational and scenic resources have received increased reconition as a valuable asset of the state.

California has a wealth of mineral resources. Nethods are recommended for their conservation through production, manufacture, and substitutions.

Conservation in the curriculum should be meaningful and not confined to written work. Surveys, interviews, experiments, excursions, books, visual aids, eto. should be techriques used in a study of resource problems.

his bulletin contains a wealth of meterial for the teacher and sugestions for integrating conservation rith courses in natural science, social studies, inlish, methematics, art anà home economics. It contains excellent references (books, bulletins, phemplets, magazines, maps) on each topic aiscussed.

Por use in secondary schools, it is good source material ior the teacher. 
Choose a Book About Things to be Conserved, Mackintosh, Velen K. and Bgthurst, Spife G.; United States ofice of Iducation, Government Frinting Office, Nashington. 1941. $19 \mathrm{p}$.

This is an onnotated list of books (for children) on mamals, frogs, snakes, fishes, trees and forests, birds, soil anci water, minerals, wild flowers and plants, and insects. The reading level for each book is given. The descriptions are interesting and should helo librarian, perent or teacher in selecting books ior children. Conference on Caucation in Conservation, Netional vildife Federation, Washington. February 1959. 69 p. illus. This conference, held in Detroit, wos called for the purpose of finding out how cons rvetion could ba waras through education. Various papers presented activities in several states. T. B. Benner spoke on sone of the conflicting points of view which needed to be hernonized. He favorea correlation of conservation and other subjecos, not a separate course or subject of conservation; educational leadership through the United States Department of Lducation, American Council on Education, N. B.A., Frogressive Bducational Association, and others; not bring conservation into the schools through securing laws requiring its teaching, but through the mediation of competent leadership; contact leading publishors of textbooks eor knowledse of textbook possibilities; the problem of training of teachers, and the builzing of bibliosraphies.

Indina's conservation program of organization of conservation clubs, throughout the state was described. renne- 
ssee's program consisted of meeting with teachers' groups in curriculum conferences, curriculum builing, traveling exhibits on birds, animals, forestry products, land erosion chapts and supplying teachers ith materiels on conservation.

Cornell's lonetime program of issuing their Leaflet on related material for conservation study is described. At Zanesville, Onio, using the ruskingum conservancy District as a labratory, teachers are trained, films shown, experiments carried on, and conservation is the "core" subject.

In isconsin, selection of teachers with ability and desire to do something for conservation, supplying materials por use, and integrating conservation throughout ali levels, is the proeren.

The National Wildife Federation has a three point plan for conservation eaucation--(1) statenent of fundanentals, (a)eroups to be approached, (3) development of educational setiods.

This is an excellent example of educators getting together and exchaneing ideas, and en organized group taking their share in the work. For ell educators, teachers, and administrative officers, this is interesting and vorthile reading.

Conservation, The American Forestry Association, Vashington. This magazine, published every tio months, is a digest of current articles on the conservation of natural resources. The articles include all phases of conservation. The cost is $20 \%$ a copy or $\$ 1.00$ a year.

This magazine reflects the trends in conservation and 
the research being carried on. The magazine is usully 50 pages, so not all the conservation news can be included; honever, it gives a fairly good picture of conservation, since aigests are made from a great number of sources. The articles are non-technical and should interest the layman anà adult student.

Conservation, Builaine Anerica Vol. 2, No. 7. Americana Corporation, New York City. 1937. 31 p. illus.

America has great natural resources--fertile soil, dense forests, adequate rainfall, and rich mineral deposits. A large part of the land has been destroyed by the plow and axe. As a result fams and grazing lands have washed dom to the sea. Cattlemen and sheopmen made large profits but too many cattle and sheep destroyed the short grasses in large areas. During orld "ar 1 the orla called for more wheat. Vestern farmers plowed up thousands more acres of prairie lands. Heavy injs and dry years resulted in the Dust Bowl. To save our soil me can (I) halt water erosion, (2) prevent wina erosion, (3) stop loss of minerals, and (4) prevent overgrazin. The soil Conservation Service is working on all four phases. The United states government is preserving forests by (I) setting aside areas, (2) potecting from fire, diseases, etc, (3) reforesting, anà (4) leasing land for grazing and timber cutting. steps are also being taken to preserve our minerals.

This pictorial stuay unit aiscusses (1) what has caused nsete, (a) wat Anerican people are doing to halt the waste, (3) what the government is doing. Phis is a vel: or anized unit written for school use 
and the general public. Parts coula be read by sixth eraders. It zives a clear picture of the problems, it causes, and ways of solving the situation. The pictures are good and aid in interests and explanation.

Conservetion, Cornell aural School Leaflet, Wew York State College of Asriculture, Cornell university, Ithaca. Vol 29 , No. 3. January 1936. 20 p. illus.

Ideals of conservation should be broadened to include not only interests in the strears, the rocks, and the living wild things, but interest in man himself. Problens asoociated with man's health, wealth, safety, and eeneral prosperity, both as an individual and as a member of a community, belong in the field of conservation.

The activities included in this learlet are concerned with (1) wildife--providing shelter and food for birds, visit sanctueries, investisate fur-bearers in New rork, discuss use of steel traps, make casts of tracks of biras and aninals, locate bird's nests, recora number and kinas of snakes you fina, etc.; (2) soil and vater-notice effects of heavy rains on your yard or school grounds, collect samples of earth for experiments, make trips to note how watermays are usea, etc.; (3) Jodlana--observe destruction causea by fire and disease, observe cut trees for rings, note values of wood, study wildplowers in your vicinity, etc.; (4) general activities-buila a library (biblioraphy given), take excursions, make meps, carry out experiments, etc.

The suggestions in this leaflet are primarily for teacher supervision. Thach use is made of the community. It should be very helpful. 
Conservation, wurphy, Robert C.; Bulletin of the Garden Club of America; January 1938, pp. 39-50, March 1958, pp. 36-36.

The conservation movement is the public reaction to abuse of natural rescurces. Thus far it is larely in the negative staee of protest. In primitive lorth America we had what naturalists call balanced nature. Destiny decreed the building of a nev civilization. Some perts of our country have been damased more than others. In Virainia the loss of mildife, including flowers, birds, fish, fur-bearers and tame, has been largely unnecessary. The forests are fundamental; they are necessary for the holding of cround ater, protection against erosion, and home for wildife. Overgrazing and erosion are two evils from which Virginia has suffered less than her near neighbors, yet we easily see the effects of erosion in Virginia streams if less easily on the land.

The importance of all insects and mammels now classified as "vernin" is discussed.

Conservation is a broad and intricete subject. The time for uess-mork has passed. One of the nost encouraging signs of today is the srowing illingness of the public to recognize the validity of informetion deived from the researches of naturalists.

This article points out the needs of Virsinia, the interrelationships of nature, and the necessity for understanding conservation principles on the part of the public. Given before an interested group of Geraen club rembers and the Izagk alton League, it helps clarify the situation somewhat. 
Conservetion, Murphy, Robert C., Bulletin of the Garden Club of America. Nay 1940. p. $40-49$.

The natural riches of Morth Alerica ae in a far more critical state than as even been genersily realized despite widespread publicity during the past few years. Whether we consiaer forest products or fisheries, the story is a sinilar one of eppallingly depleted supplies. The shortages are pertIy rasked by the facilities of modern transportetion. Froper land use and vildife conservation are interdependent, and to some extent, interchangeable terns. The things they stand for form a fundamental basis of our national economic Iife, and the latter can hardy be separsted from our cultural Iife.

It is curious that the press bas never caugh up ith tre lnortance ara publicity value of this great socioeconomic need. The space given to "rod and gun" is in sharp and unfortunate contrast to the attention paid to conservation. The history of conservation is largely a record of interaenominational squabbles. Uniformity of purpose needs to be developed.

our national point of view seens to be one of delusion-that this nation abounds in wild territory and a 11 the things that go with it. Te need to arive home the point that many of the "things people have always known" are none the less false.

In this address the education of the general public is stressed--that our riches are being depleted, and avare of this, the public pill act. The article would be of interest to those who are concerned with conservation. 
Conservation and Citizenshin, Renner, G. T. and Hartley, H. D. C. Heath \& Company, Boston. 1940307 p. illus. "Conservation is the preservation of our natural resources for economical use, so as to secure the greatest good to the largest number for the longest time." It is no longer a small matter. It is rapialy deepening and iaening stream of forces in our national life. Most of our resources have been widely misused; despite enomous vaste, America has becone a strong, Iarge, and wealthy nation. Wut the ase of abundance is over; we are now entering an age of readjustment and conservetion. Very complete aiscussions of our forest, soil, water, wildlife, mineral, and human resources are given. These are dealt with as to the extent of the nsture and importance of each resource, how the resource has been used and the extent of misuse, and the steps which might be taken to remedy the damage an to prevent further waste. Accompanying each unit or chapter are questions, suggestive topics for reports, noteboor projects, cartoons, drawings, fleld trips, etc. The appendixes give sources for motion pictures and suplementary reading. The pictures in the book teli a vivid story. this book, intended as a text for junior and senior his students, is written in a simple and readable style. The material is vell orsanized. Socisl and economic irplications are stressed; wise use and plannine on the part of American citizens is necessary, and is well token care of in this book. Is a tewt for use in conservation or eeoerephy courses, it is excel ent; as supplenentary reacing for civics or economicsit is well suited. 
Conservation and Defense, Dage, Rosalie; Emercency Conservation Comittee, New York City. 1941. (Report for 1940). Fub. No. 84. II p.

The E.C.C. urges for the Forcupine Mountain area a plan to give the Forest Service the management of the part of the forset thet is desirable for comercial forestry; and that portion of the area which should be preserved be made into a national park. The a.c.c. supports bills which provide for pure streams. The a.c. continues to support regulations for increase of waterfowl. Win the National Auabon society, the sola for millinery.

Publicetions of the I.C.C. In 1.40 were two new units on vateriowl and hawks. Anotrer on preatotors is roady for publication.

In 1940-41 the I.C.C. Oened an intensive campaien to aave the Irumpeter bran. A lecturer was sent to Idaho and yoming. Fe had traveled more then 2,600 miles.

This sumary of the Committee's activities is varied in scope and interestingly presented. It serves to keep the public informed and indicates the trend of events in certain phases of conservation work.

Conservation and Vature sducation, Vilaes, F. A. Vinnesota Academy of science, University of Minnesota, imeapolis. April 15, 1955. pp. 25-31.

The ereater portion of Hinnesota's adult citizens have an imperfect or unaeveloped izea of what constitutes conservation. This lack is due to the fact that whlle young they were not led to understand the full value of things 
about them. The work of a comprehensive conservation proeram demands the attention of schols and colleges. Nature study had a prominent place in the schools forty years ago. It was discontinued in some schools, probebly because of lack of training of teachers. Its revival is of utmost imfortance if we are to fully realize the continuing velue of nature's gifts. Pan has shorter woring hours and more leisure. te should sense the importance of conserving our resources for recreational purposes as well as for economic reasons. The full importance of all phases of conservation rust be instilled into tre minds of the young wuring the fomative period of their lives, so that when they bacome adults the lessons of yuth will become a prt of their noke-up.

This article stresses the value of education as a part of the consorvation prorem. Discussed in non-scientiIic terris are the needs of conservation and the pert education can and must take. Iritten for the average reader, it relates eaucation ana conervation.

Conservation and the Kentucky Teacher, Gilpin, James J. Kentucky Conservation Department, Frankiort. Unated. I9 p. nimeo.

During the early years of a child's life is the time to begin to develop the principles of conservetion. In the lower grades the objective of such work is to give the child opportunity to establish rentel attitudes tovard conservation. Attitudes so formed will definitely direct his interest and bensvior ir leter life. Some enotional factor shoula 
be introduced if that teaching is to become an integral part of the child's thinking. Sentimentalism should be avoided but friendship, trrill of discovery and pride of possession are emotions wich are wholesone, and do not offend the intellig nce of either adults or chilaren. Establishing friendy relations between chilaren and other living things is the most important mork in the lower grades.

In the junior hich school years children are more concernea with their own outaoor sports--hikine, huntine, ishing, trapping. Concepts of subjective values should not be stressed too strongly.

At the senior hich school level boys and irls are learning to think subjectively. They raxidly become the chenpions of "lost causes," and if guided, one of the great opportunities is to direct this crusedine spirit into the movement for the protection of our vildiffe and the wise use of our natural wealth.

The suggested activities for use in conservation studies are varied--excursions, exhibits, home projects, etc.

The phamplet gives a good overview of conservation principles and what the teacher can expect and on what to place emphasis.

Conservation Bibliography for Visconsin Schools, Hisconsin Department of Fublic Instruction, Radison. February 15, 1941. 7 p. mineo.

This is a list of books (ennotatea) about conservation in Eeneral, material available fron the isconsin conservation Department, the state Agricultural Departinent, and magazines helpful in a conservetion program. All the material 
listed is on a junior or senior high school level.

The Iist is not lons, but the material is up-to-jate and very relieble. It should be helpful to teachers in Gathering material for a conservation program.

Conservation Bulletin for Use in Schools of Nev Hampshire, Garden Clubs of Anerica (and affiliated clubs). New York City. 1941. $40 \mathrm{p}$.

phis bulletin is compiled of articles written by various people (fudubon society, Nev Hampshire Conservation Department staff, United States Department of Agriculture, etc.) who are either vitally interestea in conservation or are experts in their field. The articles are rather broad in their scope--the topics being conservation education, wild flowers, biras, insects, ish and came, trees and forests, soil, and mater. These might be of help to the teacher. The strong point of the bulletin is the bibliography which includes factual meterials, story and picture tooks ana phamplets and magazines. Some of the books indicate the aee or grade level. This list would be of great aid in gathering source material.

Conservation by the Feople, Eage, Rosalie, (Annual Report fr 1941), Mmereency Conservation Committee, New York City. 1942. Fub. No. $85.13 \mathrm{p}$.

The activities carried out in 1941 by the $\mathbf{2}$. C.C. included (1) protested aeainst the planned army camp ana artillery rance at Henry Lake, Fontena because it was the flyay of the few remainine Trumpeter owans (successful); (2) engaged Geor e arler to lecture in Idaho on the Trumpeter Svan; 
(3) protested the use of poison by Fish and Wildife Service; (4) protested Senate Bill 1476 which would permit slaughter of deer in Florida because deer harbor a tick which carries cattle fever; (5) worked to save Cook Forest in Eennsylvania; (E) campeigned against proposed ski-trails and toms on hiteface Mountain in lYew Tork; (7) opnosed amenament to plumage law in New Tork; (e) worked to accomplish closed scason on waterfowl.

This Comittee is primerily concerned with legislation regering conservetion of wildifie and forests. It seems aware of the problems and actions throughout the country, and takes steps to keep the public informed and urges them to protest aeainst detrimental messures.

Conservetion--Come and Get It: Dage, Rosalie, Emerency Conservation Comittee (Feport for 1959), Nev rork City. Warch 1089. 24 p. illus.

After much campaigning, the olympic Netional rark mas established. Hawk Mountain Sanctuary is now estabiished, independentIy of the A.C.C. An organization of sportsuen, Ducks Unlimited, purposes to save wildforl by imroving the marshes of Canada and thus the waterforl of North Mmerica. The author says this is for general knowledge; to gunners, this organization promised longer open seasons, larger bag linits, repeal of some regulations. The E.C.C. plans to fight any action taken by this group. The is.c.c. urges building fish-Iadaers on the crand Coulee Dan to save decroasing salmon in the Columia Fiver. The E.C.C. issued six publications in the interest of conservation during 1858. This bulletin informs the public of some of the problems 
of our nation, wat this group is aoins, and urges all citizens to do their part by mitine the proper authority and by contributing funcs to the . C.C.

Conservation dacetion, prepared by the Pederal iriters Eroject, I.A.A. State Depertment of Fublic Instruction, Tarrisburg, Fennsylvania. Bulletin 214. Ly 1989. 108 p. illus.

$$
\text { One-tuelfth of Pennsylvanie's poople live on farms }
$$
Which cover more then half the state. where is reletively Iittle good land. Erosion is coused by water. Control measures are under the state Asricultural Depertment, the State soil Conservation Board, and the Depertment of Forests and aters.

Plood control is ingortant because floods are frecuent. The state ater nd Iovers gesources Board is chareed with pertinent date (surveys, hyaraulic works, etc.). The Fiealth Department maintains constant supervision of water supplies and sewage.

Forests are necessery to control erosion, maintain weter lovels, control floods, etc. To hande forests properly and give assistance, the Department of Forests and aters is active.

The state, because of conservation and restocking prosrams, has an abunance of wililife. The stete has rine fish hatcholo, 1 ane refuges, 41 cooperative farm eme projects, and four eame iarms.

The state leads all others in nineral production. Coal, cement, natural gas and petroleum are the main resources. New devices and methods of production help avoid waste. 
The state has taken steps in the conservation of human resources through health education, crime control, safety legisletion, and social service. A description of the tuberculosis prosam, prewmonia promam, social security, etc. are given.

The bistoric sites, perks, caverns, and scenic spots of haduty throun the state are listed.

This bulletin for teachers is excellent source material; at the end of each chapter are lists of classroom approaches. These are usially aiscussions or mitten reports. I feel that there shoula be more variety in these. The iilms ana film strips for each subject are excellent. The bibliography is adeluate but its use by elementary school children is questionale.

Conservation Excursions, Bathurst, iffie G. United states Ofice of Aducation, Government printine, office, hashington. Bulletin 1io. 13, 1939. 1840. $106 \mathrm{p}$.

Bxcursions are especially useful in a stuay of conservation because natural resources in the form of birds, trees, forests, etc. wich compromise the subject matter to be taugh cannot be brought into the schoolroom in their natural stste. The value of an excursion is to give the pupils a ractical acguantance with conservation as a problem which is basic to their own and the community's welfare, and a working knowlede to help them participate in its solution. The purposes of excursions vary. Some are taken for pure pleasure and result in appreciation of the outdoors and its benefits. Some result in aded knowledge. Other trips are taken to acuire knowledge not available in the classroom 
or home. Sometimes trips are taken to find materials for experiments. Conservation activities often require excursions for their consummation. Some trips are taken to interview experts in different fields.

The profits and pleasures gained are in proportion to the teacher's planning. Frelininary visits, reading and study, consideration of desirable results, transportation and equipment are a part of teacher planning.

follow-up activities may include records such as diaries, journals; letters of thanks and expressions of appreciation; displays and exhibits; school or class newspapers; map-making; moaels in sand-table, etc.

In the appendix is a list of suggestions on (1) where to go and what to see, (2) what to do, (3) further activities in a study of soil, water, flowers, trees and forests, birds, ish, minerals, history and culture. The bibliography is sood.

This bulletin is excellent for any teacher who plans teking her class on an excursion. It covers every aspect, and gives valuable, workable suggestions. This is especially valuable to beginning teachers.

Conservation Films in Elementary schools, Bethurst, iffie G. United states Office of Education, Government Frinting office, washington. 1941. 38 p. (Bulletin 1941, No. 4)

rotion pictures are a vivid aid in understanding how the Nation's naturel and human resources have been wasted and now the remaining supply can be conserved. Filns aupted to teaching conservetion in the elementary school are not lacking in number or quality. films should be selected carefully 
and the viewing group should have adequate preparation to insure understanding and appreciation. Standards in the selsction of films incluae (I) content in relation to the curriculum, (2) suitability for the grade, (3) contribution to educative objectives set up for the unit of instruction, and (4) technical eloments in relation to protosraphy, continuity, titles, etc.

Both teacher and chilaren need careful preparation if they are to profit by the use of films. The teacher should preview the film and organize her procedure by planning ways of using this material in learning situetions before and after the shoving. The chilaren should be prepared by reviewing facts and experiences already gained, suggesting items to be particularly noted, by assigned oral and written reports to be gainod from material in the film. Foliow-up activities nay be in the rorm of discussions, experiments, summaries, reports, carà-files, etc.

The annotated list of films on conservation gives source or film content, educational objectives, grade level, treatmat of material, background aesirable, and follow-up proceaures.

This phamplet is designed to help schools teach conservation more effectively through the technique of using moving pictures in the class room. To the teacher, comitte, director in charge of visual education, or the individual who desires to use films in relation to conservation studies, it vould be of great benefit since it suggests standards for the selection of films, and ways of applyine them in good classroom practices. 
Conservation for Victory, (Annual Report), Edge, Rosalie, Tmergency Conservation Comittee, New York City. Fub. No. 88. $1942.26 \mathrm{p}$.

The activities of the .... in 1942 covered the follon-

ing: (I) published three free phamplets; (3) contacted editors of newspapers and macazines on current conservation issues; (3) worked out campaigns for saving south Calaveras Grove, in California, to save sitka spruce on olympic Feninsuia; (4) save publicity to cuttine of timber on Forcupine vountains on shores of Lake superior in vichigan and urging that it be brought under the control of National Fark Service; (5) protested against building of a dam on Clarion River which borders Cook Porest in Pennsylvania; (o) worked toward establishing of Jackson Fole National Monument; (7) sponsored a lecture tour in Montana end Idaho for protection of Irumpeter Swan; (8) protested against Cestruction of the Bald Jagle and Duck Hawk.

This report eives the prosram and workings of this Comnittee for 1952. Wuch of the effort was on educeting the public through lectures and leaflets; the commitee is also active in legislative matters concerning conservation phases. Whis is one $m$ ans of giving our government some idea of the interests and desires of the people reluting to these matters. However, I have a feeling that the lumber. industry, gun end ammunition manufacturers, sportsmen and other sroups put much more effort and pressure behind their cesires.

Coneervetion-- Ion It rorks, dage, Rosalie. Mmergency Conservation Comittee, lew rosk City. 1940. 20 p. 
This is a report of the fork done in 1969 by this Committee, namely: passing of the bill to create Ings Canyon lational Eark through campaign efforts; campaigned for aditional area to Clymphic iational Park; worked Ior adition of 6,000 acres of recreational area to osemite Fark; issued publications on conservation (units).

An interesting criticism of the Audubon societies in their organization for training anj service of coservation workers is made.

The bulletin shows how conservgtion workers can work for certain phases and legislative action.

Conservation in Curriculum Building, (a Symposium of Talks), Raymona, Anne; Soil Conservation Service, Southrest region, Albuquerque, New Hexico. Eeptember 1941. 43 p. mirneo.

This eroup of talks was given before an educator's meetine in spokene, ashington. It describes whet had been done in four states of the Southwest (Arizond, Colorado, Utah, New Eexico). Over a period of five years superintendents, supervisors, principals, teachers, and pupils have worked on building their curriculum on their own communities. Administrative problems wilich arose were numerous. Shoula conservation be a separate subject? At what grade level shoula it be started? Is eeography the place for it? That about time in the already crowded curriculum? how should conservetion programs be initiated? Is there any carry-over in the home?

In her talk before the classroom teachers, tine witer tells briefly how units were aeveloped at different epede levels. Fer jiscussion of field trips is very full. At the meeting of the daut Education Group rays of 
carrying out conservation programs uth cattlemen, E.T.A. groups and others were discussea.

The talks given before the School Board members aescribed whet can be done by that group--study eroups, workshops, contact business men, work in hermony with the state planning boards, Goil Conservation Districts and other community efforts to solve big problems.

These talks are written in a nost interesting way and touch on questions asked by those in the eductional field. They descrive what has been done in one section of our country, and are suggestive for other areas.

Fitten for all those interested in conservation, this bulletin shows that an understanding of the basic resources is a necessary pert of all-time education.

Conservation in the Lducation Prograin, Bristow, H. H. and Cook, Katherine \%. United States Department of Interior; Office of Gducation, ashington. Bulletin No. 4. 1837. $78 \mathrm{p}$.

For years Anerica was confident that her resources were unlimited. Over a period of years waste as well as use depleted our natural resources. Fortunately, a nation-tide conservation movement is underway. The Government alone cannot acconplish the full purpose of conservation unless it is accompanied by an effective proram on a nation-vide scale. Neny states have enacted legislation reguiring instruction in conservation in the schools. However, it is through rofessional rather than legal interest that real progress may be expected. Improved practices and extension of conservation education wat on the preperation of materials 
adapted to elementary and secondary levels. Another aspect is teacher education (both in-service and pre-service). Naterials of conservation lend themselves effectively to curriculum planning; conservation cannot be confined to any one subject; the primery concepts can be understood in their elementary form by youne chilaren. Conservation is generally taught in connection ith another established subject such as elementary science or geography. Courses of study cited which include conservation are those of Virginia, Iew Jersey, Haryland, Fennsylvania, South Dakota, Iona, and lichigan. Special bulletins on various phases are issued by Visconsin, California, and Delaware. Nore activity units are being developed. A list of teacher-instruction institutions and courses offered is given. A brief bibliography includes government publications and general references. This is a general survey of educstional programs and What various states are developing to promote conservation. The oulletin is primarily for curriculum planing groups Por it gives some guiding principles for incorporating conservation in the program of instruction.

Conservation in the United States, Gustafson, A. F., Ries, H., Guise, C. L., Hamilton, J. Jr. Comstock Fublishing Company, Ino. Cornell reights, Ithaca, New York. 1969. 431 p. illus.

The problems of conservation vary with the aifferent resources and are associated with the supply of each remaining, the possibility of reneval, present-day demends, and the use of substitutes. The resources of our country are classit’ied as: (1) Soil and water--two-thirds of the United States 
shows erosion in various degrees; streams are clogged; reservoirs are filled with silt. Brosion and loss of plant nutrients are the two soil problems. Crop residues, manure, rotation, and green manure crops return soil nutrients. Tillage, rotation, close growing crops, contouring, strip cropping, terracing and rass reduce water erosion. Forests, Farks, and Grazing Lands: Forests are discussed as a source of material, as a protective influence, as recreation areas, as hore for wilalife, and as grazing lanas. Losses have occurred from fire, insects, diseases and logging methods. Publicly owned forests are usually efficiently managed. Privately omed areas usually have no provision for second crop growth, and little fire protection. Abandoned farms need to be returned and restored to forest growth; forests protect watersheds; wildife should be on a sustained yield basis. Measures to insure continued forests include protection from fire and insects, regulation of grazing, conservetive logging, increasing public ownership, reforestation and practiced forestry. Farks are usually well inanaged. Grazing lands need restoration and proper management. (z) Jilalife--food value, business, aesthetic value. Decline has resulted from settloment of the country, destroying habitat, pollution, over trapping, lack of food, and other causes. Conservation measures include legislation, refuges, restocking and education. Organizations concerned with the protection of milalife are the United states Bureau of Biological Survey, Soil Conservation Service, Bureau of Animal Jusbanary, Bureau of Entomology and Plant uarantine, National Park Service, the Audubon Society, and state agencies. 
(4) Kinerals-of vital importance to the industry of the nation. The reserves of coal are istantly exhaustible; knom reserves of oil ano gas are definitely limited; iron is plentiful, but known reserves of gold, copper, zinc and lead are limited. Reaucine waste from ninine, separation processes, economical use of finished products, and the use of scrap are conservation methods.

The complex problens of conservation are presented in a non-technical and general ay. Our resources are in varying stages of depletion an must be treated accordingly. This volume presents the basic facts. It gives a good understanding of current problems. For adult students and other interested readers it gives a good general backgrourd of informetion on conservation.

Conservation of American Pesources, Mlliott, Charles N. Turner E. Jmith and Company, stlant:, Georeia. 1940. 872 p. illus.

The subject matter of this book is presented in twelve units. Unit $I$ deals qith all resources, pest and present, attitudes tokaj conservation, and reasons for wateful exploitation. A definition of conservation and all it inplies, and a discussion of what may be expected in the future through conservation activities is given. The other eleven units deal ith the resources--(1) game birds, (2) Eame aninals, (5) fish, (4) forests, (5) national perks, forests, monuments, and state parks, (6) land, (7) weter, (8) minerals, (9) animel and plant life, (10) landscape, and (1I) planned conservation. In each unit a picture of pest and present conditions is iven, vith conservation practices which have 
been and are being organized and winich would be practical. At the end of each chapter withir the units are questions and suggestions for activities, as well as excerpts or special messages from fifty of America's conservation leaders. Wany codes and pledges which may be applied to conservation problems are siven.

The presentation of subject matter is most pleasing and interesting. The languge is simple lall technical woras are defined in the apoendix). The naterial is closely releted ith history ana social studies in that it ghows tine epiect of Anerica's expansion (territorially and injustrialIy) in the exploitation of her natural resources. The oranization is such that the units may be studied as they are needed. The supplemental reading is full and up-toate.

This is an excellent basic text in a conservation course or as a supplementary reader or source book. Frimarily on a junior high school level, parts could be used at a sixth grade level. The pictures, messeces, and eneral oreanization nake this excellent teaching naterial.

Conservetion of our liational Resources is cur sest fational

Defense: Noenaker, Carl D. National Vildife Federation Bulletin. Vol. 4, No. 2. Jashington. Februry Isug. p.6. ve in twerica are faced by an cheny of iar ereeter power por destruction than could be inflicted by any foreign eneny. Tis eneny is vithin our very bounoreres. This enemy is sttackine our potential national security. our netural resources are the erestest bulwark against invesion. re possess. e con best stronetien our national äefenses 
by preserving and restoring these resources. This ereat enemy includes soil erosion, floods, droughts, fire, and wasteful use of forests.

This article points out what has happened to our country and deplores further exploitation. The article should be of interest to all--conservationist and the general public.

Conservation of Cur Natural kesources, ilaveneyer, Lomis and issocistes. The hacilian Compeny, Wen York City. 1900. $541 \mathrm{p}$. illus.

we real purpose or intellient conservation is to guera aetist "vilful waste"-a problen of efticient development ond ise utilization. Hthin the borcers of the United states are the ereatest natural potentialities of any nation on carth. This cnomous realth has een the besir of American prosperity. The principles of conservation are different for the different resources, yet concervation of one resource is closely releted to that of othors. It is en interlocking subject. Van's place is one wich is considered (aisesses, accidents, labor, eto.) as mell as his cocial ana industrial obligations reletine to the resources. Uach resource is considered seperately uith regard to existing conditions in 1960 and possible bettering of the situation. Wherals, wich are far greater in the United States than in any other nation, need an educational procram an intelligent leeisiation. vater, an ever renevable resource, shoula be usea as much as possible. our porests are vest and of exceptional value rom an econoric standpoint. The original forest area has heen greatly reauced by numerous forces. Forest hepletion results in econonic injury to ell. 
Creatly neejed are educationel propems, good forestry practices, refinement of logeing, milling and manufacturing processes, reforms in taxation of forest lands, research and regulatory legislation. The demande for egricultural lends are less ureent, but we need to keep soils in high state of fertility. Depletion of soil though erosion and loss of essential elements is discussea. Jetter farm practices, soil management, and tenure policies have airect irfluence on the groductiveness of soil. "Ildifle as an aesthetic, recreational and econonic resource is aiscussed. me feaeral, state, and privete associctions working toward conserving our vilalire are considered.

This book was written by a roup of seven men, each an expert in nis field. Jesea on tan ise's rork ot 1910 , the basic principles of conservation are the same now as then. This is good foundational reading in conservation problems. The situation in relation to the different resources is constantly chanding. Research and experinent introduce new substitutes and industries, new projects are Insticted, new services are offered by federal ana state governments, and estimates and igures have altered. For an up-to-date account of our resources, this ork would be of guestionable use. For basic principles and knomleases it is excelient for advanced students.

Conservation of Our Natural Resources, Holres, J. S. North Carolina Depertment of Conservation end jevelopment, Division of Forestry, Galeigh. Narch 1, 1940. Circular 10 . 4. \& p. This bulletin, propared on junfor or senior high school Level, gives a enerai overview of conservation and natural 
resources.

Conservetion heans perpetuation through wise use. It involves utilization without waste and reeneration ithout dininuation. The natural resources associated wi th a conservation program are soils, waters, forests, minerals, vildlife and humen. The agencies working toward achievenent of conservation development are the United States Department of Ariculture (Forest Service, soil Conservation Bervice), United states Department of Interior (Biologicel Survey, National Fark Servicel, North Carolina Conservation Department and Agricultural Extension Service. Runerous civic organizations have active interests in conservation.

The leaflet might be used in an approach to conservation problems wie in scope.

Conservetion of the Nation's Resources, Flyn, $\mathrm{T}$. T. and Ferking 9. F. The Tacmilian Company. New York City. 1941. 373 p. illus.

Anerics is a lend ot reet weelth in resources--joth natural and human. The location, size, and climate are among our resources. The natural resources are: (1) Vater--the conservetion problem is to use as nuch weter as e can. Vater has many important uses-for agricultural purposes, power, navigation, disposal of vaste, home for wilulife, and recreation; (E) Tegetation of to kinds is considered, (a) forests which ere needea for lumber, to control erosion and to hola the ground vater table. Great waste has resulted from fire, insects, diseases, and inessicient lumbring and m nufacturing. Reforestation has been started, but a much expanded program is neeaed. (b) Grasslends are needed as 
cover for soil, and as a source of food supply for cattle and sheep. Fire, overgrazing, and cultivation have destroyed great areas. Reguletion of crazing, seeding, and non-cultivation are the vest remedies; (b) Land--efforts to conserve the public domain have culminated in National Forests and Parks. Two acute problems of soil conservation are replacine plant foods and erosion. Crop rotation and fertilizers vill restore the food. Nany varied pro rans are needed to control erosion. The problem of tenancy is a factor also; (4) wildlife--increased popultion, good roeds, the auto, orainace, and pollution have taken their toil of mildife. To restore it e need increased education, legislation, and refuges; (5) Minerals--our minerals, both metals ana fuels, heve been exploited mainly because ot' competetive practices. Other losses have resulted from minine, smelting and inefeicient manufacturine nethods. ve shoula use substitutes, buila up scrap piles, and control price fluctuations to meke our minerals lost; ( 6 ) thrmn resources are the most important of all. The problems of health and safety are foremost. Terious agencies work for better personal health and public health. Safety in industry, in a riculture, on the hichyay, and at home is of vital importance. Social security and education are also means of humen conservation. A flexible total plan for using our resources in accordence uith social justice is needed. The planning for conservation in this country is under the direction of the National Resources Planning Boara; commity, state, municipal and regional plennine is also unaer way.

This study of the multiple problens of conservation gives 
a broad view of all our resources, and stresses social attitudes toward them. It emphasizes the conservation of natural resources to the extent these resources are used for the welfare of the people.

ritten as a text at high school level, it is interesting and mell balanced. Review and dscussion questions for each chapter are splendid. The biblioraphy is up-to-date; films available for each topic are listed.

Conservation Practices in the Elementary school, United States office of vacation, Information Exchange, rashington. 1941. $30 \mathrm{p}$. mimeo. (No longer obtainable)

This is a group of articles, descriptions, and one unit (on erosion) which tells what has been done in various schools in studies of conservation. They are brief sumaries of activities for daily lessons which teachers huv written. The material is inadeouate since no aescription of the unit or content naterial is given. The reader knows nothing of what has gone before and is at a loss to understand the purpose of this material. We bulletin is of little or no value since the instances cited are entirely unrelated to eech other or to any continued prozram.

Conservation, The Resources ie Guard, United States Depurtment of Interior, ashington. 1940. 29 p. illus.

Tre United States has more natural resources than any other nation on earth. 411 the efforts toward the vise use of these resources is called conservetion. The Depertment of Interior is composed of agencies whose duty it is to heIp guard our netural resources. These agencies and their functions 
Gre listed: namely Bureau of Reclanation, office of Indian - Affairs, Geological Survey, bureau of Mines, the Fish and VIldife Service, General Land Ofice, National Fark Service, The Grazing Service, Bituminous Coal Division, The Eonneville Tover Administration, Fetroleum Concervation Division, Soil and roisture Conservation, Division of lerritories and Isiand Fossessions, The Fuerto Rico Reconstruction Division.

A bibliography on conservation naterial (available from Supt. of Documents, United States Government printing office) is given.

This is a very handy leeplet in that it gives briefly the vork of each agency listed above. On a hich school level, it would furnish easy reference to any eovernment agency concerned lith conservation and its work.

Conservation rorkbool for "Tomen, Tennessee Department of Concervetion, Educational bervice, Gduc. Fub. lio. 7 . Narch 1, 1941. 27 p. 1llus. Nashville.

This mide briefly diecusses Ternesse's six basic natural resources--soil, ater, forests, wildife, minerals, scenic and historical sites, and the work of the conservation Depertwent. Then are eiven suggestions as to what wowen, as individuals and as clubs, cen do to help solve conservation problems. These suggestions incluee preperation of news releases for county and city nerspapers, sponsor activities in connection with schools, aid in develcrment of comunity Popets (hature trails, bird sanctuaries, cerdens, etc.), erect signs for fire prevention on highays and in vooded areas, minter feeding of birds, roadide planning and demonstration areas, develop roadside parks, and aid and sponsor Conserva- 
tion Sumner Vorkshop programs.

This handbook gives many usable suggestions for wornen's groups and their aid and advance of conservation. It should be a great help to garden clubs and other orcarjzed groups. ujurce naterial in the form of publications and movies available frofin the Tennessee Jepartment of Conservation is listed; these mould be of value to teschers.

Conserving our Natural hosources, American Association for the Advancement of science. 1957. I2 $\mathrm{p}$.

This is an annotated list of books which give a backeround for understanding, anù a select list of reliable up-to -ate books and phemplets on current informstion relating to conservation. The list covers (1) Eeneral conservation, (2) Iena use, (3) forests, (4) vator, (b) oil and gas, (o) minerals, (7) wildife, (9) ma azines dealing with ceneral and specific conservation topics.

The reading level of this raterial is on a senior high school, college, and adult one. In compiling meterial, this learlet would be of value to teacher, librarian, or one in want of eneral inforation on conservation.

Conserving our gesources, Keso, Edvara I. Times-Journal Publishina Company, Cklahora City. 1940. 201 p. illus. Anythine that nature provides that is necessary for living or a better enjoyment of life is a natural resource. The resurces considered are soil, forests, vater, minerals, and willife. Two ohapters ere aevoted to each of the above topics. The picture of our country and the uses made of each of these resources is given. Then a aiscuseion of that nay 
be jone to replenish such resources as are renewable, and what may be done to best utilize what we have lert is given. The various netional and state agencies working on conservation problems are nentioned in connection with each topic. The various kinds of parks, and their place in conservation are noted. Resources poula have little value if there vere no people to enjoy or use thent, and in many ways the human resource has been neglected. Ehysical defects, diseases and accidents cost much in time ana noney. Lencies working for conservation of our people are the United States Department of Health, state departments, the Red Cross, and others. The final chapter gives an account of conservation in Oklahoma. Mechanical methods of erosion control, terracine, strip croppine, and eully control are used to save the soil. ater is a big problem in that state, and roservoirs and flood control projects are under vay. The shelterbelt, tree nurseries, and forest service prosrams are described. Mneral resources are mentioned, but no predictions for the future are given. The state fish hatcheries, came refuges, and $v$ rious organizations have furthered the study and conservation of $\operatorname{sil}$ iffe. The State Board of Health, State Highay Fatrol, and others are working to conserve the human resources.

This account gives general view ot our country and the condition of our resources. No details are given, and the naterial is rather elenentary and superficisl in presentation. It is witten in simple, easy language. since this is a text intended for use in junjor high school, it is gooa meterial for a beginning course. Farts could well be 
used by fifth and sixth grades.

Cornell Rural Bchool Leaflet, New York Etate Colleee of Agriculture, Corneli University, Ithaca. Vol. 32, No. 1. Septernber 19:8. 75 p.

This leaflet, designea for teacher use, gives material on the elementary science library. Every librarian and teacher responsible for guiding chilaren is confronted with the probleas of book selection. Standerds for selection are (I) the content should (a) ada to the child's store of appropriate and a esirable knowladge, (b) be of sufficient literary and artistic merit to foster an appreciation of the beautiful; (z) it should be character-forming; (z) the form or make-up should be consiaered.

In the list of books eiven, librariens and science specialists considered them with perticuler attention to science content, presentation, and rake-up. Annotations incluce type of material, and grade or age level. The topics covered in the list are general nature study, animal life (mainmals, birds, fish, amphibians, reptiles, insects), plant life (flowerless, flowering, gardening, forestry), the earth and universe (stars, sky, ancient life), and physical science. This list is excellent and every teacher should be familiar with it if she is compiling books for any phase of nature or science study.

Cornell Rural School Leaflet, New Tork State College of Agriculture, Cornell University, Ithaca. (Teacher's lio.) Vol. 34, No.1 September 1840. 65 p. illus.

In this number, for teacher use, are given many and 
varied field experiences in natural science in elementary schools. Thines to do or glaces to go are given, then follo. -up activities or auggestions are planned. No teacher could or would desire to do all these experiences, but could select tie ones which would neet her own needs. The field experiences suggested are (I) outuoor temperatures in foll and winter, (2) stuay of evergreen trees, (2) a snowbank, (4) electrical transmission line, (5) speed of sound, (6) cameras and picture takine, (7) visit a gravel deposit, (3) shapes of pebbles, (9) visit an eleveted place, (10) Visit a road cut, (II) study of a well, (I) study North Star, Dippers, (13) study of an unpainted builaing, (14) visit a pile of junk, (15) visit a filling station. At first glance, these field experiences seem to be made at rendom. However, their use in making meps meaningful, soil erosion, electricity, sound, air, physical chanees, etc. are excellent. These field trips nay be fitten in their proper units or programs, and should nake the study of science and nature more interesting and concrete.

Gornell Rural School Leaflet, Now York state College of Agriculture, Cornell University, Ithaca. Vol. 50, No. 1. September 1942. $65 \mathrm{p}$.

The purpose of this leaflet is to suggest aids to teachers in the teaching of ar and conservation. The cartoons may be redrawn on the blackboard and help aevelop a sound philosophy. Arong the major problems are those of personal safety, of health, of food, of trensportetion, of elinination of waste, of power, and of getting alond together. Under each of these general topics the subtopjcs are illus- 
trated--as in the problem of health (I) naste disposal, (2) insect menace, (5) municipal price, (4) war, health, and local fooả.

The bibliography for teachers and elementary school children is very good.

This leaflet would be useiul as supplementan material. uince illustrative material is hara to ind this type helps supply the need.

Creepins, Sprawing, Clinbine Elents, Comell Rursl school Leaflet, New York State College of Agriculture, cornell University, Ithaca. Vol.5., No. 4. Warch 1930. a p. illus.

In this leaflet are described the sprawing and creeping plants (knotweed, purslane, carpetweed, chickweed, etc.), lower-garaen sprawlers (nasturtiuns, tanderine Jew, sedums, pansies, sone violets, etc.), sprawline house plants (asparagus fern, ivy, etc.) pasture end lawn creepers (olover, wila crane's bill, moneyort, eround ivy, bindwed, etc.), and marsh plants (Iiverworts, water ferns, duckweed, etc.). The cover and root protection given the soil by such plants is emphasized throughout. The descriptions and ereral habitat should enable chjloren to find and observe these plants.

In a study of erosion problems, or a study of plants, this leaflet shoula be most helpful.

Curriculun content in conservation for glenentary schools, Bathurst, sffie $G$. United Gtetes office of ducation, ashington. (Bulletin 1959, No. 14). 1940. 79 p. The activities required for studies in the fiela of con- 
servation are varied with respect to the nature of the resources studied and the inclination and needs of the pupils. Systematic instruction can be achieved by placing empiasis on different phases of the subject or on aifferent activities at definite places in the arriculur. other plens consider the seneral rroblems of conservation as one metor social interprise in phases of which chilaren participate from year to year. Gome classes dovelop thair stuay around each of the country's resources. Wach teacher will necessarily organize material to the needs anj interests of her class. This bulietin presents the resources of wilalite, min rals, water, forests, and soils. Activities and techniques are eiven under these headings: (1) understandings to be aevelopea, (2) participerion in activities, (b) attitudes and continuine interests.

Mis bulletin for teachers suggestseducative values of conservetion in their reletion to curriculum content. The teacher can consider then in her bias and cen better help her pupils to perticipte in conservation enterprises. The activities include nany end voried experiences. The bibliogrephy is good.

Developing the Erogram of Conservation Lucetion in Ohio, Pink, Olie ت. Science Budution. Merch 1941. Vol.25, Io. 3. $7 \mathrm{p}$.

conservetion educetion will be included as a nejor concept in the revised elementary cursiculur in chio. careful planing is most necessary. These plens beein in the first erade. Sach grade advances from lie foundation of uncierstandine established in the precedine units. Uinits carefully 
planned should have sequence, and depth. A great choice of activities vill provide the opportunity for each teacher to travel paths according to her creative interest, proviaed she guides the class tomara the goal, "the conservation ay of Iiving." In the elementary school the primary emphosis mill be on the science principles; in the socondary school attention will be piven to the social and conomic implications of the interrelated conservation problems.

In this nev program "teaching the teacher" is of importance. Literature for the teacher, conservation labratory for teacher training (established in Zalaski ctate Forest) and assistance in the development of proframs for teacher training institutions have all been instigated. Units are being outlined, Iiterature cited, and plans for continued development are unöer way.

This brief sumary of ohio's plan is a very interesting article. All curriculum stuajy groups should be interested. Developing the lew Program of Conservation Bacation in Onio, Fink, O. E. Reprinted from Ohio Schools. January 1940. Colunbus. 4 p. illus.

In Ohio the state Department of Baucsion and the Division of Conservation and Natural Resources are co-operating in a curriculum project in conservation education. Objectives of the project are to give the pupils (I) insient into the nature of the morld, the interrelationships of nan and other forns of life and the physical world, (z) information, habits, and attituaes conducive to health, (b) growth through a variety of purposeful soientific experiences, (4) emotionalized attitudes to ard the naturel environment and its interrelationships, 
(5) ability to solve problems through an examination of evicences, (b) villingness to act inteliigently on the basis of evidence and (7) a sense of social responsibility. Units, materials and techniques are to be morked out. The units aeveloped should contain scientific principles which are to be taught, activities, and lesining situations.

when this bulletin was issued ohio was just beginning the project in conservation education. This is an explanation of the basic principles of conservation and the coals tovard which the schools expect to work.

of special value to teachers of onio, the article might well be used by any group initiating such a project. Development of hesources and stabilization of mployment in the United States, National Resources Flanning Boord, :ashineton. House Document 1:0. 142. Jenuary 1941. 409 p. The objective of public works construction is to provide public facilities required for the maintenance and progressive development of the standera of living of Americen people. Tunctional development policies are plenned on a six year basis. Lend-use objectives are closely related to public works. Fach specitic proposal must be consiaered as to costs and benefits, financine, timing, and regionel plans. There should be a unified national water policy based on adecuate, reliable data. Froper account of social and economic benefits, prudent financirg, settlenent of controversies dver interstate vaters, orderly priority as to needs, and other points must be considered. Objectives of energy resource develophents are (I) to develop energy resources with a view to a strengthened netional economy, (2) provide effective measures 
for coping vith national emergencies, (3) promote better understanding of the problens of conservation, (4) provide for continual planning and investigation. Specific objectives for coal, petroleum, water power and electric enerey are peculiar to each resource. The projects recommended for 1942 in six major catagories are listed: water use ana control, land, transportation, defense, government plant, and housing. Regional development plans for each of the ten regions are given.

These recommendations are the framework of a long-range policy of plenning. They include a six year program of public construction and a statement of related future policies and plans of the Federal Government. Frepared mith estinates, surveys, investigations, it gives an over-view of recommendations to meet employment needs and efficient use and develooment of our resources. Frimarily for Congressional legislation, the recional studies could well be used in adult courses in geography, economics, ana conservation.

Education in Conservation, Vational wildife Tederation, washington. March 1940. (Comittee on Laucation Fhamplet (vo. 2). $39 \mathrm{p}$.

The seneral objective of the National wilalife Federation is the restoration and perpetuation of America's natural resources through an aroused and enlightened citizenry. The task of developing a sound public school program in conservation education has been assigned to the Comittee on Education. The progress of this group is the subject of this phamplet. The fundamentals of the program were outlined and received hearty approval by many leaders and institutions. The next 
big problem was teacher training and materials. Wost teachers are symathetic with the idea, but they simply don't know what to do. Books, phamplets, etc. are numerous but are not on a level that children cen understand. Films, slides, pictures and materials of non-technical nature are the great need.

this aiscussion touches on two vital problens facine conservation education--teacher--training and materials. Wuch is being done and has been do ne since 1940 in both these phases, yet it is a slow process and a complex situation. This is excellent reading for teachers and administrators.

Bconomic Georgraphy, Ostrolenk, Bernard; Richera D. Irwin, Inc. Chicago. 1941. 776 p. illus.

Bcononic geocraphy deals with the study of man's utilization of the earth, its climete, soil, ingredients, and changes man effects in this environment to adapt it to his use. Man's ingenuity brings to light an endless spectrum of resources, yet we need to recognize that these are linited. Optimurn use of these resources has for its first objective the elimination of gaste. Concepts of conservation involve a conflict between the immediste private and corporate interests, and a long-time social interest. Conservation frequently aenanas that pecuniary accounting be ignored. In a survey of our resources we note that the nation canot maintain its form plent unless it radically alters its system of faming. Modern development of our water resources has come to be a mulinle-use activity as evidenced in the T.V.A., Columbia and Colorado River projects. Minerals are discussed as to aistribution, wethods of extraction and industrial uses, substitutes, and new industries. The ratio of total nornal 
forest arain to erowth is now $2: 1$. Conservation of forests is intinately related to aricultural, industrial and social probiens. Forest products are numerous, important, and essential. Taxes, centers of use and risks cause devastation. Forests and their relation to rainfall, erosion, naviation, and water power are discussed. ultiple use of national forests has been adopted and should extend to private ownership. The foremost conservation problen facing man is to learn to live peaceable. This brings us to problens involving social, political, and economic factors. Education must take an important role in this problew.

This very complete and detailed acoount of the problems of the productive activity of the people in terms of natural resources covers every phase of our resources and the industries relating to them. The role of covernment, the force of technological development, and the consequences of the changing interactions of resources are stressed. Geographio, economic, and social aspects which are a part of the development of the resources are discussed. The naps and statistical data are nost helpful. The bibliosraphy is excellent. This materiel coula be used at college level in courses in economic ceocraphy, geography, and conservation.

Facine Conservation Facts, (Amnul Report for 1936) Imergency Conservation Comittee, New York City. Fub. No. 00.1937. $10 \mathrm{p}$

In 1936 the Committee published eicht phamplets, worked for the saving of the bugar Fines in Toserite Park, the establishment of rount Olympus National Eark, supported Dr. .... T. Wornaaay in his work for a closed season on migratory waterfowl, 
improved llawk lountain Sanctuary, helped launch the Northwest Conservation League.

The Committee cooperates whenever possible with all who work along similar lines, and urges all nature lovers and those interested in saving our resources to work with them.

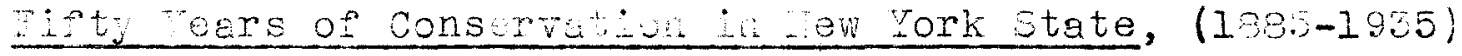
Whipole, Gurth; Conservation Department and New York State College of forestry, 1955. 199 p. illus.

hile Europe sent spoilers and the probenitors of spoilers she also sent consarvers of the forest. Intermittently, in Colonial times, voices were heard urging action for the protection of the Alerican wooks. As early as 1698 governors of Nev York were advocating forest protection and forest production. Controversies started, lemislation was proposed and failed, but in 1335 the Forest Comission was authorized. Hany administrstive problems were before the Comission. Logging operation, trespassing, lar acouisition, taxes and other problems vere to be aecided. Porest fire prevention and control was one of the major issues, and 1805-1910 saw the pirst tower-patrols built. The Conmission turned its attention more and more to reforestation and forests and fishery departments were placed in charee of scientifically trained men under civil service. Fore attention as directed to protection of wildife, and in 1913 steps vere taken to begin recautional developients in the tate Farlis. Fubic education--lectures, publications, nenspaper releases, movies, etc.-mas put on a comprehensive basis. Comprehensive land surveys were initiated, hatcheries and eame rams were 
built, proprams for control of disease and insects were begun, forest schools were arraneed, and other probressive plans were laid. Conservation in this state is a personal matter with tvelve milion people. The work of the Conservation Department touches every section of the state; durine the fifty yesrs a solid foundstion of administrative work has been leia, and a continuous policy established, both of which enable the state to hold its eains and to make new advancements.

This history presents a connected story by tracine events from cause to efiect. It is concerned chiefly with the legislation of the state as applied to various aspects of conservation. It could vell be used as a text in senior nigh schools.

Film Loan Iibrary, Tennessee Department of Conservation, Nashvilie; Macstional Tublication No. 3. Unjated. 6 p. mimeo.

The daucational service of the fennesee jepsrtinent of Conservation maintains a film loan library for the venefit of schools and conservation minded organizations. Films may be borrowed free of charee. Joti sounà and silent, colored and black and white filins are available. Thirteen films on biras, fishing, duck hunting, eme frrms, forests, and minerals are available. Other agencies (United states Department of Interior, Department of Acriculture, National vederation of mildife, etc.) also have films on forests, gane, rivers, etc. Wach film is described very briefly. This list of availate films should be especially useful to teachers, and to leaders of conservation groups. 
Good References for Conservation Education in Elementary

Schools, United States office of Education, Government Printing office, washington. 198. $16 \mathrm{p}$.

This is a list of selected publications dealing with conservation topics-birds, erosion control, floors, flowers, hunan life and health, minerals, nature trails, soil, spiders, trees and forests, wild animals. Listea are for ty books, phamplets, etc. on basic iactual material, and ten on nethods of instruction. Each book listed is annoteted and grade level given.

This list would be helpful in eathering references for teaching any of the phases of conservation listed above. Sources of visual materials and periodicals are Iisted also. Helps in Teaching Conservation in visconsin schools, Misconsin Departient of Fublic Instruction, Madison; Curriculum Bulletin Vol. 1, No. 2; Nay 19z8. 102 p. illus.

Fart 1 of this bulletin gives a bibliography for soil resources, water resources, minerals, scenic and historic resources, forests, and wildifie. The biblioraphy for each resource is given by grades-one through eight. Fart 2 is concerned with teaching methods or procedures for each grade. These activities are integrated with reading, language, mathematics, social studies, and art. They are varied and include all types of approaches and methods--reading, writing, excursions, experiments, collections of material, making notebooks, etc. These activities are intended for use in elementary graues only.

This is an excellent guide for teachers for it intesrates all phases of conservation with all the other closely related 
educational activities in the grades. The experiences are varied to take care of all interests, and are very worthwhile.

Injustrial Location and National Resources, National Resources Planing Soard, Jashington. December 1942. $352 \mathrm{p}$. illus. The selection of a locetion for a menufacturins plant usualy requires the weighing of a number of interrelated factors. Froduction and distribution problems require consideration of the sources of raw and semi-manufactured materials, fuels and power, needs for special labor skills, availability of manaement, transportation, and service pacilities, water supply, and narkets. Oreanizational factors wich influence the locations of particular industries are size of the plant, extent to wich operetions can be integrated ith related processes, and the proxinity to other industries. Contrary to common belief, the ereat majority of manufacturing plants do not use basic raw materials directly. When materials are perishable or when processing results in great weight or bulk reductions, locations of plants are necessarily close by. Industries dependent on foreign sources for inaterials tend to be tracted to seaboard locations. Mineral resources (fuele) are usually more localized geographically than are the leading non-metallic resources. Nanufacturing is concentrated mainly north of the onio and east of the rississippi. It is, however, reaching out to new regions, particularly in the Southeast. Food production is concentrated for the most part in the eastern half of the united States. Iish resources industries are larely peripheral, the est coast states being the most productive. Fibers, furs, and hide industries are 
concentrated in a few areas (Cotton Belt, Louisiana). Forest snd lumber industries occupy the outer portions of our country.

This report is an analysis of the various factors influencing manufacturing location decisions. The problems of making such aecisions are outlined. It shoula be helpful to botr private industry and eovernmental agencies faced with problems resulting from wartine industrial expansion and conservation to peacetime needs. It should aid in developing a more stable and productive economy.

Looking Anead with lennessee Schools, State Depertinent of iducation, liashilie. 1987. pp. 3-250.

This is a bulletin on the improvement of instruction for lennessee. It eives the aims of the curriculum comittee -making the leamer's needs and purposes the first consideration. Sfective learning comes through mesninetul experiences so the committee has presented many units--prom eirst grade through hieh school. These units are esed on situstions applicsble to conditions in lennessee. The units on reforestation, erosion, comunicable aiseases, improvenent of ferm homos, water suply, and agricultural problens give many and veried sugestions.

Since no unit can be taught exactly as written, these should be most helpful, for various approaches, activities, and source materials are given.

The bulletin is to be used by teachers and should be of aid in organizing materials.

Louisiena Conservation, (a collection of brief hadio Adaresses), Louisiana Departnent of Conservation, wew orleans. 
Eulletin No. 25. 1954. 272 p. illus.

In 1903-34 the Young wen's jusiness club of New Orleans sponsored a series of radio adaresses on conservation and the rork of the Conservation Department. These aduresses vere given, usualy, by the chief-of-staff of each aivision within the depertment. The topics covered nene mev orleans - Conservation Center of the southland" in which the spoaker emphasized the physical characteristics or the state and city in relation to industries based on natural resources. Other adjresses were on fishine, mineral developnents, forestry, wildife, the oyster industry, educetion, comercial fishories, sea shrimp industry, end scope, purpose and accomplishments of the Departinent.

In observance of conservetion teek, 1931, a sililar serios of radio adaresses were nade on topics of education, science, sea fishories, ildife, selt dones, the oyster industry, forest resources, minerals, and the importance and value of conservation.

These adaresses were interestine and educational. They presented the meny spects of conservation and its influence on social dnd econonic conditions. They stressed educstion of the people of the state. By raijo and literature surely many pople of the state were reached. Non-technical, they sre easily read and understood. The bulletin should be of aid to ther stetes and agencies in planing a propran of educetion in conservation. schols could de tue adresses on the oyster and shrimp industries for they are very complete.

Louisiana Conservation Feview, Louisiana Department of Con- 
servation, New Crleans. Illus.

This masazine, edited and published by the Louisiana Depertment of Conservation, is issued quarterly. It contains the reports of the Department. The issues, 50 to 00 pages, are concerned with all phases of conservation--research, educationel prorams, and industries related to natural resources. Fhotoraphs end statistical date are presented in a pleasine gnu uscble maner.

The agrine is furnished free on reguest to citizens of Iouisiena, to nulic schols, libraries ena scientific institutions throughout the Urited Gtates and foreign countries.

The magazines reflect tie trend of affirs in conservation, and the problus met in Louisiane. Surely of ereat interest and value to Louisiens folk, it is a fine example Por other states and conservationists to note.

ichison Deportrent of conservation, Its orsanizetion and

Furctions, Department of Conservation, Lansing. Fovember 12.7. I0 p. mimeo.

The ichisan Department of Conservetion was orfanized in 1921 by legislative ect. In 1867 mineral resources attracted the attention of statesmen. Fishing protection was recognized as a need in the seventies. Forestry has developed ith national forest affairs.

The pepartment has two airect sources of revenue, (1) Lepicletive appropiations, and (2) Game Erotection fund (Iicenses).

Divisions of the Department are (1) Forest Bire Control, (E) Law inforcement, (5) Game, (4) Fisheries, (5) Land, Forestry, (7) State Farks, (8) Geolobical Survey, (9) Educa- 
tion and Fublic helstions. The function of each division is given.

This is a brief synopsis of Michiean's Depertmert of Conservation--how organized and the work carried out. It could be used by sixth graders as an overview of the vorkines of a conservation department.

National Defense and Conservation of hesources, tienner, Geo. T. Frontiers of Denocracy. Warch 15, 1841. pe. 182-185, April 15, 1941. pp. 216-217.

After a mere 150 years of national existence, sone $35 \%$ of our useful "nila game is gone, $30 \%$ of our timber has been cut, $6 \%$ of our visible petroleum reserves used, $67 \%$ of our lead and zinc, ol, of our copper, $40 \%$ of our iron ore, $55 \%$ of our anthracitecol, our fisheries are well over half depleted, 10; of our cultivated land is ruined beyond repair. Yet our business life has been geared to peace rather than var. Our defense proeram is creating a newer and biger problem, and vill cause us to reach the exhaustion of our netural resources much more speedily.

The solution must obviously be controlled programs of resource conservation. Different kinds of resources call for different kinds of treatrent. The total program must include physical planning, and manegement for some, socioeconomic planning for others, and nationel ounership and socialistic control for still other resources.

ritten for adults, this article plainly states what our ereat var proeran is costine us in natural resources. fhere is heedeas waste with little or no planing to conserve. It brings to sight the future unless sorie rather 
drastic action is taken.

Mation l aesources Boerd Report, Ivational Resources Board, December 1954. 455 p. illus. Vashineton.

This report is the iirst inventory of our national assets and the problems related. It covers the national plarning and public works in relation to national resources, including land use, water, and minerals. The recomendations cell for continous plenning for (1) Land-use--(a) retirement of submareinal lands at the rate of milion acres yearly for the next 10 years, (b) aditions to netional and state parks, forests and wilalife refuges, (c) mobilization of national, state, and local efforts to control erosion, (d) debt reajustment, compulsory compensation for improvements made by tenants, (e) range policies--extena l'aylor Act, more data on recreationsl possibilities; ( 2 ) vater--(a) pemanent rater Plannine section, (b) assemble data, make full use of knowledge and experiences, (c) studies of drainace basins as a whole, (d) develop more productive uses of vater resources; (3) Winerals--(a) permanent clannine agency, (b) legal and economic problems studied, (c) place on a basis of economic stability; (4) Hydroelectric power--it is desirable to provide all sections of the country mith electrical pover at a low cost, use electrical poiner as a conservation to seve other fuels. A six yesr budget of construction for public orks planning is outlined to care for employrent and physical developrent of our resources. Basic date for plennins must include (1) financial balance, (2) populetion trenas, (3) mapting, (4) climetology, (5) water studies, (6) soil ana (7) vegetation studies. Regional 
problems relating to lend and rater resources, and detailed comittee reports on lend, vater, and minerals are given. mis report is aignificant and interesting because it is the lirst attempt ever made to list just what resources our country has, and what rethods can be used for future cooperation. Our country is not as baa onf as it might be, but mach needs to be done to insure future security and opportunity. The pictures and maps accompanying the report are excellent to supplement the material. Nost of the naterial is too technical for the Isyman; parts coula be used by college students in courses in reography, economics, sociology, and conservation.

National Resources Developnent Report for 1942, Nstional Resources Ilannine Bosrd, Vashincton; House Docunent No. 560. 1942. $227 \mathrm{p}$.

The Rational Resources Llanning Boara offers a series of reconmendations for the transition period and the longer range period of post-ar development. These are: transition from lar to peace (demobilization of Armed Forces, war plante and economic control); (R) expanding econony (private enterprise, finance and fiscal policies, physical facilities--transportation mojernization, expand electric power, multiple-purpose water resources, lend development, pollution control, conservation of soil through soil conservation Eervice; (b) services and security (education, health, nutrition, nedical care, employnent and social security).

These projects, some of which ere plamed and in actual production before the ar, have suffered from financial and 
manpower drains. In order to meet the needs of our democracy plens must be laid now

Wis report states some major planning objectives, su marizes planning activities and lines of action to be developod as a post-war promam. These are merely reconmendations to Congress, but they give the layman an excellent ideg of what is beins done, and what is planned for the future on the part of our Federal Government.

Mational Resources Developnent Report for 194 , Ft. 1 Postar Flan and Froeram, National Resources Plennine Bocrd, rashington. January 1943. $80 \mathrm{p}$.

The public works planning includes (I) land developnent ana protection--(a) eeneral econonic problons, (b) rual works --soil, water, forest anä range conservetion, flooa control, insects, plant aiseases, etc., (c) improvement and expansion of services to rural populations; (E) soil conservetion-or sanized on a project area or on watershed bssis; (3) flood control--surveys of ritire watershed on basis of run-off, retardation of soil eroding waterflom; (4) irriation-ganeralized or over-all area plannine and detailed or operational plannine, joint investigetions by federal, state, and local agencies; (5) forest and park long-range policy-recreation in collaboration with resource studies.

Evaluation of public vorks for land protection, development, and use is basea on technical soundness, beneits to exceed costs, consistent aistribution of costs, and hamony with regional plannine. So land may have multiple uses, but each project ill have its omn particular criteria or objectives. ater plans are based rultiple-purpose to combine 
various functions in the sere structure. Frojects for vater use and control form a substantial proportion of post-mar public works proerans.

Recomended projects for $184 z$ in land development, transportation, power, velfare and health, and the surveys under way are listed. 'Snelved" mojects which need legisiation or rurth mork, but wich could be started in a short time are Iisted.

whis is a general overview of the problens wich wil be before our country immedistely after the rer, and pians for their solution. Iegisiation is necessary in nearly al problens. This naterial is for consiberetion ot the general mublic and by those chareca ith airect responsibility for determinine our netional policies. If our country cen move formera as outlined here, all citizens will benefit physicalIy, financielly, and morelly.

Nation Resources Development Report for 1945, Eart 2, National Resources IIanning Board; Touse oi Representetives, Document o. 128, Fart 2. rasineton. 1943. $116 \mathrm{p}$.

The current plenning activities for stabilization and dovelopment as outlined review the accomplishents and experiences of the past ten years. This includes wartime planning for resource use (committee reports), trenas in production, employent, prices and consumption. Fublic works plenning in non ar Eederal construction have been increasinely curtailed. Nost of the flooj-control projects ire at an investigtion stage, and no further work has been done. heclumation projects in eonnection with the rar prosram are being continued. projects to supply essential metals, oil, 
power, fuel, food, land, water and timber needs have been pushed. Post-war prosrans for irrigstion, reclanation, forests, arks, range lana, wilaliie, soil conservation and transportation are such that they can be made ready for early undertaking in the after-ar period. The eleven regional field offices heve made analyses of the resources. Generaized plans for future land use and public facilities are rorked out. Detailed procedures are yet to come. raterial has been assembled to indicete susested post-war datribution of workers in natural resource and nanufacturing activities. State plenning in California, Arkansas, liassachusetts, and isconsin is described. Local planning has incluaed housing, water supyly, sever systems, roads, etc.

This is a complete analysis of how our nation has wet the war enerencies by planned epfort. Many of these plans can be revised, expanded, and carried over to neet post-war nevas. Wany ays of improving and strengthenine the program are sugesstea. This report is rrinurily for consiaration of appropriate legisletion to achieve normal emplojment and to provide for further avelop ent of our national resources.

Mational Resources Flanning Tacts, Trational Resources Cormittee, asinineton. 1939. II p.

The resources of this country vere trenendous. They nade this the "promisod land." The eaer rush to reep the revards of a nation so richly endowed lett a tragedy of vaste and depletion in its wake. Soil erosion has taken a heavy toll. Our forest area has been reduced one-half. The waste of ninerals has been tremendous, especialiy in the field of oil and 
sas.

Theodore Roosevelt, 25 years ago, started the battle to piotect our forests, water resources, and wilife. The need for a planned prosam to preserve all resources has come into recognition.

Today 45 state Flannins Boards have made inventories. Regional planning is shaping (T.V.A.). For the federal Government the National Resources Comitte aekes studies of respurces, social, inuustrial and economic trends and in an advisory capacity recomends proerams and policies for conservation and development of land, nineral, water and other resources. The comittee acts as (1) a clearing house, (2) a research and advisory body, (5) a correlator. The comittee recommenas to the Fresiant and Coneress.

This phamplet outlines the functions of the F.R.C. and shovs that the nation is becoming increasinly aware of the need ror a planned program in regard to our national resources. This could be used at junior hich level in a study of aecrcies worling on the conservation proram of our country. Natural Sciences, (Secondary school Series) Missouri Fublic School Curriculun, Jerferson City. Bulletin No. 6. 1941. $488 \mathrm{p}$

This course of study in natural sciences is designed for use in srades $9,10,11$ and 12. The units are organized in ive sections--(1) eeneral science (air, weter, fire, light, electricity, sound, use of power, food supply, etc.); (2) biology (structure and organization of living things, relation of plants and animals to environnent, heredity, behavior, reprouction, etc.); (c) pinsical science (resources, heat 
and power, use of water and electricity in power production, science contributions to comunication, transportation and health, etc.); (4) chemistry (nature of netter, chemical changes, waters, solutions, etc.); (5) physics (mechanics, heat, sound, light, etc.l.

The unit on conservation and natural resources is jealt ith in the section on advanced physical science. The suggested content includes kinds of resources, problems of conservation (restoration, management, etc.) of soil, water, forests, wldiffe, minerals. In this, and all the units, suggestions are given for field trips, experiments, collections, surveys, etc. Wuch use is made of environment situations in issouri.

The bibliograpy is full and up-to-ate. Visus aids and sources of gaterial are excellent.

The units are vell organized to take care of individual differences and interests. They are ver suggestive and should be valueble in any seconary school.

Nature Frojects for 4-II Clubs, Brooks, A. E. United States Department of Asriculture, Co-operative Extension Hork in Agriculture and Hone Economics, theeling, West Virginia; Oclesbay Fark Fub. No. 4. Una ated. 37 p. illus.

In this work-book the projects covered are birds (building of houses, feeders, collecting nests, field study, identif.ing biras, coloring pictures, photograpiog), insects (collection ano preserving, life histories), trees (leaf collections, fiela study), flowers (flower presses, gardens, terrarium, iantifying flowers).

The use of this work-book is diversified so that some 
projects could be completed by fourth or fifth graders, as well as junior high students. Wuch helpful infornstion is given and the projects are interesting. Farts nay be adapted to various uses and needs.

Ineteenti Annus report of the vepartment or conservation, State of Iniana, ior the year ending Tune 50, 1937; Reprinted from 1937 Year Book; Indianapolis. pp. 301-385. Today conesnetion of natural resources has become one of the most important functions of the etate's eovemment. At no tine in Indiand's history has there been greater public interest in the inportance of natural resources and a nore sincere desire for ise utilization of these resources.

This report tells of the activities of each ivision of the Department of Conservation. Namely: (1) 3tate Parks and Lands end aters (improved camping facilities, new cabins built, roads repaired, new lakes opened, etc.); (2) Entonology lifint aeainst Japanese beetle, European com borer, apiary inspection); (s) Geology (enporced laws pertainine to proaution of petroleum and netural gas, inspected mell and pipe Iine equipment, collected data, investieated darn sites, aided in complation of topographic maps, etc.); (4) Mngineering (arainage, Iand reclamation, stream gauging, inspected roads, briages, arafts for verious projects); (5) Forestry (inspection of classified land, operation of nurseries, reforestation of lanjs, educational talks, experinental research, fire hazards, etc.); (6) Fish and Game (expansion of game farms and hatcheries, fish rescue, opened lakes, research, etc.); (7) Loucational Bureau (fum ished material for many people and groups, motion pictures made available, radio 
broadcasts given each reek, wildife exhibit truck aisplayed at 23 aifferent locetions, published (ovtaor Inaiana," etc.).

This is a detailed account of the work of the divisions of the Conservation Department of Indiane. Of interest to those concerned with conservation programs, it gives a conplete picture of Indiana's work and achievements. It contains much statistical data wich is of little meaning to the average reader.

Opportunities for the Preparation of Teachers in Conservation Education, United states Office of Education, lashington. Fhamplet io. 90. 1940. $13 \mathrm{p}$.

Courses concerned with the conservation of our netural resources and designed for teachers in the elementary and secondery schools are avilable in at least 138 institutions of higher learning in 25 aifferent states. In ten states, courses in conservation are offered in all the etate-supported teacher-education institutions.

In its varied ramifications conservation involves tecmical knowleages which as yet are not adenetely translated into the language of the school. Eowever, there is general arreament that the ultimate access of any nationwije propram in conservation depends upon or genized education. School officials are seeking authoritative buidance on two significant aspects--one concerned ith content material; the other ith school ana class-room procedures. This phamplet is a esiened primarily to help teachers. It is a result of a catalogue stuay. A list of the institutions oferine courses in conservation, titles of these courses, credits fiven and a brief description of e few representative 
courses consititute the information in this phamplet.

Our iconomic orla, Kinsmen, jelos 0 . Thomes Crowell conpony, New York City. 1927. 584 p. illus.

wan is the central animated factor in our econonic

systen. Iis wants have siven content and jirection to proactive enterpriee se truly as his labor has eiven pom to the output. To conrehend our industrial world ve nust "ove a knowlage of humen ants. Man's wants are four fold --onsical, intellectuol, spirituel, anj social.

or the total supply of nutural elenents constituting the earth, wan has learned to use but fen. The term ratural resources is applied to those materials and forces of nature mich man employs incustrially. To give them the compostion ena form necessary to ake them usable, the extractive and hanufacturing systons arose; to rove the pinished product, transportation developed; to heliver cooas to custoners becane the nork of merchants.

The resources aiscussed are (1) plants as a source of food, (a) aninals, (z) textile fibers, (4) foreats, (5) increrals (nom-netailic and metalicic); (b) eneray resources. zach of these is described as to irmortance, distribution, uses and econoritc trends.

This text is an excelient study of the world's supply of ran rateriais, the intricate processes of production, and the econoric system nich nakes available our vast supply of coous. he listorical aproach wakes clearer man's nestery of irdustrial difficulties. A text on college level, it could be used in economic, and as surplenentery reterial ir georaphy, conservetion, or a stuay ô business. Lo mphasis is olaced 
on conserving these raw naterials.

Cur liatural cesources and mejr Conservetion, isrins, A. H. End hitaker, J.R. John Hiley \& Sons, Inc. Wew York City. 15e9. 045 p. illus.

Conservetion seeks to insure to society the maximum beneits from the use of our natural resources. The objectives vary ith the neture of the resource and uses beins nade of them. A aiscussion of the conservtion moverent in Merica takes up the early apreciation of wise use, srowth of the novenent during T. Roosevelt's tine, and present day problens and eiports to neet them. The remainder of the book is concerned aith our natural resources. Emphasis is placed on the distribution of each resource, the problens of waste, use utilization, na tre human factors involved. one section is jevoted to planing end its adventaces.

Each chapter is written by a different person (a total of ad authors), an expert in his paticular field. Though this joes calse auplication, the material is authentic ana, in every instance, well witten in a clear, concise style. Fictures, maps, graphs, to. aid in the understanaing of the discussions. The selected bibliography for each chapter is excellent.

This is one of the best and nost complete morks on our netural resources and the problems confronting the people of America relating to these resources. So e me asures have been and are beins taken, and others are suggested. The facts concerning our resourcas are plainly set forth; their aistribution, their utilization in the past, and the probable future is considered fully. 
As a text for college students, this book is one of the beat. Every phase of our netural resources and their conservation is covered. Nany perts could vell be used in relation to geography courses also.

Qutdoor Living, Cornell Rurel School Leaflet, Nen York State College of A riculture, Comell University, Ithaca. Vol. 34 , ITo. 4. Varch 1941. JI p. illus.

This leaflet eives iaeas for hiking and campine. It describes how to make cooking equiment from tin cane, suggests ays of cooking, plans for a well-belanced veriety of wholesone food, ays of purifying water, putting up tents and building lean-tos, making of beds of brush, etc. on overnight trips, and ceneral care of a camp site. The use of a compass is described, as weil as getting bearings irom stars, and the narking of trails.

Dangerous or annoyine anirrels such as mosquitos, chigeers, aits, bees, etc. are combatted by various means--citronelia, powdered sulphur, etc. Preatment for poison ivy, poisonous roots, fungi, etc. is eiven.

eys of havine fun by watching birds and grie are builaine blinds to watch from,painting grasshopers and watch how far they travel, identifying trees, leaves, etc.

This leaflet would hold great interest for any child who has ever hiked or camped. The illustrations are excellent and very worthmile. Nature leaders, scout leaders, and adults would learn much srom the use of the rublication.

Outaoor tebraska, Nebraska Game, Forestation and Earks Commission, Iincoln. Illus. 
Tis magaine, published quarterly, contains timely and interesting articles concerning activities of the ame, forosts and parks proram in the state of liebraska.

It is important to keep the public informed with regera to conservetion progrems and activities. This megazine serves that purpose; however, there is a possibility thet it caters nore to hunting, tishing and trapping activities than to other phases.

Flaning for America, rallo ay, Geo. B. and Lssociates, Benry Folt \& Company, New York City. 1941. pp. 98-108, 60 a $-448$

Flanning is an organized effort to utilize sociel intelijence in the determination of national policies. It is oased on fundanental facts and various iactors of the past, present and future. Fhysical planning is concerned with conservation and use of our natural resources: our Iand, water, energy, science and technological resources. The United stetes has organized a large and complex tool for national planning. There are a variety of approaches to reeional studies of lana-use; hish technical skill will be needed to solve the sroblems of price, production and onership controls in farm and forest use. ater plannine principles needed ere broad control of the requirements of areingre regions, emphasis on multiple-use proiects, and complete integrated surveys and plans in the pield. In olanning for our energy resources great need lies in the prevention of waste in fuel resources, Ion-time trends in the dtilization of energy resources, and research in supplies of ater power and low-rank coal. Socil planning to insure nutrition and 
health procrams wilch are adequate involves research and education and certain economic arransements. Such planning involves both indiviaual action and social organization. This symposium, each chapter written by an expert, is an inguiry into the social and economic planing of the United states--physical, sociel, economic, area, and defense. It is well witten in a scholarly style but is difficult to understand unless one has a rich and varied background in certain trends.

It could be used as a text in advanced social science, economics, ana conservation courses at a coliege level.

\section{Plennirg for Permanent Benefits from the Land, (A Unit),} Department of Fublic Instruction, salem, oregon. 1939. 31 p.

In this unit, consideration is given to the conservation of resources particularly as it applies to orecon and the Iacific Northwest. The resources are divided into two eroups - renewable resources or products of the soil, and non-renewable such as coal, iron, snd petroleun. The renewable resources are far more important to oregon than a the nonrenewejle.

The content of the unit covers the forests, fish, game, willite, soil, and to some extent, minerals. The activities sucested a varied and vorthwile. The bibliography is very full and up-to-áte. Plrounout the unit emphasis is placed on the practical aspects of conservation.

This unit, for use in the 1 th grade, should ve very suggestive to terchers in hish schools in developing units on conservetion. 
Plents and Animals Live Poether, wy Land and Your Land

Conservation Series, Book z, National Nlalife Nederation, Inc. Tashington. 1941. $48 \mathrm{p}$. illus.

ivery plant and animal depends in some vay upon other plonts and animels. Han depends on all of them. uninals help plants by eating insects and by epreeding their seeds. Plents help animls b. movidine food and homes. The coming of nan chened conjitions. Forests were cut and burned causing any nimals to legve or be killed, anameny places were left where topsoil was vashed a way Gresslanas have been chansed to plowea fields. Fany animis perished because their homes were destroyed. The plowed soil is easily carried away by water or ind. streans vere polluted by sewage and other wastes, thus destroying nater animals.

Frovisions beins made by our government to protect our wilitie are (I) netional p rks, (2) national forests, (s) gare and fish hatcheries, (4) laws, and (5) refuces. mitten for grades five, six, and seven, this little booklet is interestine and simply norded. It would be useful as a suplomentary reader in certain phases of stuay. The accounts are not detailed, but give reliable, eneral information.

Eoiconous Eisnts of yoming, University of yoming, Agricultural Experiment station, Laramie. Bulletin No. 126. verch 1921. 5.5. illus.

Foisonous rants, mile confined to certain areas of yomine, are nevertheless resconsible for losses of consiaerable agnituoe anone stocken. There is considerable variation from year to year; meny deathe are uificult to aiagnose. 
During the pest fen years there has been a very crejitable acivnce made by stocken in attempting to eet acquainted ith the troublesome reeds.

contributing factors incijental to plant poisoning are mercus. crinarily, plants are protected fron onimals

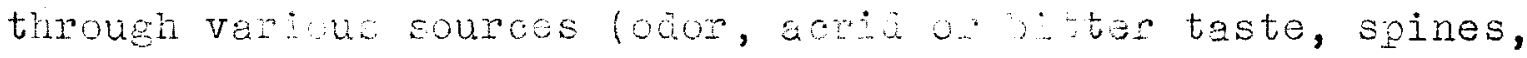
etc.). The depreved appetite for unsus and unapetizing plents is a factor of inportence. The eusceptibility of different species of livestock is e rector of considerale importance.

The principal poisonous plants of nope or less eneral distribution nay be clessified into two roups: (1) those that occur rether enerally and in large quatities over the ststel100o, larkspure, death camas, water nomlock, the lupines, arrow erass; (s) those found locally and in woro restricted areas. These are described as to distribution, animels affected, poibonous period, syptoss, treatment. Inforturatu, prevention carsot be obtainea by raccinstion. Controlled wethods of prazing are the only preventitive neasures iven.

Tis pamplet discusses some of the various factors invIVEd in catte losses from poisonous plants. For the stocknan, it ives some ideas for meeting the groblem.

Poverty or Conservation? Derling, Jay w. Tations "idlife Federation Bulletin Tol. A, No. 1. Vashington. Janury 19.9. P. $2-8$

e rava, as a nation, specialized on exploitation. Conservation is the reverse of exploitation. The functental spects of conservation have jeen, and still are, a blind spot 
in our social, economic, ani political vision. The history of civilization is largely maje up of the rise and fall of expires through the exhaustion of resources. Conservtion is the job of so managing our soils, saters, and eifts of nature thet man's search for these recessities sheil not be in vain. Aerica is no richer then her remeining resurces. realth Wil continue to exist on this continent only so lone as the natural resources of our soil cha gater continue to yiela up their riches in proportion to the requiremonts of our pogulation. When these rescurces are further depleted prosperity standerds of living and sociel contentment among our pople ill vanish. To illustrate these statoments, examples such as the salmon inaustry, the Dust Bowl, ghost towns, etc. are cited. The wetional vilalife rederation secks to vela into a national iront all the various local clubs, and indiviauls who are interested in conservation, and then provide a neans of mass protest acainst exploitation.

This adrese nas given by the president of the Federation. It is timely and interesting. It could well be used on a senior high level to sid in understanding the social, economic, and political aspects of conservation.

"Eoverty or Conservation Your National Problem, "Darling, J. .. National .ilalife Federation; Vashington. Unated. 30 p. arnings to this nation thet the depletion of our natural resources has already reached the anger point are just as plainly mitten across the face of this continent as vere the threats nade by Hitler, ussolini, and Wironito. These marnings are uritten in rillion-ecre petches of denuded forests, abandoned rams, dust bowls, and äried-up rivers, 
springs, and lakes. Forty billion dollars have been spent but the major problem of checking the disesse of dunding resources has scarcely been touched. The war put upon our resources the greatest buraen ever known. Ce will win the war against our poreign onemies, but if we do not depend our resources we wil lose a batte from whin this continent ill never recover. If we begin now the intelligent application of rinciples which would bave prevented past vaste, we can at least insure continuity of use of whet we have left. Arerics is no richer than her remaining resources. Most of our conservation activities heve been bady overrated. Laucation is the only real road to success--te laws of nature must be observed or dire consequences will occur from their riolations.

This timely and pertinent infornation relates the effects of ar on our natural resources and consequential effects on the social and economic future of Anerica. The failure of our education institutions in teaching conservation to toschers is largely blamed for the ignonance of our people as to the present state of affairs. Certeinly this is a challenge to educators.

"ell mitten, in simple straigit-forwara language, this information is for the average laymen, and certainly for educitors.

Erice Iist of fids, The Uild Flower Preservation Society, Ino. rashington. Undeted. 4 D.

This list of aids is designed fow teachers and leaders or sponsors of clubs and organizations interested in conservation of ila flowers. Bulletins on state flowers range from 


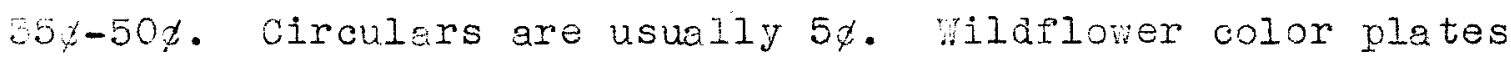
very in price. Hower posters range from 1.00 to 7.00 per 100. isual equipment (lantern slides, photographs, motion gictures) is available either on rentsl or tetail basis. This list is a very complete price list of material available from this society. Much of the material is noninal in price, and teachers could use it.

Froblens or Issues in Teacher Dducation in Arkansas, CurricuIue Labratory, College of Education, University of Arkansas, Payetteville. Bulletin No. 3. 1941. 46 p. mineo.

The State Legislature passed an act requing the teaching of nature study and conservetion in all public schools of the state. In order to prepare prospectire teachers to do cuch teaching, a tescher education seminar yas conducted to investigate and plan a colloge program to fill the need. It was agreed that the general objective of conservation education was to be the development of wholesome attitudes toward civic responsibilities through an understanding of the value of natural resources to our economic and social orders. Bpecific objectives vere concerned with subject matters. on a college level, tile prospective teacher should engage in experiences wich his pupils vill experience--organization of naterials, excursions, planning units, collecting specinens, etc. Some problens or units are suegested wherein these experiences may be net. No specific units, techniques, or procedures are included due to the limited time of the seminar. The bibliograpiy and visual aids are very full. This bulletin is a guide to college faculties in initiating a proram for pre-service teacher trainee education in 
conservation. Hhe organization of material for content is weak, due, I believe to the linited time and the fact that such a program was just beginning. It does give in insight to the problems wich have to be met.

Eublications, Michiean Department of Conservation, Division of ducation, Lansing. 1980-37. $8 \mathrm{p}$.

Listed are 106 publications issued by the Michigan Depertment of Conservation. A fev are nou out of print. some are annotated. Phe topics covered are tish, eare, stete parks, forests and lenis, forest fires, laws and enforcenent, geology, and general conservation in ichican.

This list should be helpful to teachers in gathering source material and students doing research work. The ublications are on a senior high or college level.

Aegional Eactors in National Elannins, National Besources Committee, "ashington. December 1955. 22s p. illus.

The consiaeration of what is called regional problens is thrust upon the gttention of our lvation by a number of urgent situdtions; among them are the increasinely clear realization of tre inadequacy of single states to carry out all planning programs necessary for conserving our natural wesurces, development of interstate cooperations movenents, rise of two-group-of state planning regions, creation of the 1. . A. and others. To neet problens of regional orgenizations involving more than one stete, the recomendations are (I) State plaming, (2) establishment of regional planning conmissions, (b) encourage interstate compacts, (4) use of Federal Corporete Authorities, (b) Federal Administretive 
regional centralization ( 10 or 12 ) centers. Jurisaiction is one of the most important promens of eovernmental administration. The netural resource problems are directly related to reions. Uany pro rams on a state basis exhibit inajequaies as evidenced in Iend-use and ater. Interstate compects are linited for continuous ana grogressive planning. Teaeral departmental procenures use regions as a device for ceontralization rathor than ror isolatide characteristics and problems of areas. The T. A. is the only example of a federally created regional authority. Geographic factors iaplicit in regionslism are (1) continuous and compact teritory, (s) meximum homogeneity, (o) unity and organic interrationship, (a) combric--natural unity, (5) total areal pattern of culture, (o) regional identity, and (7) iair1. Iaree size. Regional factors importanty affect such enter rises as waterways, power, irrigation, forestry, erosion control, etc.

This report discusses problens of plannin and development which overlap state lines and which reguire the use of co bined rederal and state powers. It reopentzea "state rightsit es a bie problen to we ironed out. It is a basic consideration to be consulted before regional piantive areas are designabu shu offices and vians made. To be used primerily for congressional study and action, it contains - uch for studente of evorepy, econonics, sociology, conservation eni Iave

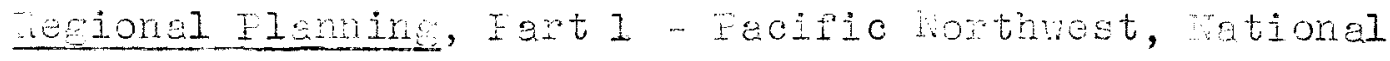
hesources comittee, ashington. ay 19:0. 122 p. illus. 
The Pacific lorthest region (Idaho, fontane, oryen, and ashireton) is primerily devoted to the production of rav materials. nanurecturing plays a minor part. This region cortains $65 \%$ of the entire virsin timoer athin the netional bondary and meintenence of the timber industry is of critieal impotance. Frivete onersin controls the lergest proportion of accessible sam-timber; few privete aper tors work on the rrinciple of sustained yield. The importance of the vater resources is aue riarily to needs of nevication, irrication and hyaroelectric levelopwent. The total developed end potential vater power resources are estimated to be sufficient to generate over $15 \%$ million killonatts of firm pover availaole $90 \%$ of the time. In we national policy will see to it that this resource is so distributed as to achieve the maximum resional and national benefits. The Columbia River is unique in creatine en ideal situation for the odevelopment. of a series of ereat power sites. "General plane" locate 10 Ereat àms. Grand Coulee anả Bomevilie are already beeun. inatoloey, vater, lano, minerals, recreation, inaus try and transportation of the region are discussed. Interregional problems re numerous. Torees mowing anainst regional cohesion are the eccnomies based on co petition between citiss, and the attituae of irrigationists tomard one another. This report gives a clear picture of the Pacific lor thvest--its physical features, its resources, and the imediate and urent problems in the Colviroia Basin. Graphe, naps, chi charts supplonent the waterial. The presentation is not techical, ana, though intenced for legislative action, woula be interesting to adults for its history, georaphy, and con- 
servation.

Regionel Flenning, Fart 2 - 3t. Lou's Region, itational Resources Co mittee, washington. June 1906. $68 \mathrm{p}$. illus.

The cities of st. Louis cnd ast St. Louis presented urent probiems in trafic, housine, recreation, and similar orenizea fielas of socis planning activities. sajoining counties into wich the central city was expanding paced special problems. The region extenas 55 miles from the central business district and is roughly $5,200 \mathrm{sg}$. mi. in area. The survey considered distribution and density of the future population, and the character of physicsl improvements needed. Recent trends show that the population is moving from the outer gortions of the region to suburban touns in the metropolitan district. The ol äer resicential aress have been losing populetion. Of the total future population, $94 \%$ is expected to be located within the netropolitan area. Fhoics imrovenents existing and proposed include highrays, briaces, elinin tion of angerous prade-crossings, airport and transit facilities, seiers, etc. Federal and interstate roblems are connected vith river navigation, port developwent and river crossings, flood control, dams, ana public health.

The problens of a metropolitan region are aifferent from those of other regions, but they are no less important. Frobeble future trends and needs of this metropolitan region are outlined and plans to meet these needs are being a eveloped. It is interesting to note the various factors influencing future trends, and the ways in which large cities change. This material is primarily for the guidence of legislative activities, 
but perte could te used in a stuay of the community oy junior him schol stuerte, or alvic clube an other such erougs.

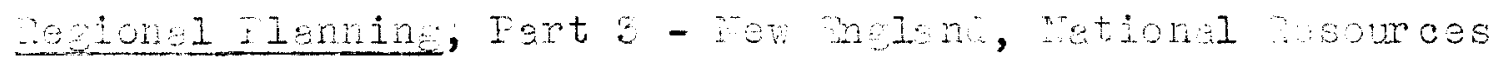
comittes, astireton. Tuly 10.6. 20 p. illus.

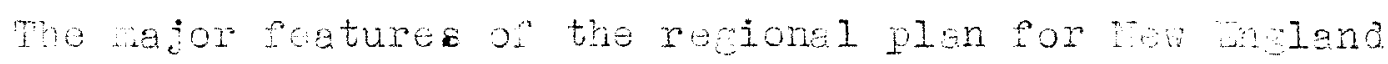
incluae: (1; e jan eur a coordintad transportation syaten;

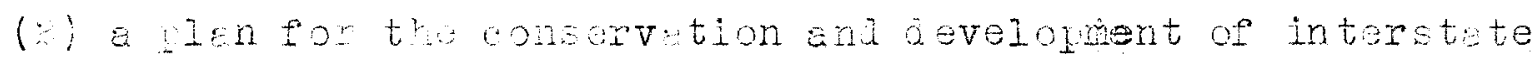
Teter resources; 16 ; a plan or the resorvtion of outetenaIns aconic and hitoricel aites, and developent tor interstate recreational ereas. Ebout three-pourths or the peple live under urban concitions; the povulation is primaily incuetriel. Aricultural problems are varkt competition, sbenconed land and erosion. Torestry rroblens are those of

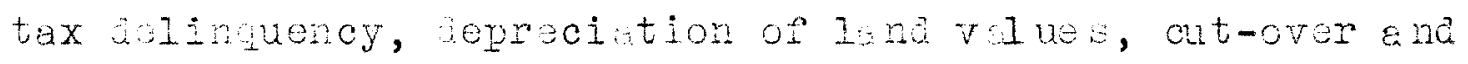

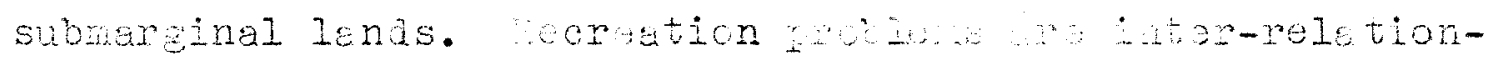
ship wotween molic end privte enterprises, pulio lend acquisition, racilitios ara acoess to recreation areas. bter pesources heve protided industrial electric power, nevieation, and ot ar onepits. Fobleme ne water suppl, po.er, polution sna flood control. Indaetries such as ficheries, non-etalic unerals and manuecturine are essentiel. The prowan oulls for a stay of conditions and prowtion of injuetrial reajuetnent nu expension. Tis arvey of Nen whiand's resources and the problems related to tho is interestingly prosented. The material re-

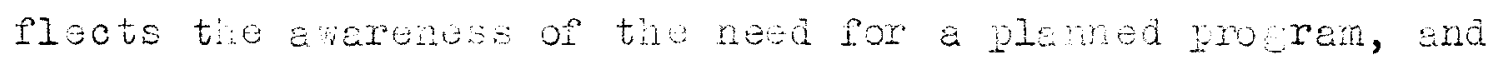
taies into consierston the separate stete fieng anj their cordination into a comi te pattern for the region. Ferts 
of the historical and eocraphicel data could be used in a comunity study by junior high school students. The maps, pictures and graphs are excellent supplenents to the written material.

resional Ianning, Part 4-Daltimore-uashington-Annapolis Area, Mryland State Flanning Comission, Jaltimore, Naryland. November 1937. 65 p. illus.

The Saltimore-rashington-Annapolis area needs a planned program to guide the growth of suburos, land use in the rural. areas, and the expansion of transportation and public utilities. Recomendations are (1) Farming--(a) riednont Section-regulation of suburban growth and preservation of open spaces, (b) Coastal Plain-purchase of erojed land for public use; (2) Suburban rowth--regulation by zoning, etc.; (b) Forests and Farks--acquire at least 100,000 acres; (4) Reservations and Institutions--preservation of taxable semi-public open spaces; (5) Notorways--construction of two najor high ays and necessary comections.

This beautifully illustrated report on the needs of the B.W.A. aree is interesting and well written. It is intended to introduce the public to the problens of the area, and to stimulate interest. If it received wide circulation, it would fulfill its purpose. The primary problem is one of suburban erouth and expansion. This report covers this problem corpletely. It could be well used by sixth graders in a study of the area; it should interest residents of the area.

Resional Ilenine, Fart 7 - Aaska--Its Resources ana Develcpments, Iational Resources Comittee, Nashington. December 
1937. $213 \mathrm{p}$. illus.

Special problems in the develoment of Alaska are (1) fluctuations of industry, (a) the native population, (b) natural resource laws and leases, (4) adinistrative agencies, and (5) insuificient public services. Alaska is inportant because of incustries based on renewabie resources such as timber, fish, or vilalife rather than because of its agricultural position. Wwo development policies are possible: (1) as s source of raw waterial for the United states (woula leave a gutted land a fev generations hence) or (E) to give it an inaependent and well-rounded economy as the physical conditions will permit. Alaska needs (I) a comprehensive survey ard investigation, (E) basic eneral plen of develophent upon wich superinposed detailed plans for each region are used, (3) a trensportation system, (4) other investications (fisheries, mining, etc.). Staff reports are given on Alaska's (I) population, (z) meteorology and climatology, (c) aquatic resources, (4) minerals, (5) millilie, (0) forests, (7) water, (8) asriculture, (9) recreation, (10) transportation, (11) communication, and (1) national desense. This is an interesting survey or Alaska--its problens, some of its resources, and the ereat need for further study and development. In non-technical languase, the naterial is vell written for interested citizens, and could be used to advantage with social stuaies and conservation classes at hish school level.

Report of the Cominitee on social and bconoric conditions in Alebaria and their Implications for Bducation, State Departinent of Education, Division of Instruction, Montgomery. Curriculum 
Eulletin iro. 3. 19:7. pg. 98-159.

the south excele in its superabundarice of natural ena humn resources and laes in the neasure of its technological wealth, its ertificial weelth, its inaustries, ma its moles of life and culture. Al bame is tjpictl. Ner use or na propit rom her rich resurees is neagr. Nor lag in technolo ical developrent is evianced by poor machinery, low-erae skills of worers, ineficint inaustries, na lack of educathon in techical Iines. Duet storns an ater heve eroded b,000,000 acres of her inds. aencies vorkine on this nejor problom are the ilabera Acrioultural ixtension orvice end the Boil Conservetion service. "wo-thirds of habang is forest iend. Fire, unise nanagment, waste, and poor wrketing

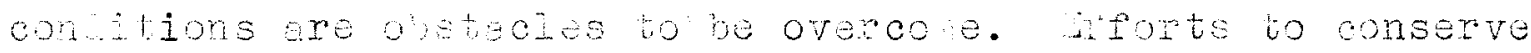
Wilife include came rofues, state omed land, hetcheries, ete. Wineral resources ilclude com, iron ore, ssphelt rook, buildine cley, ete. These nan new wealth it they are in-

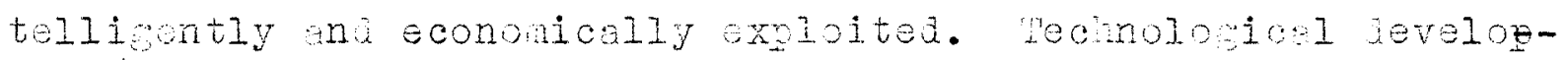
ment of ater resoures is ingerative to balance the nealth of this resource ant the compartive poverty of tile geul tion. Alabera is part of the "population reservin" ot the nation. Chilu eipere activitios are well becun. senobilitetion of the physically hndicapped, aged, ani other pheses of velfore la..

Jtilization of human resources is a besic problem for ad-

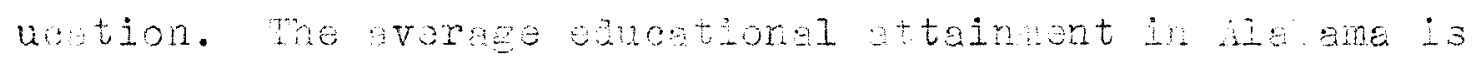

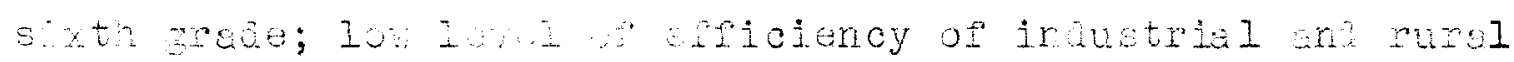
norkers is ovitent; heleria and hookrom apeect thousands; otwer petors alco five eviaence that curriculur ajeptetion, 
vocetional guidance, and recoenition of humsn needs within the state are needed.

This report deals st roet lenetr on twe region deficiences of the southeast, and Alabane in garticular. The ereat lae in al phases of sociel unu economicel asects is apgenent. The excellercies of the buth are attributed for the nost part to noture. here nen shopes his ow envilonmonthe ioture is less rosy. for al ancotore nd pople inturseled in the iuture of the south, the wlutingives a vivi gicture op the conditions there.

ovort of the beperthent of unservion, June 1s4o, lemessee Deprtant of Consorvation, anville. 1940. 48 p. Mo aivisions of the jepartent and their activities wor

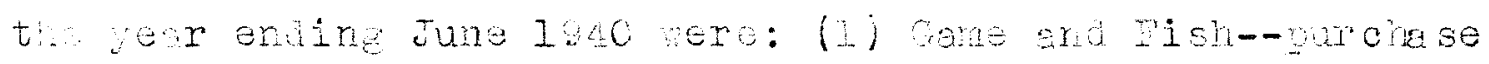
of 156 deor, an release of 1,000 tumbey, 10,000 avil, e, 400 chur portridees, operation of rour ane reserves, coperated ith A, raised und distributed IIO, wo bas and ico, 000 trout, improved hetcheries, educationel projects ith 4- Clubs, schools, and teachers. (5) Dorestry--ire control (four look-out tomers, televone lines, etc.), increased nursery areas, supplies six milion sedilnse, meinteined lessed end oned forests, copereted with united states Porestry bervice, soil conservation service, etc. (3) Geoloy-loceted ze new deposits of meneanese, reports on phosphate deposits, serias of market circulars on minerals issued,

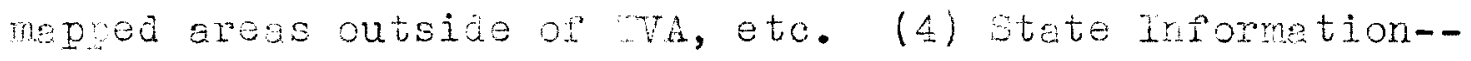
recreational end scenic booklets and maps issued, edvertisements in newsepers and magezires, mantained contacts ith travel bureaus, auto clubs, etc. (5) Hotel and Restaurant 
Incpection. (e) Bducationel service-morked ith teachers, furnished seedines cor school plentins, nowe movies, Wublished rosar and worbook "Birds o\% "Ennessee iri Verse rad song," and mede three novies, held meetinge ith civic clubs, and or anized seven sportsmen's clubs.

This pulicution eives e clear picture of the prosam carried out by the conservation Deprtment. In esci division, education is a very important phase of the work. It is of interest to citizens of penessee un to teschers as a surce material.

Resources for Victory, orchera, John a. Colurbia University Fress. Nen York. 1942. Columbia Fone Front Wrbooks Iro. 4. $36 \mathrm{p}$

we are greatiy tompted to say that our resources and their utilizetion wil irsure victory. e ere e rich mation endowed with forests, vater power, minerals, soils an other natural pealth. ith the cheree from peace to war has come a change from ebundance to scarcity. ith eli our variety of resources we heve never been self-suificient. Ve heve inoorted many thines--tin, rubber, tung oil, tungeten, nickel, vepetable oil, silk, hemp, tea, cosfee, etc. It has become increasingly difficult to obtain these materisls. To have acoumulated sous stock piles but these are not adequate to met our needs. Increasine output by speeding up production is Iimited. Development of substitutes is a Iong process. our nost important hope is to ilvert our resources from civilian consumption to ar use. Our resources, in comparison ith the position of the Axis fowers, which are aiscussed are steel, ferroalloys, aluninum, tin, copper, petroleum, crude 
rubber, rar silk and food suplies. In the revion of these resources emphasis has been put on the uneven distribution resorirce position of Germany and Japan. Gemany has steel, aluminun, machine tools and scientific knowledge; Japan has rubber, tin and fits. A diviaed stand rekes a less fomidable combination.

'his phamplet interestinely jescribes why there are shortages in civilian and wer use. It explains why civilians must do without in order to out-produce the Axis. A timely toric, it is reabeble ard easily understood by the average leyrian.

Goajs to a Ney America, Doyle, David c. Iittle, Brown and Company, Boston. 1058. pe. $3-115$.

Part one of tris book is a picture of a nation liquiating its assets--its notural resources. Cur early ancestors did Iittle damage but on expension to the lest, Anerican Iife vas keyea to the march of new pioneers uaking possession of vast and seemingly endiess riches. With the coming of technoloey demands increased and bigger and better machinery cut inroads in our supply. In a survey of our resources, soil conservation is one of the things ve are doing best in the United states. Since the oreanization of the soil conservation Service in 1954 much has been done. our country is rich in minerals and also the instruments and techniques for using up our suplies. Our forest industry is geared to juick liquidation. The Forest Service is working to oring our forests to a balance between erowtil and depletion. Civilization has usset the balance of nature and to conbat the resulting pests a proeram of wilolife restoration fits into the picture of a nation ajusting itself 
to its resources, anä trying to make them work together for our benefit. The people of America are our most important resource. Se should look to their health, morale, and training. In oraer to meet the neeas in reletion to our natural resources the author believes there shoula be closer co-operation between public authorities and privete owners, government control in sone instances, public services linted above yolitics, subsiaies to states, and ereater investnents on the part of the gomernment. The remeinder of the book deals with technology, our economic systems and goverment practices.

This discussion of Arerica's many problems offers practical sugeestions for their solution. In spite of our many mistakes the author is cheerful in his outlok. For the adult resaer the book is a challenging survey of business problons in a democracy.

Should re Fave National Textbooks on Conservation Teaching? uaintance, Chas. H. School Science and Tathematics. October 1938. PP. $799-795$.

Surplus aerived from the sale of wilalite poster stamps during National "ildife kestoration vek, said "Ding" Darling, should be used for national tertbooks on conservation. But, would national textbooks be advisable? Local conditions differ. A textbook mitten for one state or area would not be adequate for others. The diverse regions of our united states have many major resources; any textboos to cover these mould be enormous. $A^{n}$ investiestion of state tentative programs nas carried out. Sone gave evidence that the material being aiven to teachers has a teriency to injoctrinate current practices rether than clear critical thinking. Whe study of things at hand shoula 
be stressed. Furthermore, buildine on personel experiences With local resources, the child can create a philosophy of conservation for his on community. A textbook describing seneral orincirles and problems canrot have the effect that actual contact will have. Weture students should be conversant on problens of broad scope, but this knowledge must have a basis laia on a stuay of familiar resources in the immediate environnent.

This article clearly recoenizes the definite leck of textbooks on conservation. The advisability of national textbooks is auestioned. This article would be of value to teachers and curriculum planners.

Social studies, (Secondary school series), rissouri Iublic School Currioulur, Burletin AL. 1941. pp. 97-108; 891697;45I-470. Tefferson Uity.

This is a course of etuly designed for use in social studies ith preases $9,10,11$ and 12 . In the section on personal and commity problems Tnit $\gamma$ deals . ith the citizen's opportunities and oblieations in relation to his physical environment. "he scope of the unit covers the resources of vissouri ard the problons involvod in their use and conservation. Ir the section on contemporary Anerican problums, Init $\forall$ is concemed ith conserving human resources as a social problem. The scope of this unit covers the worker (health, sarety, hapeiness, competition with mechines, trainingl ena emioyment problems. In economic problems, Init $1 \mathrm{~V}$ and $V$ are concerned with pases of conservition of soil, foreste, mater, minerels, wilalife, and their influence on man's way of Iiving. The agencies workine to ard conservatin of our 
resources are included in the unit. The unit on acriculatural problene some whet overlars, but is considered so vitel that i.t. is included.

For each unit an extansive biblioeraph, op books, phumpets, wazines and goverment publications is iven. riavel aijs are Iisted for sme units. The susested activities ore reried are morthohile. pese units are based on comunity problems cheracteristic of issouri and should be nost helrful to terchers.

Fegenin Conservetion in lenentary chools, athurst, wiie G. Unitea dates ofice of ducation. hesington. 1940. I85 P. (Sulletin 1958, No. 14)

This buletin aegs with the oreanization of material concerning conservation and wys of teaching. Conservetion eiucation canot be confined to any one subject nor linited to a srele unit. Aiv gin op outine of content should be rexible enough to allow ajustments to needs of classes and unforeseen saterets. The or ganization of aterial should afford opportunities for the integration of instruction with nonal activities of life, and activities of different arades should be cordinated with respect to the interests of the entire Group. sech school must plan its own type procram. Mven is a sugestive outline for use in developing units on conservation of soil. It is aiviaed into oringry, interrediete, and avroed notorial to be used in either urban or rural comunitiss.

The activities given nay be ueed to a avantage by toechers developing units on soil and land use. The organization of the material is somenhet veak but parts can be used. The anotated 
bibliography for teachers and purils is erceilent.

This bulletin woula probebly oe most useful to a comittee on curriculum developient.

Teachine Conservation in isconsin Gchool, .isconsh verartuent of rubic Inatruction, adison. Curpiculun EuILetin Jol. I, 10. 1. ay 1957. 63 p. illus.

Conservation seek to atatein the supply en uality of our netural resources. Conservation is one of the najor ays

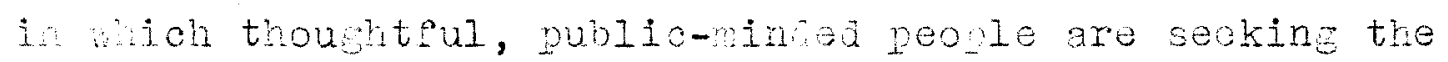
comon good. e reve sroups of interested indiviads mo are endeavoring to arouse the pubic to some unierstanding of the factors involved in the conservetion of our resources. e heve pried repulation. ou society has turnea to the scion.

In the preschool years the child wa be tauble to respect the rishts of othus, and to have a foeling ior the beanty of nature. In the elenentar years conservetion attitudes and epprecietions may be much extended end strenethened by nature study. In the grly secondary years come basic prirciples mey be grasped; in later years these will be extended to incluae the social and economic aspects.

In aisconsin schools the resources considered are soil, water, minerals, forests, ilalife, and scenic and historic ites. An outline of content is given por each resource; the bibliograph is shoit. ach teacher would necessarily select naterial for her on needs. lo procebures are eiven, but $a s$ a guide por subject material this neterial is excellent. 
Its History, Government, Industries and Resources, ashington Department of Eublic Instruction, Olynpia. September 1941. $28 \mathrm{p}$

This unit is to be used in the intermediate grades and mach opportunity is evident for a study of conservation problens in relation to industries (Iumbering cra forestry, farming, fishing, etc.) and in a study of scenic and historic sites of the state. The activitios are not particularly numerous and very few books or other informtional material is aiven. Howover, the outline of content noterial is well oreanized. It coula be used by teachers of the state of ashington.

Tentative, Suggestive outline for the study of ashington-Its istory, government, Industries, and kesources, askington Departnert of Fublic Instruction. Olympia. September Is4l. be $\mathrm{p}$

In this bulletin two units are developed on conservation --one on the lumber industry of Everett (mills and mill products), and the other on the industries and resolirces of the State of ashington and the Facific lorthwest.

In these two units, on the ninth grade level, the outline of content is well organized; the biblioraphy is excellent; sliaes and film strips are listed; the suggestions on procedures are full. This is excellent as a guide for constructing units to fill particular needs and abilities.

The Advance of Conservation, Thergency Conservation co nittee (report for 1937), New York City. Pub. No. 70. 1987. 12 9. Described in this report are the efforts put forth for 
the saving oi the Iosemite Sugar Pines, the campaign for the 0lymphic Forests, the operation of Hawk Nountain banctuary (filn made), demands for a closed season on materfowl, protests gainst Fennsy vania's bounty of 2.00 on the Great Horned OwI, and the publications of the cormittee lunits on Owls and Tawks, at high school and college level).

This report serves to inform the public of the activities under way. The interests of the comittee are widespread, en mere canpaiens are peesible, it sends representetives to plead the cause.

The conservation of iratural Resources, (Digest of subcomittee Report). Department of education, Comittee on Curriculum Evision. Baltimore. 1940. (Report Mo. 7) 282 p.

This builetin is a prelinin ry stuy wich considers the essential facts of the rroblem of conservation as it afrects such topics as soil, waterways, forests, nila aninals, minerals, hoalth, state and national planing. rhis stuíy will be the basis for formulatine and revising courses of study (in Maryland) to reet current social and econoric neeas. The topics covered as to causes, control, acencies, and econonic effects are soil erosion, fam lanus, water resources, forests, wildlife, ninerals, human resources, and netional, state and local planning. With esch topic are listed the educational implications which vill be the guiding principles underlying the building of courses of stuay. In view of the fact that a variety of subject matter is already offred in the curriculum, it is considered advisable to emThasize conservation wherever possible in the existine courses of study in sociel study, Brglish, and science. Illistrations 
of such emphasis are described in civics, geography, eneral science, biology and econonic civics.

This bulletin would be of valuable aid to croups revising courses of stuay and as a guide to individual teachers in orenizing units ond projects concerned with any phese of conservetion. Ferts may be used ith fifth on sixth crade croups as source material for oral reports ana the like. The biblioeraphy for each toric is ercellent por teacher use. the conony of ibunance, Chase, stuart. The acnillen compeng. lien rork City. 1954. $202 \mathrm{p}$. The Economy of Abunance means an econonic condition where an abuncance of material goods can be producea for the entire poulation of a iven comuntty. Our conditionine has been in terms of scarcity with enphasis on the vendibility of goods rather thai seviceabiity. Scientific mothods laid the foundation for the econony of abuidance which arpeared late in the machine age. ouch a conaition functions only when industrial units operate at capacity. Capitalism functions on a vendibility basis. Fonopoly, protective tariffs, logding of distribution costs, suppression of invention and other mans are used to maintain a spurious scarcity. The economy of ebundance is undemining the efforts of benkers and manufacturers to preserve the scarcity values of their connaities. In spite of the poet increase in enerey output there has been no corresponing increase in the material velbeing of our popul tion. rood, clothing, shelter, education, health, and recreation are still within tho province of venjibility, and probl sms of economic insecurity lacing the 
camer, mechenic, day laborer, clerk, etc. are identical. our country has ereat wealth in natural resources, poner, ma enerey, but not in terms of humen use end enjoyment. mis inventory of our resources of enerey, services, ori zoons suons the advance in welloeine thut might be obtained it these resources vere pernitted to be used in our benlf. Drastia chanes in our econonic system pould be necossery, but no nention of how to nke the chanee nor the inel cos to be attained is given.

Por the Ioymen and college student tris book presents sotual noterial in a jotureague and interustine poro.

We Structure of the Anerican Sconoury fart 1 Jasic Character-

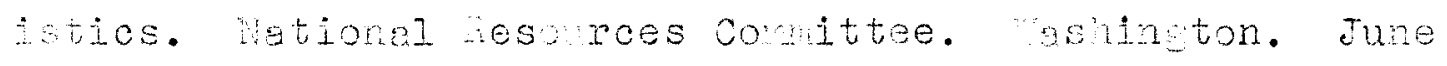
I95\%. 1\%.

Te najor bosicelaents in the structure of economy are the ants of the consuner arit the resources of the ountry. oncrete posurces are the natural resources and the pient develogea by nan (holes, fectories, etc.i. Tese nawural alla man-maje impovenents provide the physios resources avaiable for further groduction and contribute to the structure of Arerican econom, pricularly the coorapical charectepistics. other resources which condition production are clime te and toporaphy, tocmigues of grotuction end

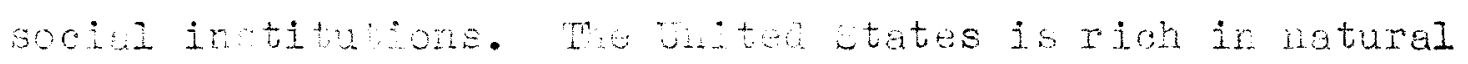
rowurces; we are eseantially inaepenafnt of foreign resources. wo wouctive glent is weli constrotea and flexinle. The pigeical environment is axtremely ravor ble sor production. Our techolog ie mojern ana effective. a beve a complex of social institutions wich binds the whole poulation into a 
vunctioning econony. It is not lor lack of consunable resources that consumer ants are not nore fully end extensiveIy eatisjed. Deulty oreanization of production is the case. Tie eorepical atructure op merican econod lezlects three pactors: location of Iesources, iocetion of consumers, an the intorios procese by nich economic activity as beer carried on in the pest. Trauetries located close to

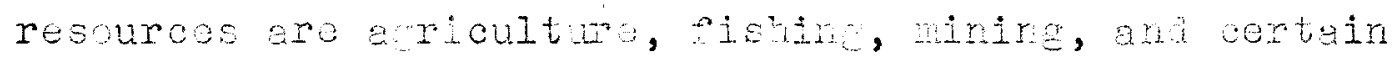
menurecturire rocessos. Inusstries related to sovices, reteil traje and construction are loosted olose to coneumers. Rolotively foot one actuities res those of the rolesale traje und certain other nenuacturine procenses. Tis estion is conemed with the extut to hah the

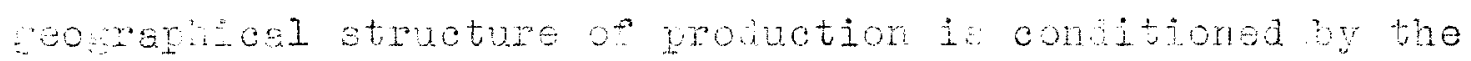
recosity ot cempine on eome activities alne to pertionir mesources and others in olose roxinity to connues. It inicetes also the sooureos oi the Unitod tates and their grt in therican economy. Mis neterial serves to mee more concrete the majola activity of the milions of persons who conge the merioen econoy - Tuis report ais in understandin the basio netionel probien of unentoyea resourese and should interest, perticularly, students or economics and conservation.

Tre study of concervtion, miennich, ceore . Mmesota beratrent of ducation an conservtion. et. Pau. 1040. E.

During tie pest ten Joas the public has becone interested in conservation. Stote depertments ef education are Iaring the founjetion and school authorities are beginning 
to offer it as a pert of the curiculum. The stuay might be intersted in the reuls courses if all teacher were acqueinted ith the essential philosony and factul back round. since this is not the case, it is not now suviscble to linit conservetion to the inciaentsl treatnent it can receive in connection with other subjects.

Conservetion is detined as tho study and prectice of wise utilization of resources to the end tist the ereatest number of peonle may be served best. The echisement of conservation is dependent ugon education and social attitude. A compehensive prosen meses use of four methods: restriction, restorstion, proauction and distribution. sesources of innesota wich are discussed are minersis, weter, soll, forests, ilulife, and humen conservetion. part 1 of the phemplet deals with the problems of conservetion ane their influences on socis and cononic progress. Fert 11 is an outinne of subjective reterial. Intended ror junior end senior hich level, the cuestions for study and activities are exclient. The bibliograpy is full and up-to-iste. woh of the meterial is adaptable as textboor material, and makes much use of environnent situations. is a guide for innesota teachers, the phemplet should be most helpul.

The Teacher Looks at Conservation, Tink, 0. T. J. vision op Conservation and Naturs Resources lin cooperaticn ith state Departrent of aucation), coluwbus, chio. reviaed Jonuery 194z. 05 p. illus. Ohio, in 194 , was initiating a conservation education project and this bulletin tor unio teachers as issued to 
accuaint trem ith the need for such a prosem, end five some icea of the direction the progran would teke. In a simole snd non-scientifie way, the gererel problens of conservation of ristural resources, ater snd erosion, lanu use, health, an viues. He report includes sugestions tor activities mich may be appted to verious erade levels (expriments, collections, exhibits, excurstons, etc.l.

The rateriel is not in unit form, but is intenod to aid toachers in begining conservation studies. Whe bibliog$r$ pry is concernet ith bevelonin conservetion attitude.

The bulletin would be of use to any person who ants a enerel overviev of the problems in conservation an treir eolution through educstion.

Third iennial aeport, (1955-1906) insesota Departnent of Conservtion, st. Jaul. Jecenber 1956. 500 p. ilius. me reporte aiven by the various sivisions of the depertment are: (1) Jrainage and aters-invosiegtions and surveys mede, morked wth etate anj pederal agencies on control structures and neasures of soil erosion, tile drain repairs, etc.; (b) Forosts-expanded and improved dtote ursery, forest inventory and fire protection neảe, Christmas tree industry supervisea, st te timber sola, lectures, exhibits, novies shom; (3) Gane and Fioh--fich propaction t hetcheries, removed rough fish, ruses estrolished and improved, supervisea trapping activities, caried on research in vilalife food, aisaese, etc.; (4) Lanas and inerals-research stujes made, issued rasture pernited, licenses iscued, etc.; (5) State Furks-arintenance, operation, ana inprovenent of state 
proks, presented ten historical pazeants each year, completed four reels of souna movies, issued phamplets on facilities of parks.

This report describes the accomplishments and future gians of the Conservation Department of Finnesota. In all divisions, education of the rublic is strcssed. It should be of interest an aid to other states.

Dirteenth Diennial geport, (I836-1:27) Depertwent of conservation, rew orloans. 1838. 487 p. illus.

The function of the Departnent is to conserve the natural resources of the stete so thet there will be a minimum of waste, and to foster and encourace protection of vildife. The nost important fur-beaser is the muskret. A description of its habits, traping nethols and also of the ovossum, recoon and mink is given. The wilalife sanctuaries of the stete ere the morld's larest. Construction of guail, phosant and turkey hatcheries is in process. One jivision of the department ie concerned with oyster beds. Me Geological Survey is concerned ith reports an investietions of round veter resources. Minerals are described in each rarish were they occur. Iikewise, the sulphur and selt-dones are aiscussed. The Division of Forestry has $6,200,000$ acres of forest land fully stocked inth nev tincer, and advises and consults ith landoners on propor cuttire nethods end development on a selp-sustoined yiela. Frevention of forest fires is the reatost problem. Whe Bureau of soientifie rescerch end totiotics conduets sea and river shrime etudies, rollution studies, oyster investietions, compiles data, and answers immunerabe incuirios. Bacetional proprams include (I) intro- 
duction of textbooks on conservation in public schools, (E) expen ine ana noderrizine motion picture service, (z) museum services, (4) Iecture services, and (5) exibits.

Th is bulletin presents e very full and pavorabie acount of the proprem cerried out by the conservaton opertuent of Louisiana. The pictures are excellent. The veterial, for the nost pert, is on e sixth grebe peadine $10 \mathrm{rel}$. warts could be used in a stuay of fur-bearing enimals, preparation of pets, tie oyster ant shrimp industries. Te buletin reks root interesting roaing.

is Is Cur Land, Choyney, J. G. en Siantz-ansen, I. .ebb wulishing ompan, ot. Faul. 1940. Sal p. illus.

our Iari is a country of rebulous riches in soin, ater, Ponsts, erasss, ilalife, gno ninomals. mose natural nesource alded one another in an intricete gettern called

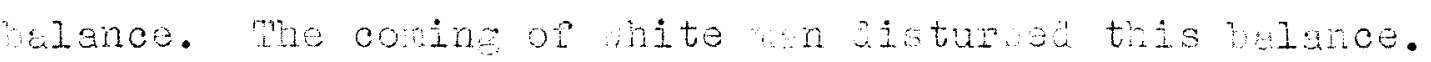
In is effopt to estabish nomes, ecuire dith, baild roads, etc. man exploited the rrited tetses on the assumption that the ricies ome inerisutibie. hout 1900 the nation bean to take note of its mistakes. Gided by Iecaers such as Giford linchot ma meodore Boosovelt, the conservotion movoment cane into beins. In general, the aour principles of conservetion are ise use, re-use, bost use, and plenned use. ith these princinles in nind, the resources ere on-

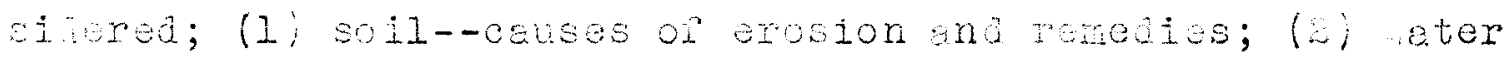
- -nisuse and boat use; (2) foreste- seto, best uses; (4) erass-as a soll binder ena as a fouk bupol; (b) wilalireroasms for iecine an 1 ans of pestoration; (s) ninerals-caroful use, better procesing, subtitutions, etc.; 17) 
human resources--social health, eduodion, recroetion, en$10.2 \ldots+2$

This is a picture of tie present extent, value, and curreat statis of the nation's natural rosources. Hon these resures have been used on whet shoula be done to take croper care of them in the future is described. He bok is interestingly rituen in ron-techical torms, an is generousIy supplied wth exculant potoraphe. pitten prinarily as a text in conesration for ij school students, it also suppies infonetion fop the eneral reader.

Units in conservition os ilulice end other datural resources, Gilpin, T. J. Kentucky auodion Bulletin Tol. O, No. 6. renkfort. Aueuet 1941. Do. B-75.

This course of etujy give unite for erajes one through trolve on conservation in Rentuciy. It uses the schol erounds, comunitias and cams as potans for the projects. The units on enimal, bird ad plant frionds and on soil,

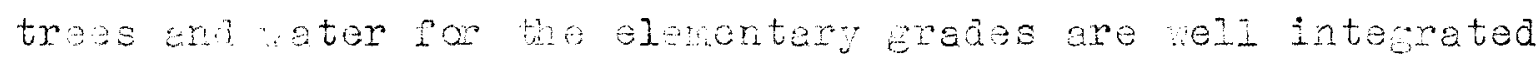
with al1 basic subjects. The units on voctional cuidance in a ioultural poblens of consorvation of a il, forests, fish, and aro conta pon helpiul reterial for tre teacher. Given ere a check-liet of biras, wictures and descrip-

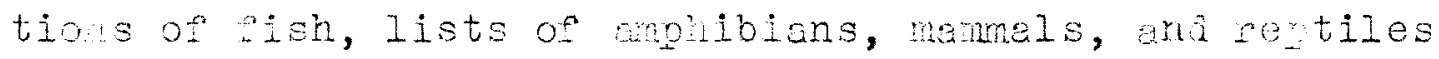
Knon to jocur in Tontucky, forest treos of Tontucky, and a bach sion of Tentucky tiste Farks.

The mits are compete with opetives, activities and stulutions and source noteriel clearly defined. I blieve they mould ne mone relprul if visus aids (movies, lanternsides, film-strips, etc.) vere listed, especially for the 
lover ziraes.

The course of stuay is to be used by tewchers.

Visualizing Conservation, Garien Club of Aserios, Conservation Comittee, rev rork City. Unated. : p.

Interest in noture is arousea though personel contact ith it. ays in wich arjen clubs may cooperate ith schools and other roups ere iren. mese include sponsoring contests for conservation posters, fumish veterial (aubiuis, terrariums, ibrary naterials) tor school neture - rocks or clubs, eive lectures with Iantern silies or novies, sponsor exhibits and a isplays, perticipate in observance of Conservation veek, Arbor Day, eto.

This suggestive outine aint vell be followed by any civic sroup in the advancenent and avelopment of conservation.

Wether, Astronomy an keteorology, Unitea states Goverment Erinting office, superintendent of Documerts, ashington. Erice Iist 43 - End eaition. Arril 1940. $15 \mathrm{p}$.

This is a Iist of covernent publications mich are svilable on tie above subjects. wuch of the terial is on high school level, but some of the phamplets, especialy on floos an flooj control, ient be used at lowar levels. orla Pesources nd Inguetries, Zimermenn, Wrich W.. Virper ana Tros. New Tonk City. 19.3. Osa p. illus.

hesources are inseparbie rom man and his ants; aterials become resurces only if, when, na in so iar as thay are carable of servine man's need. Tariety of resources reflects not only aiferences in natural enviromonts but siso functional differ- 
ences in forns of civilizations. As a result of changes in supply and denand conditions, aericulture has lost the position of ominance it once held. The difierences between vegetal and rachine civilizations are stressea. Agriculture is a composite of many economic activities, nodes of living, and social functions. The important aspects covered are food resources, tree crops, and forests. The mojern rachine civilization depends upon the supply of mineral resourees. The chenical inaustry rests solialy on the basis of modern science. Supplementation of the netural supply of raw naterials by supplies fron the test tube, vaste pile, and junk heap has far reaching importance.

In Iurope, conservation has long been accepted. Theodore Toosevelt aroused sreet enthusiasm in Ameica, but fer tareible and far reaching effects resulted. Conservation has become a business proposition concerned ith oil, forest, vater, and land resources. The vorla has becone a resource hierarchy. The united st tes is extrenely fortunate because of her economic youth and the larse size of her total reserves.

This detailed account of world resources end industries is a study of the physical basis on winch the suructure of price econony rests. The fielas of natural sciences, technology, and human, sociel, cultural and economic georaphy ere fully explored. It eives the stujent an amareness and apprecietion of the nature of our monern machine civilizetion, and the interaepenjence of nations. hrouehout, enphasis is placed on functional relationsips.

This meterial is for college students in courses of economics, worla geography, ana conservation. 